MOTICE

PORTIONS OF THIS REPORT ARE ILLEGIBLE.

it has been reprodiced from the best available copy to permil the broadest poesible avallability. -
Dist. Category UC-66

\title{
GEOTHERMAL PROGRESS MONITOR REPORT NO. 6 June 1982
}

\author{
U.S. Department of Energy \\ Assistant Secretary for Conservation \\ and Renewable Energy \\ Division of Geothermal Energy \\ Washington, D.C. 20461
}

Prepared in Cooperation With the Interagency Geothermal Coordinating Council With The Assistance of

The Mitre Corporation, McLean, Virginia 


\section{DISCLAIMER}

This report was prepared as an account of work sponsored by an agency of the United States Government. Neither the United States Government nor any agency Thereof, nor any of their employees, makes any warranty, express or implied, or assumes any legal liability or responsibility for the accuracy, completeness, or usefulness of any information, apparatus, product, or process disclosed, or represents that its use would not infringe privately owned rights. Reference herein to any specific commercial product, process, or service by trade name, trademark, manufacturer, or otherwise does not necessarily constitute or imply its endorsement, recommendation, or favoring by the United States Government or any agency thereof. The views and opinions of authors expressed herein do not necessarily state or reflect those of the United States Government or any agency thereof. 


\section{PREFACE}

The Geothermal Progress Monitor Report is published periodically and disseminated within the federal government and to mafor DOE contractors and others who need current information on geothermal energy development. The report provides information on status changes and the overall rate of progress in the development of U.S. geothermal resources. These changes are reported to and observed by the Geothermal Progress Monitor (GPM) System.

The primary purpose of the GPM System is to monitor and report activities in the geothermal industry in order to assist the Division of Geothermal Energy and other member agencies of the Interagency Geothermal Coordinating Council (IGCC) in determining R $\$ D$ priorities.

The principal objectives of the GPM System are to:

1) provide a single point of reference on a national basis for the status of the various geothermal activities, especially R\&D directed at solution of recognized technical problems;

2) identify significant trends in these activities; and

3) report events that may have significant impact on the course of these activities.

The reports focus on two types of information:

- Status - the baseline of how much energy is being produced from geothermal sources and the level of activity being pursued to increase production.

- Trends - changes that occur with respect to the baseline information and the possible significance in each report.

Each of these types of information is addressed, as appropriate, in the separate subject sections listed in the Table of Contents, with the Executive Summary providing a quick highlighting of the new information in each report.

The overall objective of this report is usefulness. The only way to determine its usefulness is by response from its recipients and users. Therefore comments on any aspect of the contents or presentation are encouraged. All comments and contributions will be given serious consideration, even though staff or schedule limitations may preclude their immediate incorporation into the current report. For any contributions, please include a name and address or phone number for follow-up or further information.

These GPM Reports are part of an interactive process, whereby contributions from DOE Headquarters and the field will shape the contents of the reports. Continuing input is needed regarding types of information or analyses that would be of use to recipients.

All IGCC participants are requested to submit items of interest, particularly:

1) changes in policy or regulations, both final and pending;

2) important events in the field, with a comment on the possible significance of the event; and

3) brief data summaries or statistics that may clarify status or indicate trends.

All comments or contributions are welcome. Please address them to:

Geothermal and Hydropower Technologies Division

$C E-324$

Forrestal Building - DOE

1000 Independence Ave. S.W.

Washington,D.C. 20585 


\section{DISCLAIMER}

Portions of this document may be illegible in electronic image products. Images are produced from the best available original document. 
I. STATE STATUS SUMMARIES

Alaska

Arizona

California

Colorado

Hawai1

Idaho

Montana

Nevada

New Mexico

North Dakota

Oregon

South Dakota

Texas

Utah

Washington

Wyoming

II. RECENT MAJOR ACTIVITIES (GENERAL)

III. REPORTS AND PUBLICATIONS

IV. DIRECTORY 


\section{FOREWORD}

Geothermal Progress Monitor Report No. 6 presents a state-by-state summary of the status of geothermal leasing, exploration, and development in major physlographic regions where geothermal resource potential has been identifled. Recent state-specific activities are reported at the end of each state status report, while recent activities of a more general nature are summarized briefly in Part II of the report. The report also includes a list of recent publications of potential interest to the geothermal community and a directory of contributors to the geothermal progress monitoring system. 


\section{STATE STATUS SUMMARIES}

This section is a state-by-state summary of the status of geothermal leasing, exploration, and development in major physiographic regions where significant geothermal resource potential has been identified.

For the purposes of this summary, resource potential is based on criteria of measured temperature, depth of existing producible wells, and existence of significant electric power or direct heat development. The sites surveyed in this report were selected according to one or more of the following criteria:

- estimated reservoir temperature of $150^{\circ} \mathrm{C}$ or higher;

- existence of one or more producible deep (2000 feet or greater) geothermal wells; and

- significant potential for direct heat applications, as evidenced by existing projects or interest shown by prospective users in developing such applications.

Each of the sixteen state summaries consists of a general overview of the state with a map showing the locations of identified geothermal resource areas within the boundaries of specific physiographic regions; status tables showing leasing, exploration and development activities; and a narrative section detailing status information outlined in the tables. Each state summary concludes with a list of recent activities or actions of statewide interest. Recent activities of a more general nature are summarized briefly in Part II of this report.

The first table of each state section presents federal lands leasing and exploration which have taken place in each of the major regions. Leases are shown as acreage held by each company involved in geothermal activities in a given region and by private individuals in the aggregate. Deep wells are defined as those wells of greater than 2000 feet in depth. Though each region identified in the tables is broken down into sites or areas, developers' leased acreage or drilled wells generally reflect regional rather than site-specific activity.

The second table presents actual development activity, if any, which has taken place in a region. Development activity refers to power plants or direct heat projects which are in operation, under construction, or proposed, including those which are in the feasibility study stage. Real or projected dates for project operation are shown in the last column. For electric power plants, the utility which will buy the geothermal power from the field developer is indicated. In the case of California, electric power development at The Geysers is shown in a third and separate table.

\section{ALASKA}

Alaska's low and moderate temperature geothermal resources are being used in a few direct heat applications. The Alaska legislature recently passed a law defining geothermal resources.

\section{Leasing and Exploration}

Four areas in Alaska have been identified as having significant geothermal resource potential. The locations of these areas are shown in the map in Figure 1. There are no federal leases and no completed, deep producible wells in these areas.

\section{Direct Heat Applications}

James Dykes of Bill Island Hot Springs has used geothermal energy for space and process heating applications since 1900 . On Adak Island, a military base is pursuing a commercial district heating development. The project, which is receiving partial state funding, will extract geothermal energy from a $3000 \mathrm{~F}$ reservoir. Direct use projects are detailed in Table 1.

\section{ARIZONA}

The Arizona resource is in the low- to moderate-temperature range. The state is exploring ways to increase use of these resources; the state legislature is currently working on defining geothermal resources and thus improving their legal status. 


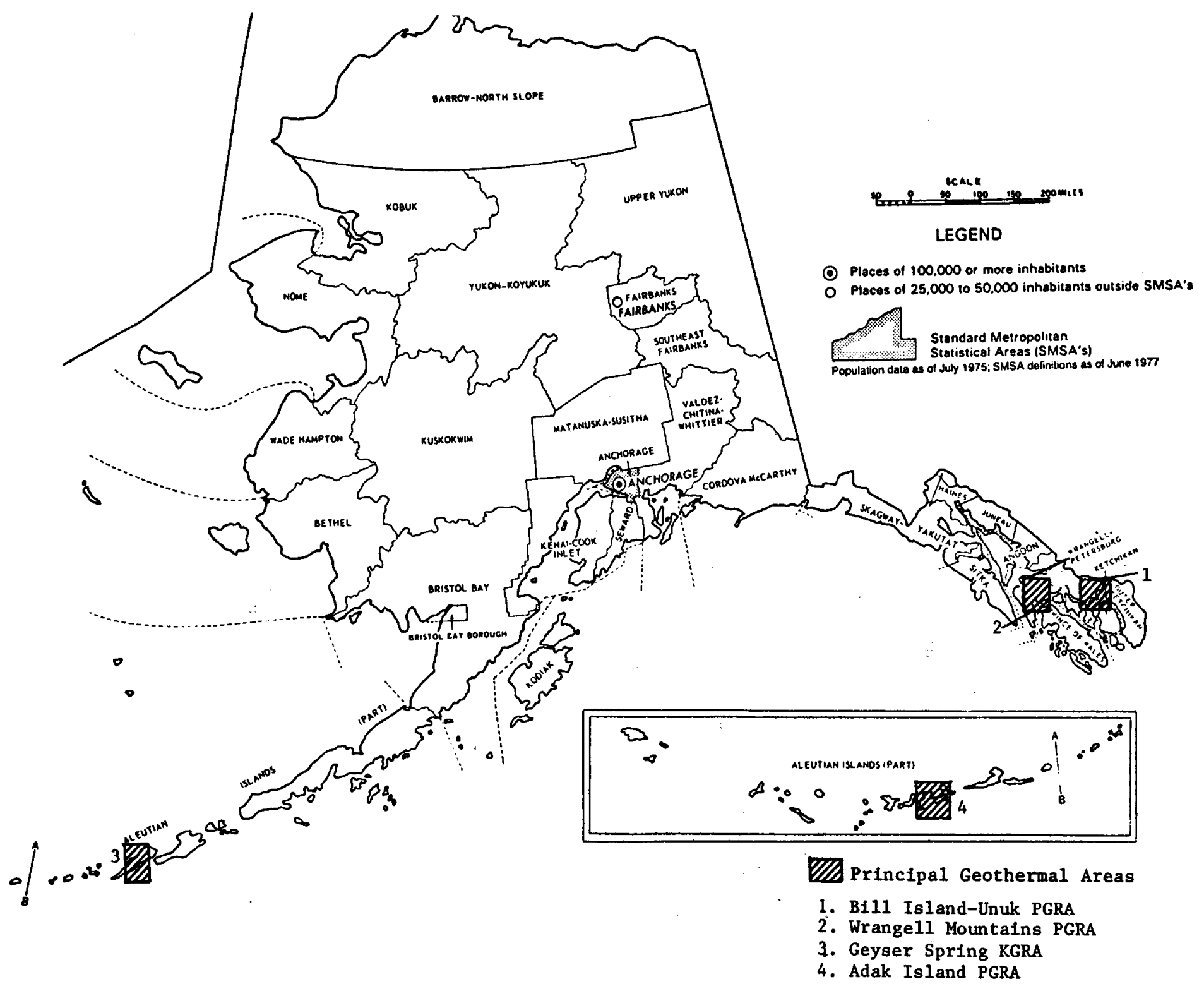


TABLE 1

Code: UC" ${ }^{\#}$ - Under Construction

PR - Proposed

OP - Operating

ELECTRIC POWER AND DIRECT USE DEVELOPMENT ACTIVITY

$U$ - Unknown

\begin{tabular}{|c|c|c|c|c|c|c|c|}
\hline REGION & $\begin{array}{l}\text { AREAS / SITES } \\
\text { INCLUDED }\end{array}$ & DEVELOPER & UTILITY & STATUS & MWe & $\begin{array}{l}\text { ANNUAL } \\
\text { BTU } \\
\text { EQUIV } \\
\left(\times 10^{9}\right)\end{array}$ & $\begin{array}{c}\text { YEAR ON-LINE/ } \\
\text { OPERATIONAL }\end{array}$ \\
\hline ALEUTIAN & Adak Island PGRA & Military Base & - & PR & - & $5 *$ & $U$ \\
\hline COAST MOUNTAINS & $\begin{array}{c}\text { Bill Island - } \\
\text { Unuk PGRA/ } \\
\text { Bailey Bay H.S. }\end{array}$ & James Dykes & - & OP & - & 8 & 1900 \\
\hline
\end{tabular}

*Annual energy use is a rough estimate.

\#For direct heat projects, construction begins with preliminary development activities such as exploratory drilling. 
The three areas in Arizona which have been identified as having significant geothermal potential are shown in F1gure 2. A total of three deep, producible we11s have been completed in these areas and there are no active federal leases. More detafled information is given in Table 2.

\section{Direct Heat Applications}

Arizona's geothermal resources in the areas defined as having the greatest potential have not yet been used in heating projects, but exploratory drilling has begun at Williams Air Force Base near Chandler for a resource to heat and cool 40 buildings. An Industrial process heat project is proposed for the same area. More information is shown in Table 3.

\section{Recent Major Activities}

\section{- Legal Status of Geothermal Resources Needs Clarifying}

Amendments to Arizona law concerning the use of ground water under $350^{\circ} \mathrm{F}$ are being considered by a legislative subcommittee working with the National Conference of State Legislatures (NCSL) and the Arlzona State Geothermal Commercialization Team. According to the team, Arizona's new ground water act needs to be amended to clarify the difference between a geothermal resource and a ground water resource. Hot water at temperatures below $350^{\circ} \mathrm{F}$, suitable for direct heat applications, is avallable at many locations throughout the state but the law is not specific on how one would obtain permission to use this resource. The state law is not explicit on whether geothermal water is covered by the ground water act.

$$
\text { Source: GRC Bulletin, 4/81 }
$$

\section{- Williams Air Force Base, Ar1zona Considers Geothermal Direct Heat Use}

Williams Alr Force Base, situated near Chandler, Arlzona may use geothermal energy to provide 3,320 tons of air conditioning for 40 non-residential bulldings. The U.S. Afr Force and Department of Energy are jointly funding exploratory well drilling at the base.

$$
\text { Source: Phoenix, Repub1ic, Phoen1x, AZ, 2/20/81. }
$$

\section{- Final EA Completed for Gila Box Area}

The Safford District, Bureau of Land Management has completed a final environmental assessment of the Geothermal Resources Leasing Proposal for the Gila Box Area, which 11 es between Safford and Clifton along the Gila River.

The proposal, according to Fritz U. Rennebaum, Safford district manager, is to allow leasing of the 181,000 acre area for geothermal exploration. The environmental assessment addresses only the inttial exploration stages of resource development, since the true geothermal potential of the area is relatively unknown.

Phillips Petroleum has made nine separate applications for geothermal leases in the Gila Box area. If exploration discovers a viable geothermal resource then the lessee may apply to continue exploration and development.

Source: Eastern Artzona Courter, 2/11/81

Graham County Guard1an, 2/11/81

\section{CALIFORNIA}

California leads the nation in geothermal energy development. The two main factors contributing to this leadership are the state's commitment to developing alternative energy resources and the existence of an abundant geothermal resource at The Geysers steam fleld, one of the best such fields in the world.

The geothermal energy scene in California is dominated by electric development and production at The Geysers field and electric development activities in the Salton Trough/Imperial Valley area. Direct use projects have recelved less attention. The existing installations are concentrated in the Lassen area, but Industry has shown interest in using Salton/Imperial geothermal fluid for direct applications.

Developments at The Geysers have succeeded to the point where institutional issues common to large development projects now tend to dominate the news. These include disputes over environmental 


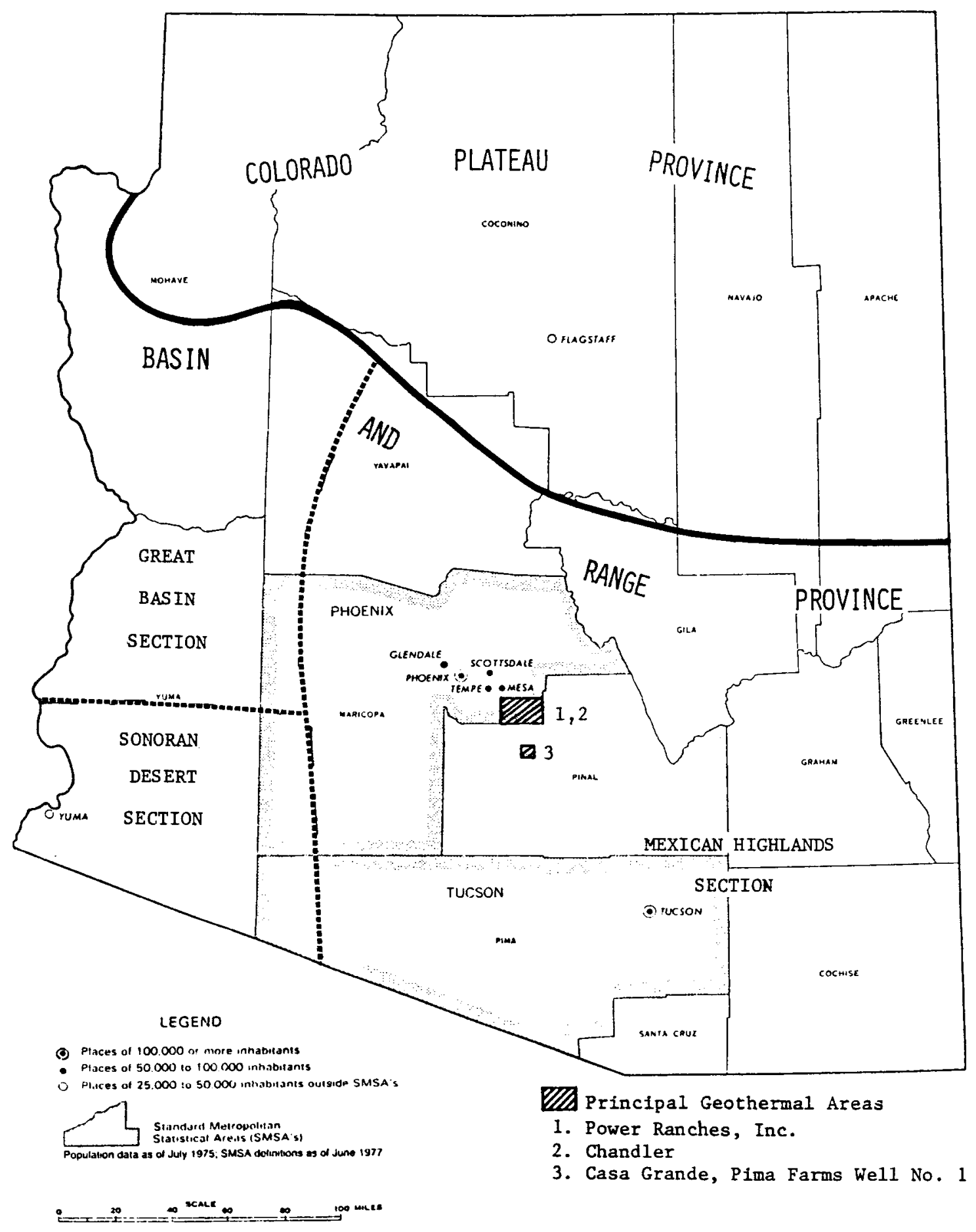

Figure 2

Principal Geothermal Resource Areas in Arizona 
STATE: ARIZONA

TABLE 2

LANDS LEASED AND/OR EXPLORED

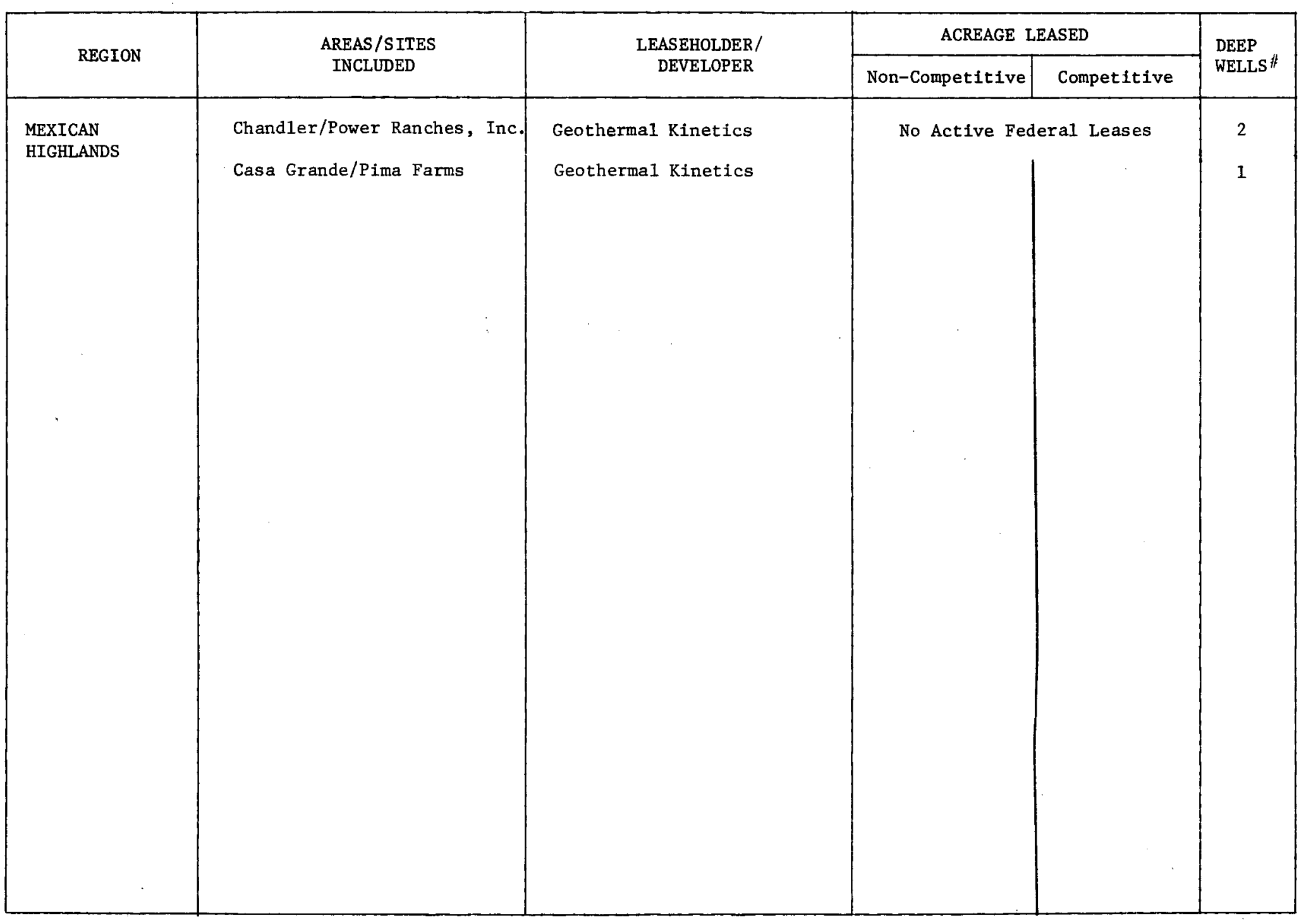

"Wells over 2000 feet known to be producible. 
STATE: _ ARIZONA

TABLE 3

ELFCTRIC POWER AND DIRECT USE DEVELOPMENT ACTIVITY
Code: UC"

PR - Proposed

$O P$ - Operating

U - Unknown

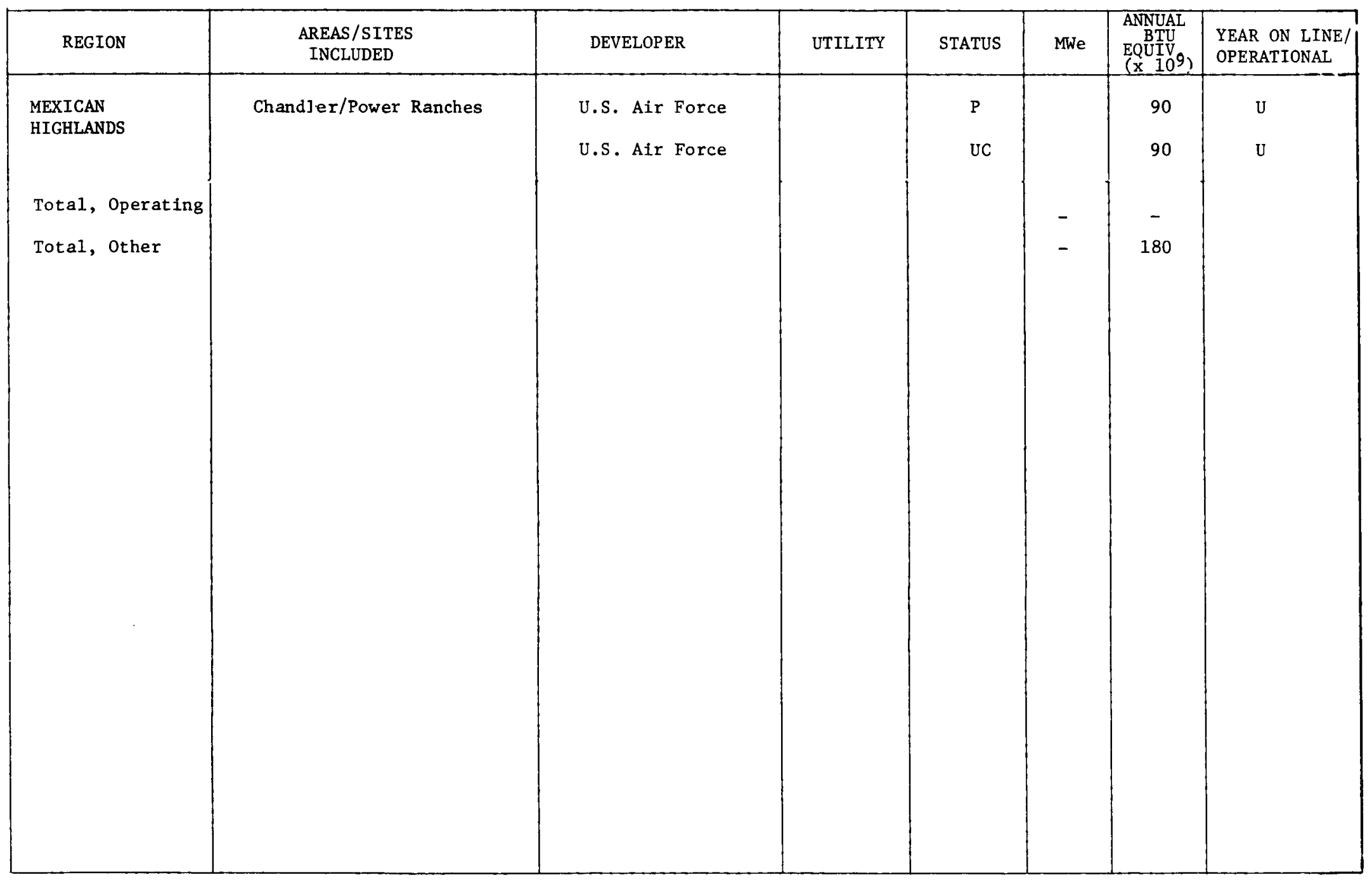

"For direct heat projects, construction begins with preliminary development activities such as exploratory drilling. 
Impacts and controls and controversies over which level of government (federal, state, or county) will control expanded access to the resource and benefit from production royalties and taxes. Regardless of how these institutional issues are resolved, installed capacity at The Geysers should at least double by 1990 , from the current $902 \mathrm{MW}$.

In the Salton Trough/Imperial Valley area, more than a decade of exploration, reservolr confirmations, and conversion technology research and engineering tests have brought this area to the brink of commercial development of electric power. The next three to flve years will be very important in determining whether the substantial efforts to date to reduce both technical problems and financial risks assoclated with these reservoirs have been sufficient to bring them into routine commercial development.

The princlpal geothermal development activities in California have occurred in eight areas, as shown in Figure 3.

Leasing and Exploration

Most of the land under federal lease in California is held compet1tively in the Salton Trough/Imperia1 Valley region and in the Geysers-Calistoga KGRA. Greatest competitive leaseholders are Republic Geothermal in the Imperial Valley and Shell 011 and Union/Magma/Thermal in The Geysers-Ca11stoga KGRA.

The majority of the completed deep geothermal wells are situated in the Geysers-Calistoga KGRA and at several sites within the Imperial Valley. The principal developers at The Geysers are Union 0il, Magma Power, and Thermal Power, who have completed more than 160 deep producible geothermal wells since the mid-1960's. Other developers active in the area include Aminotl U.S.A. and She11 011. Natomas Company now owns the leases developed by Magma Power and Thermal Power at The Geysers.

The Imperial Valley sites have not been proven for electric power production on commerclal scale. There have been a few deep well completions each year since extensive development began in the mid-1970's. Union 011 and Republic Geothermal have completed most of the deep geothermal wells. More detalled information pertaining to lands leased and/or explored is shown in Table 4.

\section{Direct Heat Applications}

Within the Lassen Known Geothermal Resource Areas, there are elght geothermal direct use developments. Hydropontc Farms and Hydroponics Inc. are operating a total of 36 geothermal greenhouses. Geothermal process energy is also being utilized by Hydroponic Farms to dry vegetables and wood waste. These applications currently consume about 47 billion Btu per year. The City of Susanville is constructing two separate district heating systems. The first project, which has received partial funding from the Department of Housing and Urban Development and the Farmers Home Administration, will retrofit 126 low- to moderate-income residences. Under the second project, 17 public bufldings will be heated with geothermal energy. Partial funding has been provided by the Economic Development Administration. These direct use projects currently consume 66 billion Btu per year.

The Mono County Water District (Mammoth Lakes area) has proposed a residential and commerclal district heating application. Annual geothermal utilization may reach 20 bilion Btu.

Within the Salton Trough/Imperial Valley area, 13 direct use projects are under active consideration. Those applications span the East Mesa, Heber, and Salton Sea KGRAs and E1 Centro, Niland, and Brawley.

VTN Consolidated is investigating the economic feasibility of an industrial process heat application near East Mesa. San Diego Gas and Electrfc uses geothermal energy in a process heating and hot water application in Heber. Within the Salton Sea KGRA, Nakashima Nursery is pursuing four geothermal greenhousing developments.

\section{Electric Power Development}

Nearly all commercial geothermal electricity in the U.S. Is generated from the geothermal resource in the Geysers-Calistoga KGRA. All fifteen units currently on line in The Geysers field have been developed by the Pacific Gas \& Electric Company (PG\&E). Collectively, these units generate a total capacity of 902 MWe of electricity. PG\&E's nine proposed additional units, now in the construction, design and planning stages of development, will add 935 MWe of additional capacity by 1990. Elght additional geothermal electric power plants are being proposed by other utilities in The Geysers area. These faclitities, also in varled stages of development, are expected to generate a total capacity of 551 MWe of electricity by 1985 . 


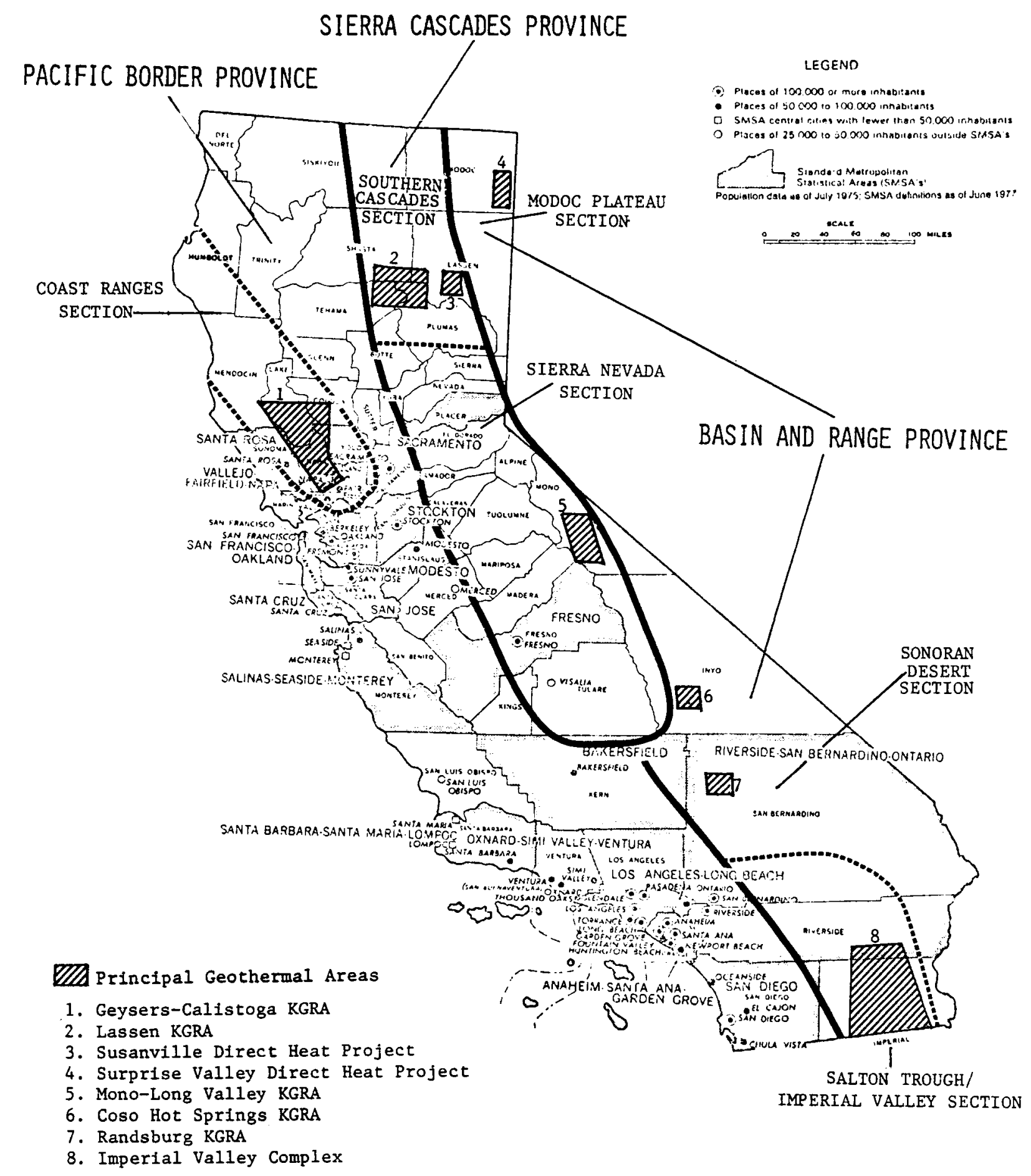

Figure 3

Principal Geothermal Resource Areas in California 
STATE: CALIFORNIA

TABLE 4

LANDS LEASED AND/OR EXPLORED

\begin{tabular}{|c|c|c|c|c|c|}
\hline \multirow{2}{*}{ REGION } & \multirow{2}{*}{$\begin{array}{l}\text { AREAS/SITES } \\
\text { INCLUDED }\end{array}$} & \multirow{2}{*}{$\begin{array}{l}\text { LEASEHOLDER* / } \\
\text { DEVELOPER }\end{array}$} & \multicolumn{2}{|c|}{ ACREAGE LEASED } & \multirow{2}{*}{$\begin{array}{l}\text { DEEP } \\
\text { WELLS }\end{array}$} \\
\hline & & & NON-COMPETITIVE & COMPETITIVE & \\
\hline SOUTHERN CASCADES & $\begin{array}{l}\text { Lassen KGRA } \\
\text { Morgan Springs - Growler } \\
\text { Lassen } \\
\text { Susanville }\end{array}$ & Phillips Petroleum & No Active & Federal Leases & 1 \\
\hline SIERRA NEVADA & $\begin{array}{l}\text { Mono Long Valley KGRA } \\
\text { Mammoth Lakes }\end{array}$ & $\begin{array}{l}\text { Geothermal Resources } \\
\text { International } \\
\text { City of Burbank }\end{array}$ & & $\begin{array}{l}3710 \\
1773\end{array}$ & \\
\hline SONORAN DESERT & $\begin{array}{l}\text { Coso H.S. KGRA } \\
\text { Randsburg KGRA }\end{array}$ & $\begin{array}{l}\text { Kerr - McGee } \\
\text { Chemical Corp. }\end{array}$ & & & \\
\hline $\begin{array}{l}\text { SALTON TROUGH/ } \\
\text { IMPERIAL VALLEY }\end{array}$ & $\begin{array}{l}\text { East Mesa KGRA } \\
\text { Heber KGRA } \\
\text { Westmorland KGRA } \\
\text { Salton Sea KGRA } \\
\text { Brawley KGRA } \\
\text { E1 Centro } \\
\text { Niland }\end{array}$ & $\begin{array}{l}\text { Bureau of Reclamation } \\
\text { Chevron USA } \\
\text { Holly Sugar Corp. } \\
\text { Magma Energy } \\
\text { Magma Power } \\
\text { Mapco } \\
\text { Natomas Company } \\
\text { Phillips Petroleum } \\
\text { Republic Geothermal } \\
\text { Union Oil } \\
\text { VTN et al. } \\
\text { Private Individuals } \\
\text { Other }\end{array}$ & $\begin{array}{r}2243 \\
641 \\
2120 \\
641\end{array}$ & $\begin{array}{r}10 \\
5065\end{array}$ & $\begin{array}{l}4 \\
4 \\
- \\
3 \\
5\end{array}$ \\
\hline COAST RANGES & Geys ers-Calistoga KGRA & $\begin{array}{l}\text { Aminoil/Occidental } \\
\text { Aminoil USA } \\
\text { Occidental Geothermal } \\
\text { Pacific Energy } \\
\text { Shell Oil } \\
\text { State of California } \\
\text { Thermogenics } \\
\text { Union-Magma-Thermal } \\
\text { Other }\end{array}$ & & $\begin{array}{r}394 \\
745 \\
549 \\
\\
6934 \\
471 \\
175 \\
5889\end{array}$ & $\begin{array}{r}- \\
38 \\
2 \\
10 \\
15 \\
10 \\
166 \\
12\end{array}$ \\
\hline
\end{tabular}


Two electric power generating plants have been on line in the Imperial Valley. A 10 MWe plant in the Brawley KGRA, the first flashed steam plant to operate in the U.S., came on 1 ine in 1980 . A 10 MWe pilot-scale binary-cycle plant also began operation in 1980. Accidental mechanical damage to the turbine forced the plant to shut down in November of the same year. The plant is currently on-line, but has not reached full operational status.

Nine additional plants are proposed for the Imperial Valley; these units have a potential generating capacity 403 MWe of power by 1986 .

Other proposed power plants in California are located in the Coso, Mono-Long Valley, and Wendel-Amedee KGRAs. Both the Mono-Long Valley and Wendel-Amedee facilities are hybrid units, which utilize a combination of wood waste and geothermal fluid as energy sources. When operational, they will generate a total of 125 MWe of electricity.

Details of the projects summarized above are given in Tables 5 and 6 .

Recent Major Activities

- Coso Land Order Modification Agreement Reached

The Secretary of the Navy and the Department of the Interior have agreed to permit development of the high potential geothermal resource at the China Lake Naval Weapons Center in the Coso Hot Springs area. The BLM is scheduled to offer lands in the Coso KGRA in a competitive lease sale in September. The original regional land order giving the Navy jurisdication over about 30,000 acres in the coso area did not allow for leasing of the geothermal resource. The Navy and BLM began to negotiate in December 1977 to allow leasing of the public-domain land at the China Lake facility. According to Dr. Carl Austin, head of the Geothermal Utilization Division at China Lake, the agreement could set a precedent for similar agreements regarding development of Department of Defense-controlled lands.

Source: PIC NGS, $6 / 5 / 81$

\section{- California to Propose Transfer of Federal Land to State}

The California State Lands Commission is developing a proposal to transfer 2,000 acres of federal land in The Geysers KGRA to state ownership. California is also seeking mineral rights, now held by the federal government, to an additional 3,000 acres which it already owns in the kGRA.

The land transfer results from state indemnity selection provisions of federal law, under which California is due to receive 115,000 acres of federal land, the equivalent of two sections of federal land in each township at the time of statehood. The law provides that where the federal lands were already being used, the states could select other land. Restrictions on the State's selection are "a grey area" according to the BLM, Ukiah District office, and it "appears" the state could even select land already in geothermal production.

The change in ownership would have many effects. The lands would no longer be controlled by the $B L M$ and the fight for legislation ( $A B$ 1905) to divert some of the federal geothermal revenues to the county of origin would have to be fought again at a state level.

Source: The Geyser, 4/30/81.

\section{- Geothermal Resource Ownership Litigation}

The Ninth Circuit Court of Appeals recently reversed a federal district court decision asserting Union $0 i 1$ of California's rights to geothermal resources beneath property at The Geysers and denying the federal government's rights to such resources. The Circuit Court concluded that, because geothermal resources were depletable subsurface reservoirs of energy akin to coal and oil deposits and because all elements of a geothermal system could be classified as minerals, the resource should be treated as a "mineral" within the meaning of the federal government's patent reservations.

In a second case involving Geothermal Kinetics, Inc. and Union Oil of California, the lessee of the mineral rights owner and the lessee of the surface owner each claimed ownership of the geothermal resources beneath a land parcel at The Geysers. The California Court of Appeals ruled that The Geysers geothermal resource was a "self-contained deposit...similar to minerals such as ofl, natural gas, and coal," thus indicating that mineral ownership would include geothermal resources.

A third case involved a dispute between the State of California and a surface owner, each of whom claimed the right to royalties from steam used to generate electric power at The Geysers. The court determined that the geothermal resource system, being a depletable deposit having numerous mineral components, was a "mineral deposit", thereby ruling that the state is the owner of the geothermal resource beneath the lands in question.

Source: Geothermal Energy Magazine, 3/81. 
TABLE 5

ELECTRIC POWER AND DIRECT USE DEVELOPMENT ACTIVITY
Code: $\mathrm{UC}^{\sharp}$ - Under Construction

PR - Proposed

CP - Operating

U - Unknown

A - Abandoned

\begin{tabular}{|c|c|c|c|c|c|c|c|}
\hline REGION & $\begin{array}{l}\text { AREAS/S ITES } \\
\text { INCLUDED }\end{array}$ & DEVELOPER & UTILITY & STATUS & MHe & $\begin{array}{l}\text { ANNUAL } \\
\text { BTU } \\
\text { EQUIV. } \\
\left(\times 10^{9}\right)\end{array}$ & $\begin{array}{l}\text { YEAR ON LINE/ } \\
\text { OPERATIONAL }\end{array}$ \\
\hline 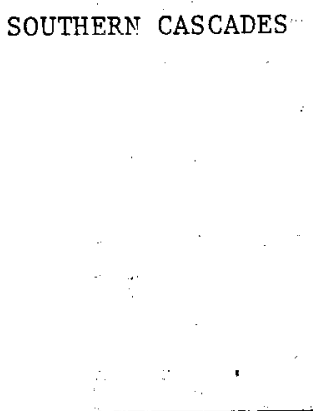 & $\begin{array}{l}\text { Susanville } \\
\text { Lassen KGRA }\end{array}$ & $\begin{array}{l}\text { Susanville/Oakey } \\
\text { Nursery } \\
\text { California Correctional Center } \\
\text { City of Susanville } \\
\text { City of Susanville } \\
\text { Hydroponic Farms } \\
\text { Hydroponics Inc. } \\
\text { Lassen College }\end{array}$ & $\begin{array}{l}- \\
- \\
- \\
- \\
- \\
- \\
-\end{array}$ & $\begin{array}{l}\text { PR } \\
\text { PR } \\
\text { UC } \\
\text { UC } \\
\text { OP } \\
\text { OP } \\
\text { PR }\end{array}$ & $\begin{array}{l}- \\
- \\
- \\
- \\
- \\
- \\
-\end{array}$ & $\begin{array}{l}.5 * \\
60 * \\
41 \\
25 * \\
29 \\
18 \\
100 *\end{array}$ & $\begin{array}{l}\mathrm{U} \\
1982 \\
1981 \\
\mathrm{U} \\
1978 \\
1972 \\
\mathrm{U}\end{array}$ \\
\hline SIERRA NEVADA & $\begin{array}{l}\text { Mono-Long Valley } \\
\text { KGRA } \\
\text { Mammoth Lakes }\end{array}$ & $\begin{array}{l}\text { Southern California Edison } \\
\text { County Water District }\end{array}$ & $\begin{array}{l}\text { Southern Cali- } \\
\text { fornia Edison } \\
-\end{array}$ & $\begin{array}{l}\mathrm{PR} \\
\mathrm{PR}\end{array}$ & $\begin{array}{r}20 \\
-\end{array}$ & $20 *$ & $\begin{array}{l}\mathrm{U} \\
\mathrm{U}\end{array}$ \\
\hline $\begin{array}{c}\text { SONORAN DESERT } \\
\vdots \\
\vdots\end{array}$ & $\begin{array}{l}\text { Coso H.S. KGRA } \\
\text { San Bernardino }\end{array}$ & $\begin{array}{l}\text { California Energy } \\
\text { California Energy } \\
\text { City of San Bernardino }\end{array}$ & $\begin{array}{l}\text { U.S. Navy } \\
\text { U.S. Navy }\end{array}$ & $\begin{array}{l}\mathrm{PR} \\
\mathrm{PR} \\
\mathrm{PR}\end{array}$ & $\begin{array}{r}20 \\
55 \\
-\end{array}$ & $\begin{array}{r}- \\
- \\
100\end{array}$ & $\begin{array}{c}1984 \\
1989 \\
U\end{array}$ \\
\hline 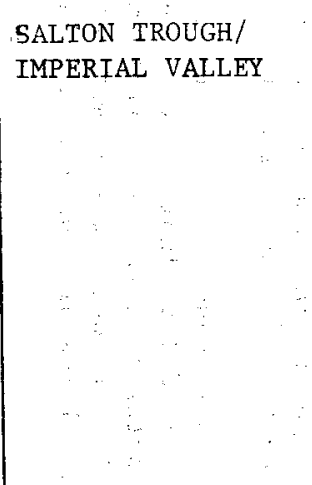 & $\begin{array}{c}\text { East Mesa KGRA } \\
\text { Heber KGRA } \\
\vdots\end{array}$ & $\begin{array}{l}\text { Magma Power } \\
\text { Repub1ic Geothermal } \\
\text { VTN Consolidated } \\
\text { Chevron } \\
\text { Chevron : } \\
\text { Chevron }\end{array}$ & $\begin{array}{l}\text { San Diego } \\
\text { Gas \& Electric } \\
\text { San Diego } \\
\text { Gas \& Electric } \\
\quad- \\
\text { San Diego } \\
\text { Gas \& Electric } \\
\text { Southern Cali- } \\
\text { fornia Edison } \\
\text { Southern Cali- } \\
\text { fornia Edison }\end{array}$ & $\begin{array}{l}10 \\
P R \\
P R \\
P R \\
P R \\
P R\end{array}$ & $\begin{array}{l}- \\
50^{* *} \\
- \\
45 \\
50 \\
100\end{array}$ & $\begin{array}{c}- \\
- \\
100 * \\
- \\
- \\
-\end{array}$ & $\begin{array}{c}1980 \\
- \\
U \\
1984 \\
1984 \\
1989 \\
.\end{array}$ \\
\hline
\end{tabular}


STATE:

CALIFORNIA

TABLE 5 (Continued)

ELECTRIC POWER AND DIRECT USE DEVELOPMENT ACTIVITY

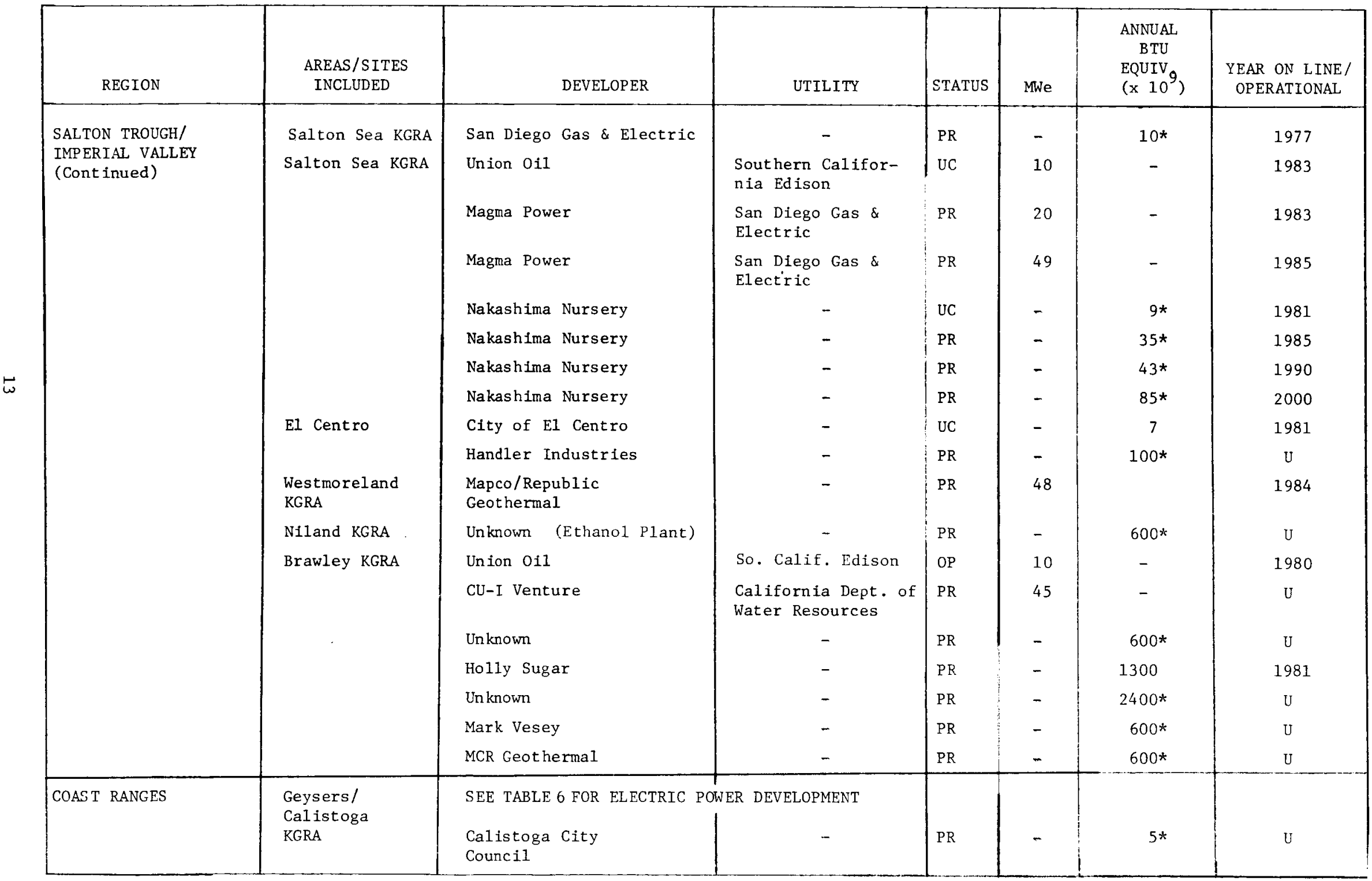

Code: $U C^{\#}$ - Under Construction

PR - Proposed

OP - Operating

U - Unknown 
STATE:

CALIFORNIA

TABLE 5 (Concluded)

ELECTRIC POWER AND DIRECT USE DEVELOPMENT ACTIVITY
Code: $U^{\#}$ - Under Const ruction

PR - Proposed

OP - Operating

U - Unknown

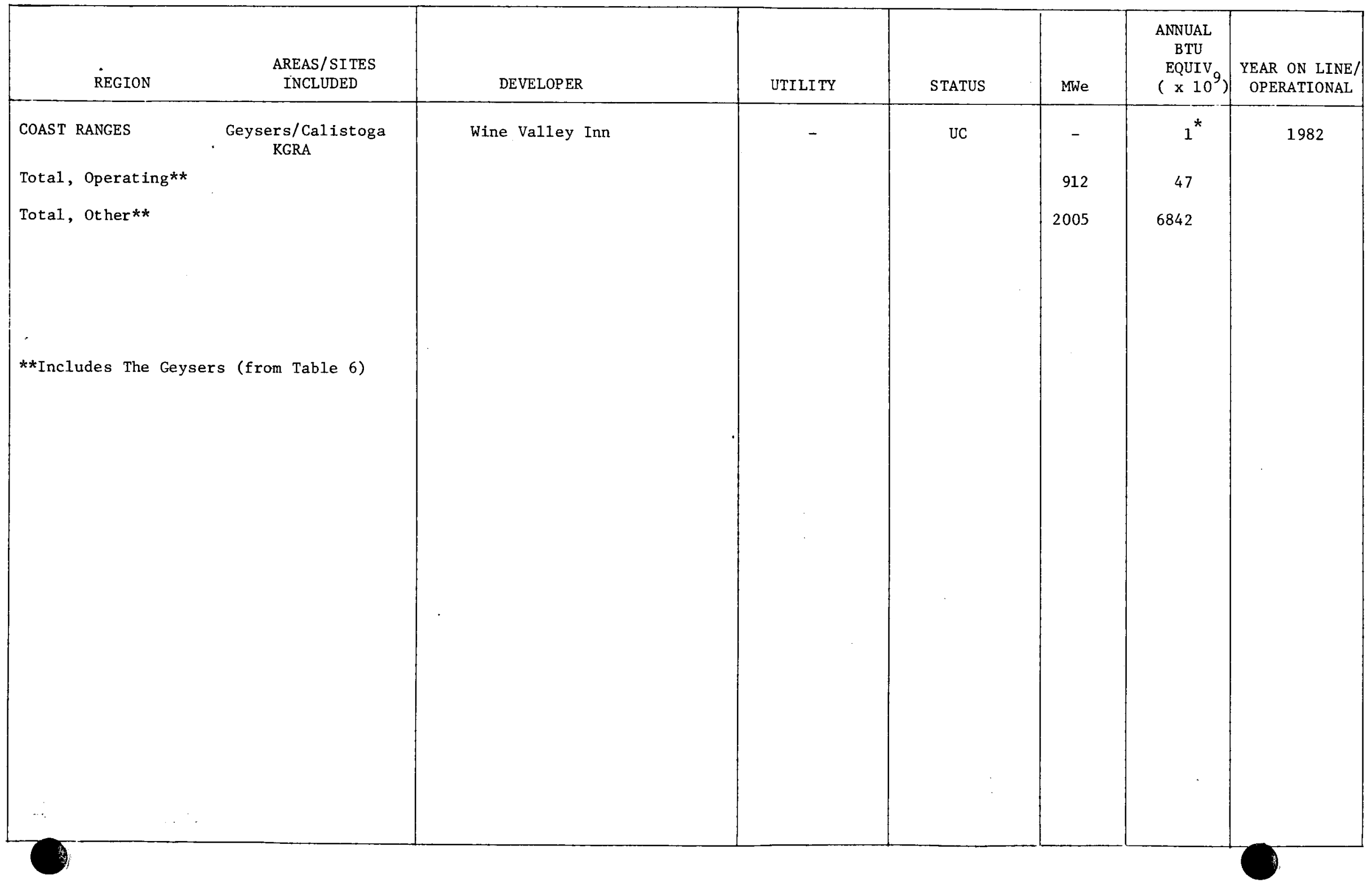


TABLE 6

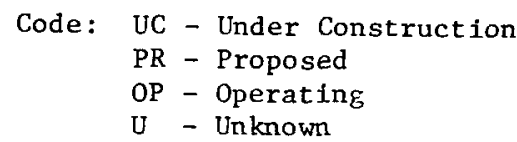

ELECTRIC POWER DEVELGPMENT AT GEYSERS/CALISTOGA KGRA

\begin{tabular}{|c|c|c|c|c|}
\hline DEVELOPER & UTILITY & STATUS & $\begin{array}{l}\text { MWe } \\
\text { NET }\end{array}$ & YEAR ON LINE \\
\hline Union-Magma-Thermal & $\begin{array}{l}\text { Pacific Gas \& Electric } \\
\text { Co. (PG\&E) }\end{array}$ & $\mathrm{OP}$ & 11 & 1960 \\
\hline Union-Magma-Thermal & PG\&E & OP & 13 & 1963 \\
\hline Un ion-Magma-Therma1 & PG\&E & OP & 27 & 1967 \\
\hline Un ion-Magma-Thermal & PG\&E & OP & 27 & 1968 \\
\hline Union-Magma-Thermal & PG\&E & OP & 53 & 1971 \\
\hline Union-Magma-Thermal & PG\&E & OP & 53 & 1971 \\
\hline Union-Magma-Thermal & PG\&E & OP & 53 & 1972 \\
\hline Union-Magma- Thermal & $P G \& E$ & OP & 53 & 1972 \\
\hline Un Ion-Magma-Thermal & PG\&E & OP & 53 & 1973 \\
\hline Union-Magma-Thermal & PG\&E & OP & 53 & 1973 \\
\hline Un ion-Magma-Thermal & PG\&E & OP & 106 & 1975 \\
\hline Union-Magma-Thermal & $P G \& E$ & OP & 106 & 1979 \\
\hline Union-Magma-Thermal & Aminoil USA & OP & 129 & 1980 \\
\hline Un ion-Magma-Thermal & Union-Magma-Therma1 & OP & 110 & 1980 \\
\hline Union-Magma-Thermal & Thermogenics & $O P$ & 55 & 1979 \\
\hline Aminoil USA & PG\&E & PR & 110 & 1983 \\
\hline Unton-Magma-Thermal & PG\&E & UC & 110 & 1982 \\
\hline Union-Magma-Therma1 & PG\&E & $\mathrm{UC}$ & 110 & 1982 \\
\hline Aminoil USA & $P G \& E$ & PR & 55 & 1986 \\
\hline Union-Magma-Thermal & $P G \& E$ & PR & 110 & 1986 \\
\hline Union-Magma-Thermal & PG\&E & PR & 110 & 1986 \\
\hline Union-Magma-Therma1 & PG\&E & PR & 110 & 1990 \\
\hline Union-Magma-Thermal & PG\&E & PR & 110 & 1990 \\
\hline Union-Magma-Therma1 & PG\&E & PR & 110 & 1990 \\
\hline Geothermal Kinetics & CA Dept. of Water Resources & PR & 55 & 1986 \\
\hline $\mathrm{MCO}$ & CA Dept. of Water Resources & $\mathrm{UC}$ & 55 & $1983 / 1984$ \\
\hline $\mathrm{MCO}$ & CA Dept. of Water Resources & PR & 55 & 1986 \\
\hline $\mathrm{MCO}$ & $\begin{array}{l}\text { Northern California Power } \\
\text { Agency }\end{array}$ & $\mathrm{PR}$ & 66 & 1985 \\
\hline Shel1 oil Co. & $\begin{array}{l}\text { Northern California Power } \\
\text { Agency }\end{array}$ & UC & 110 & 1982 \\
\hline Aminoil USA & $\begin{array}{l}\text { Sacramento Municipal } \\
\text { Utility District }\end{array}$ & $\mathrm{UC}$ & 72 & 1983 \\
\hline Shell oil & Central Calif. Power Agency & PR & $55-75$ & $\mathrm{U}$ \\
\hline $\begin{array}{l}\text { Occidental Geothermal, } \\
\text { Inc. }\end{array}$ & - & PR & 80 & 1984 \\
\hline
\end{tabular}




\section{- Callfornia Energy Fund}

A bill passed by the Calffornia Senate early this year established the State Assistance Fund for Energy Business and Industrial Development Corporation (SAFE-BIDCO). The non-profit corporation provides financial assistance in the form of direct loans to small businesses in the alternative energy Industry or to small businesses planning to convert to alternative energy systems, including geothermal energy systems. The loan program has begun with a $\$ 2.5$ militon 1 ine of credit from the state. A11 loans are to be partially guaranteed by the U.S. Small Business Administration. The guaranteed portion of the loans may then be sold to private investors in the capttal market, allowing SAFE-BIDCO to regain its investment for continued lending.

Source: SAN Monthly Report, 5/8/81.

\section{- Lake County Alliance Asks for Additional State Geothermal Revenues}

A compaign to gain additional monies for local governments from state geothermal revenues has been inftiated in Lake County, California. The Lake County Alliance, a nonprofit informational and educational organization working for economic and social improvement in Lake County, has launched efforts to obtain additional geothermal revenues for local government.

Counties of origin now recelve a portion of federal geothermal lease and royalty monfes under terms of Assembly Bill 1905, introduced by Assemblyman Douglas Bosco. The Alliance is proposing simflar leglslation which would return state geothermal revenues to Lake and other counties with geothermal development.

The Alliance has asked the Lake County Board of Supervisors to support 1ts campaign and plans also to approach the Sonoma County Alllance and Sonoma County Board of Supervisors.

Source: GRC Bulletin, 5/81.

\section{- California State Legislature Funds Geothermal Projects}

The California State Legislature has allocated funds for at least two geothermal projects in this year's budget. About $\$ 2$ milition will be set aside for integration of geothermal and/or cogeneration systems into existing state facilities. A geothermal heating system being installed in a Susanville correctional center is expected to receive the bulk of the funds. Additionally, the budget authorizes about $\$ 400,000$ for a sewage treatment plant in San Bernardino which will utilize geothermal process heat.

\section{Source: SAN Weekly Activity Report, 6/18/81.}

\section{- Calistoga, California Debates Geothermal Energy Use}

At a Cal1stoga City Council meeting held In March 1981, the use of geothermal water to space condition the proposed Wine Valley Inn was promoted by some as a way to save energy and help curb rising utflity rates. However, several spa owners and bottled water company managers commented that the planned reinjection process could cool the geothermal pool and that an accident could pollute the pool, rendering it useless to other commercial entities. Opponents of the project sought modification or revocation of a use permit issued for construction of the planned facility.

Engineers from the State Department of Mines and Geology, the Division of 011 and Gas, and the Department of Health Services spoke to the Counc11, giving the preliminary results of a year-1ong examination of Calistoga's geothermal pool and reporting on requirements imposed by the state on people who tap the pool. The Council was told that the Division of 011 and Gas reviews all profects to determine what treatment is given the water, how and how fast it is reinjected, and the characteristics of the ground in the reinjection area. It was also noted that the state has the power to close down the well if there is evidence of damage and that it would stop the sale of bottled water if the geothermal pool became polluted.

The Crystal Geyser Water Company suggested that McNu1ty post a $\$ 30$ million bond to cover destruction of the geothermal pool.

\section{Source: SAN Monthly Report, 5/8/81.}

\section{- Test We1ls for Callfornia Correctional Center Drilled}

The Lassen County Planning Commission has granted a use permit to the Carson Development Company to drill wells for a prison retrofit. A 300-acre geothermal lease has been obtained at the site and an additional 400-acre surface development lease is under negotiation. The hot water will be piped 
to the prison for geothermal space heating and returned for uses such as greenhousing, ethanol production, and swine raising.

Correctional center officials have requested $\$ 1.7$ million for the geothermal retrofit and conservation measure, al.though authorization has not yet been announced. The City of Susanville will manage the project and sell geothermal water to the center. Officials are hoping to displace 600,000 gallons of heating oil annually, or 70 percent of the prison's current use of oil. The city is also applying for $\$ 90,000$ in funds for engineering design.

Source: Lassen Advocate, Susanville, CA, 3/9/81.

\section{- BLM Proposals Announced}

Recent BLM actions on several California sites are listed below:

East Mesa - The final EA has been published. Forty-five pending noncompetitive lease applications can now be processed. (The area does not include the East Mesa KGRA).

Glamis/Dunes - A draft EA has been published. The action should allow processing of 38 noncompetitive leases and will make available a total lease area of 194,000 acres, including the Glamis and Dunes KGRAs, to be scheduled for lease sale pending the outcome of the public comments on the areas.

Yuha Desert - The final Environmental Analysis has been published, clearing the way for noncompetitive leasing in nine geothermal areas.

Pisgah - An EAR for geothermal and sodium leasing has been prepared.

Source: GRC Bulletin, Feb. - March/81.

\section{- Power Plant Development Activities Continue}

Recent development activities at specific geothermal power plant sites in California are summarized below.

\section{Heber - Southern California Edison Co.}

The California Public Utilities Commission has rejected Southern California Edison's application for a Certificate of Public Convenience and Necessity for the 50 MWe flash steatn geothermal power plant at Heber. Southern California Edison (SCE) has a fuel contract agreement with Chevron for the plant.

Source: Southern California Edison, $7 / 81$.

\section{Geysers - Pacific Gas \& Electric Company Unit \#16}

Pacific Gas \& Electric Company (PG\&E) has been granted a Certificate of Public Convenience and Necessity by the California Public Utilities Commission (CPUC) to construct and operate a double-circuit $230 \mathrm{kV}$ transmission line between Lakeville Substation in Sonoma County and its Sobrante Substation in Contra Costa County. Construction is conditional on CPUC approval of Unit $\$ 16$ and a transmission line to the Lakeville Substation.

Source: GRC Bulletin, 5/81.

\section{Bottle Rock - California Department of Water Resources}

Ground breaking ceremonies were held May 6, 1981 for the Bottle Rock 55 MWe power plant located on the Francisco leasehold in The Geysers geothermal field. This facility will be constructed, owned and operated by the State of California's Department of Water Resources.

Ghillotti Brothers, Inc. of San Rafael, California submitted the lowest bid of $\$ 869,959$ for initial site development work.

Source: The Geyser, 5/81.

\section{Geysers - Sacramento Municipal Utility District}

Plant construction began on April 1, 1981 on SMUDGE0 \#1, a 75 MWe geothermal power plant, located in Eastern Sonoma County near the Lake County line. 
The California Energy Commission (CEC) has approved the California Department of Water Resources (DWR) Application for Certification (AFC) for its 55 MWe geothermal electric plant, located in the northeastern portion of Sonoma County.

Source: GRC Bulletin, 6/81.

\section{CCPA \#1 - Central California Power Agency}

The Sacramento Municipal Utility District (SMUD), acting as lead agency, has approved the formation of a joint power agency with the Modesto Irrigation District (MID) and the cities of Redding and Santa Clara. The consortium will be called the Central Californta Power Agency (CCPA) and is proposing the development of a 55-75 MWe geothermal electric power plant in northern California's Sonoma County.

MID and Shell 011 have signed an agreement for test drilling for the project. Engineers are currently studying possible test drilling sites on a 3200-acre lease block Shell acquired from Hilary Farms. Drilling is anticipated to begin in October on a 10,000 foot geothermal test well. MID has agreed to spend the first $\$ 2.2$ million on the test well and split further costs with Shell on a $50-50$ percentage basis.

Source: Petroleum Information Corporation, 4/10/81

Wendel-Amedee - Geoproducts Hybrid Plant

The Geoproducts Corporation of Oakland and the U.S. Department of Energy have s1gned $\$ 1.5$ million contract in a cooperative agreement to drill a 5000 foot geothermal production well near Wendel, California. The energy resources will be used to dehydrate a combination of wood wastes to be used for a 55 Me electrical demonstration plant. The California Department of Water Resources has agreed to purchase electricity from the plant for operation of the State Water Project.

Source: Petroleum Information Corporation, 4/24/81.

COLORADO

Low- to moderate-temperature resources can be found at scattered sites in Colorado. These are being used for direct heat applications.

\section{Leasing and Exploration}

Five areas in Colorado appear to have significant geothermal resource potential. Figure 4 shows the locations of these areas. There are no active federal leases and no completed deep wells in the identified resource areas.

\section{Direct Heat Applications}

Geothermal direct heat applications in the Alamosa area include heating of the Alamosa Shopping Center, barley malting, and a multiple-use project, currently under construction by the City of Alamosa, which incorporates space heating of Adams State College. In the San Luis Valley, projects are underway for process heating at Alamosa Mushroom Farms and commercial space heating of a shopping mall; another commercial space heating project and an ethanol plant have been proposed. Geothermal resources are being used for residential space heating and fish farming in the Sand Dunes area, and a greenhouse application has been proposed. These projects are listed in Table 7 .

Recent Major Activities

- Alamosa, Colorado Selected as Agripark Site

The Alamosa Mushroom Farm near Alamosa, Colorado has been chosen as the site for exploratory drilling in the second phase of a program to develop a geothermal-based industrial park in southern Colorado. The project is being funded by the Four Corners Regional Commission through the Southern Colorado Economic Development District (SCEDD).

A test geothermal production well to prove the on-site resource availability is scheduled to be drilled during the summer of 1981 . If the hot-water resource is confirmed as expected, the geothermal industrial park could play an important role in strengthening the San Luis Valley region's economy. Other proposed industries for the agripark include a poultry farm and greenhousing and aquacul tural applications. 


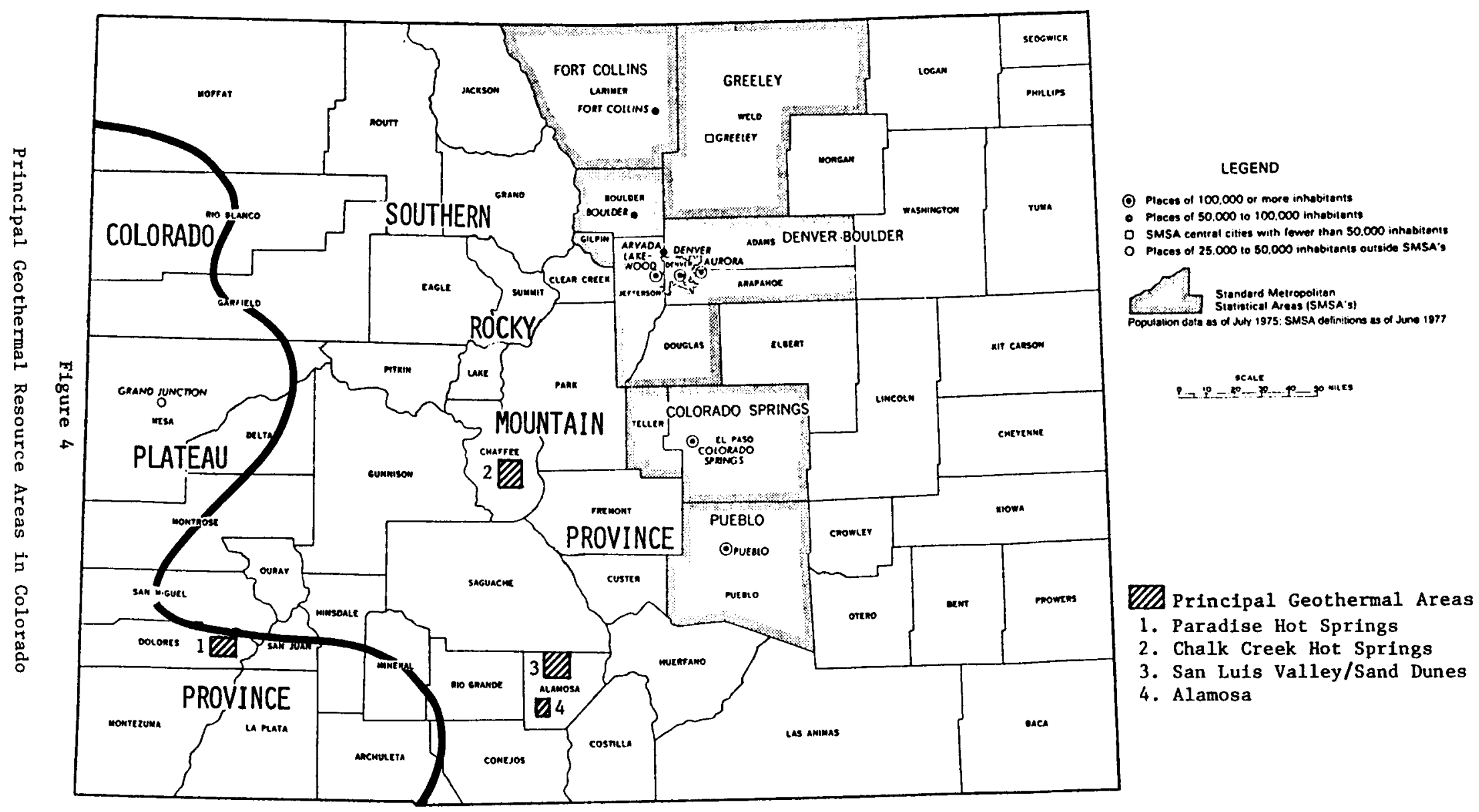


STATE : COLORADO

TABLE 7

ELECTRIC POWER AND DIRECT USE DEVELOPMENT ACTIVITY
Code: UC ${ }^{\#}$ - Under Construction

PR - Proposed

OP - Operating

U - Unknown

\begin{tabular}{|c|c|c|c|c|c|c|c|}
\hline REGION & $\begin{array}{l}\text { AREAS / STTES } \\
\text { INCLUDED }\end{array}$ & DEVELOPER & UTILITY & STATUS & MWe & $\begin{array}{l}\text { ANNUAL } \\
\text { BTU } \\
\text { EQUIV } \\
\left(x \quad 10^{9}\right)\end{array}$ & $\begin{array}{l}\text { YEAR ON-LINE/ } \\
\text { OPERATIONAL }\end{array}$ \\
\hline \multirow{10}{*}{$\begin{array}{l}\text { RIO GRANDE RIFT/SAN } \\
\text { LUIS DEPRESSION }\end{array}$} & \multirow[t]{3}{*}{ Alamnsa } & Alamosa Shopping Center & - & OP & - & $5 *$ & $U$ \\
\hline & & Baca Grande Corp. & - & $P R$ & - & $1 *$ & $U$ \\
\hline & & City of Alamosa & - & UC & - & $5 *$ & $\mathrm{U}$ \\
\hline & \multirow[t]{7}{*}{ San Luis Valley } & Alamosa Mushroom Farms & - & UC & - & $100 *$ & $\mathrm{U}$ \\
\hline & & Baca Grande Community & - & PR & - & $5 *$ & $\mathrm{U}$ \\
\hline & & Gibson Building & - & UC & - & $50 *$ & $\mathrm{U}$ \\
\hline & & Westec Services & - & PR & - & $1200 *$ & $\mathrm{U}$ \\
\hline & & B. R. Jenkins & - & OP & - & .7 & U \\
\hline & & B. R. Jenkins & - & $\mathrm{OP}$ & - & 50 & $\dot{U}$ \\
\hline & & Charles Underwood & - & PR & - & $.5 *$ & $\mathrm{U}$ \\
\hline \multirow{6}{*}{$\begin{array}{l}\text { Total, Operating } \\
\text { Total, Other }\end{array}$} & & & & & - & 55.7 & \\
\hline & & & & & - & 1361.5 & \\
\hline & & & & & & & \\
\hline & & & & & & & \\
\hline & & & & & & & \\
\hline & & & & & & & \\
\hline
\end{tabular}


- Geothermal Heating Proposed for Colorado State Buildings

Western Energy Planners, Ltd. recently completed a study showing economic feasibility of heating selected state buildings with geothermal energy. The study evaluated geothermal heating for state buildings in Alamosa, Buena Vista, Burlington, Durango, Glenwood Springs and Steamboat Springs and concluded that geothermal heating of 45 percent of the buildings studied was economical.

Source: GRC Bulletin, February/March 1981 .

HAWAII

Though only one geothermal project is operating in Hawaii, the state has one of the hottest geothernal resources in the world. This resource is currently being tapped to generate electricity in the Puna district and further development is planned. The first state leases for geothermal development on the Island of Hawai were recently signed.

\section{Leasing and Exploration}

The principal geothermal resource area in Hawaii is identified on the map in Figure 5. Two deep producible wells have been completed and several other sites have been staked preparatory to drilling. As shown in Table 8, no federal leases are currently held in Hawaii.

\section{Electric Power Development}

A 3 MWe geothernal power plant in the Puna district became operational in July 1981. The plant, located on the eastern rift zone of the Kilauea volcano, uses a wellhead generator. The project is the first to produce electricity from a geothermal resource in Hawaii and is expected to meet the electrical requirements of 3,500 people. The Hawaii Electric Light Company, which operates the plant, is also involved in the development of a proposed 25 MWe geothermal electric plant in the Puna district. Thermal Power Company and Dillingham Corporation recently formed a joint venture to pursue the development of this facility, which is scheduled to come on line in 1988.

These projects are shown in Table 9.

Recent Major Activities

\section{- State Leases Issued in Hawaii}

Hawaii's state land board has approved two leases for geothermal exploration on the Island of Hawaii. The leases, granted to Bishop Estate and Kapoho Land Partnership are the first geothermal leases to be signed in Hawaii. The two landowners will sublease the mineral rights to a joint venture of Dillingham Corporation of Hawaii and Thermal Power Company of California, who will drill wells for development of geothermal electric power eventually to be sold to the Hawaii Electric Light Company.

Source: SAN Monthly Report, 5/8/81

GRC Bulletin, 5/81

\section{IDAHO}

Idaho is a state of extensive direct heat development, most of which is in the Boise area. Electric power development is limited to a pilot-scale plant in the Snake River plain. The state has demonstrated its commitment to developing its geothermal resources by pursuing a project to retrofit the Capitol Mall for geothermal space heating.

$\underline{\text { Leasing and Exploration }}$

There are nine principal geothermal resource areas in Idaho, as shown in Figure 6.

Most leases in Idaho are held noncompetitively. The only competitive leaseholders in the identified geothermal resource areas are Magma Energy and Union Oil, who hold joint leases near Mountain Home, and Occidental Geothermal in the Crane Creek KGRA. Overall, the principal leaseholders are Magma/Union, Chevron USA, Sunedco, and Atlantic Richfield. The greatest amount of land is leased noncompetitively in the Snake River Plain region, which includes the Raft River area. 


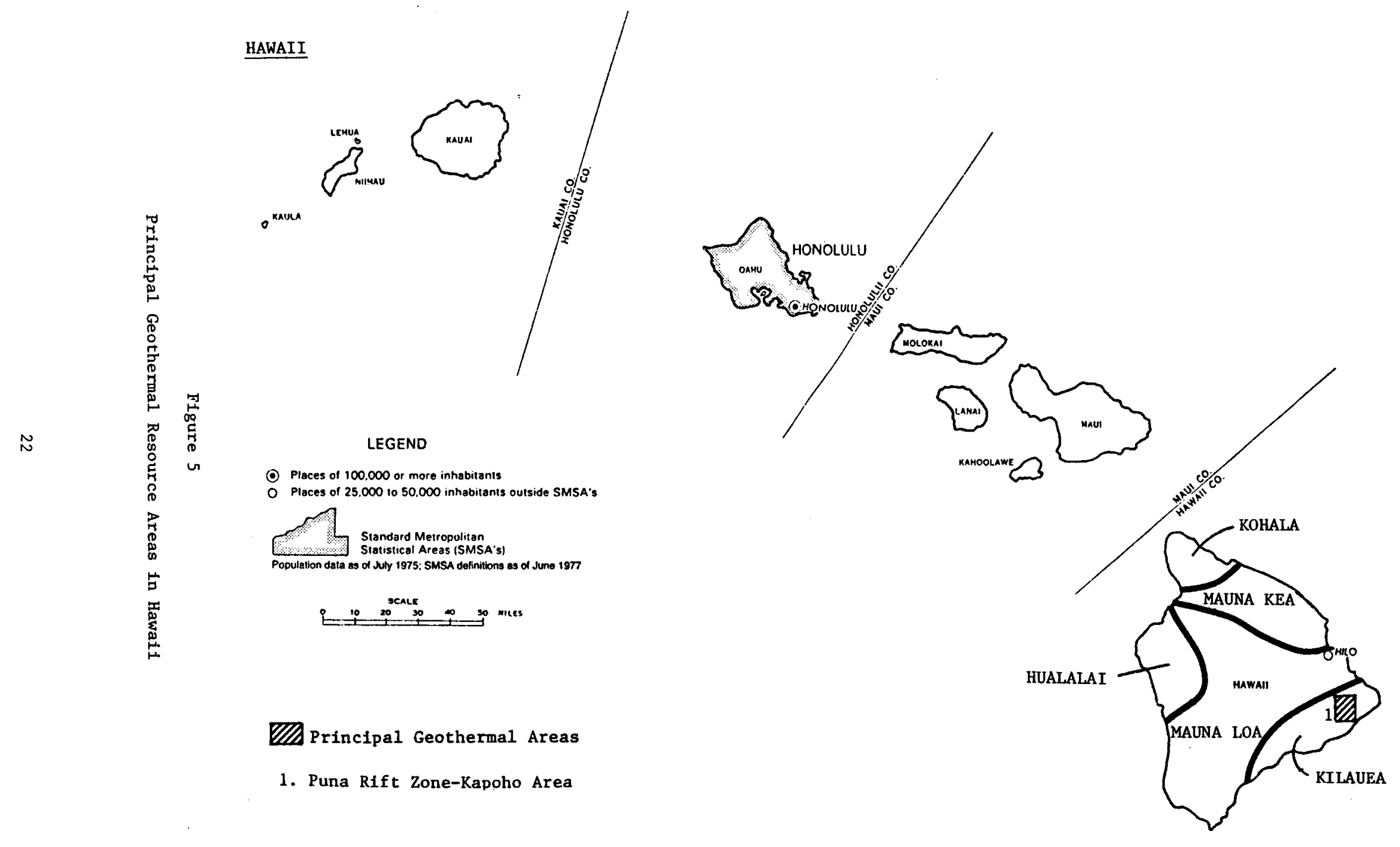


LANDS LEASED AND/OR EXPLORED

\begin{tabular}{|c|c|c|c|c|c|}
\hline \multirow{2}{*}{ REGION } & \multirow{2}{*}{$\begin{array}{l}\text { AREAS/SITES } \\
\text { INCLUDED }\end{array}$} & \multirow{2}{*}{$\begin{array}{c}\text { LEASEHOLDER / } \\
\text { DEVELOPER }\end{array}$} & \multicolumn{2}{|c|}{ ACREAGE LEASED } & \multirow{2}{*}{$\begin{array}{l}\text { DEEP } \\
\text { WELLS }\end{array}$} \\
\hline & & & Non-Competitive & Competitive & \\
\hline PUNA RIFT ZONE & Kapoho Area & $\begin{array}{l}\text { Hawaii Geothermal Project } \\
\text { Colorado School of Mines }\end{array}$ & No Active Fed & cal Leases & $\begin{array}{l}1 \\
1\end{array}$ \\
\hline
\end{tabular}


STATE: HAWAII

Code: UC - Under Construction

PR - Proposed

OP - Operating

TABLE 9

U - Unknown

ELECTRIC POWER AND DIRECT USE DEVELOPMENT ACTIVITY

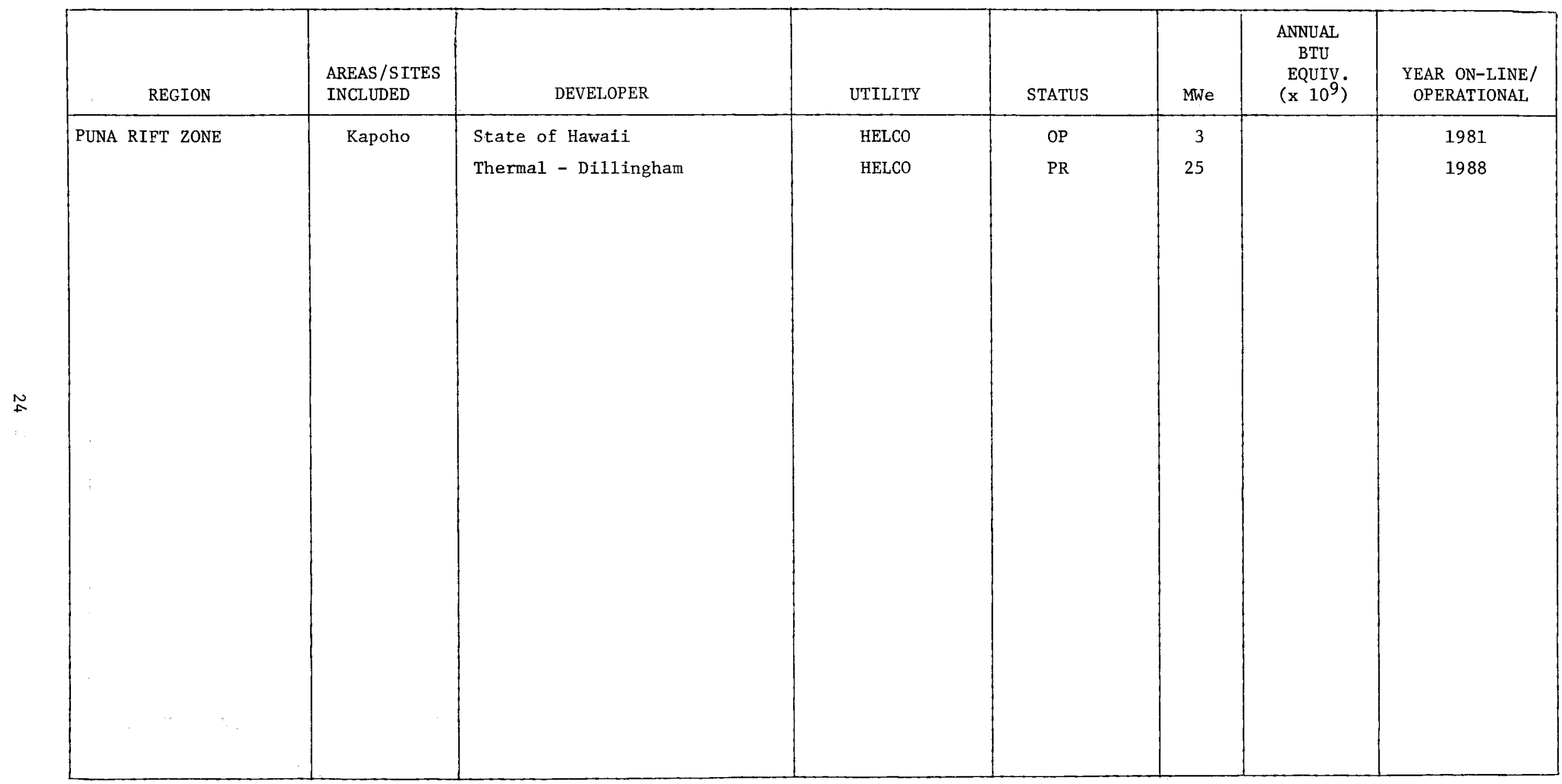

\# For direct heat projects, construction begins with preliminary development activities such as exploratory drilling.

${ }^{*}$ Annual energy use is a rough estimate. 
A total of five deep producible wells have been completed in Idaho. Details of the leasing and exploration activity are given in Table 10 .

Direct Heat Applications

Major uses of geothermal direct heat in Idaho are space heating, fish farming, food processing, and greenhousing.

Five geothermal direct heat projects are in operation in the Boise area. Most of these projects provide residential space heating. A system to provide space heating to seven state buildings, including the capitol, is under construction.

Near Mountain Home, the U.S. Air Force is investigating feasibility of a space heating project for the Air Force base.

Agricultural and industrial applications of geothermal resources of the Snake River Plain are proposed or under construction at Pocatello, Raft River, and Rexburg. These include a barley malting project at Pocatello, food processing at Rexburg, and in the Raft River area, fish farming, potato peel drying, and three ethanol plants.

Other Idaho projects which are currently in operation include greenhousing and tropical fish breeding at Buhl. Proposed applications include ethanol plants at Kimberly and Twin Falls and campus heating at the College of Southern Idaho in Twin Falls.

\section{Electric Power Development}

A 5 MWe pilot-scale geothermal electric power plant has been constructed in the Raft River KGRA. This plant was built under a DOE project to investigate and demonstrate the feasibility of generating electricity from moderate-temperature geothermal resources. The operating and testing phases for this unit will be carried out by EG\&G Idaho, Inc. and the Geothermal Power Development Group, a joint venture of four utilities ( Washington Public Power Supply System, Idaho Power Company, Raft River Rural Electric Cooperative, and the Snake River Power Association). Power on line is scheduled for the end of this year.

Details of electric power and direct heat projects in Idaho are presented in Table 11.

\section{MONTANA}

High-temperature resources are not known to exist in Montana. There are a few direct heat projects being carried out.

\section{Leasing and Exploration}

The locations of the two principal geothermal resource areas in Montana are shown in Figure 7 . As can be seen in Table 12, there are no active federal leases in the identified areas and only one deep, producible well has been completed.

\section{Direct Heat Applications}

Geothermal resources are being used at White Sulphur Springs for space heating of a bank and operation of a motel and spa. These projects are shown in Table 13.

\section{NEVADA}

Though there is now no geothermal electric power on line in Nevada, the state follows California in geothermal resource potential. The availability of promising high-temperature resources in Dixie Valley, Beowawe, and Steamboat Springs has prompted a group of regional utilities to form a consortium to develop geothermal power in the state.

\section{Leasing and Exploration}

As can be seen in Figure 8, Nevada contains numerous geothermal resource areas. However, deep producible wells have been completed at only five of the sites. 


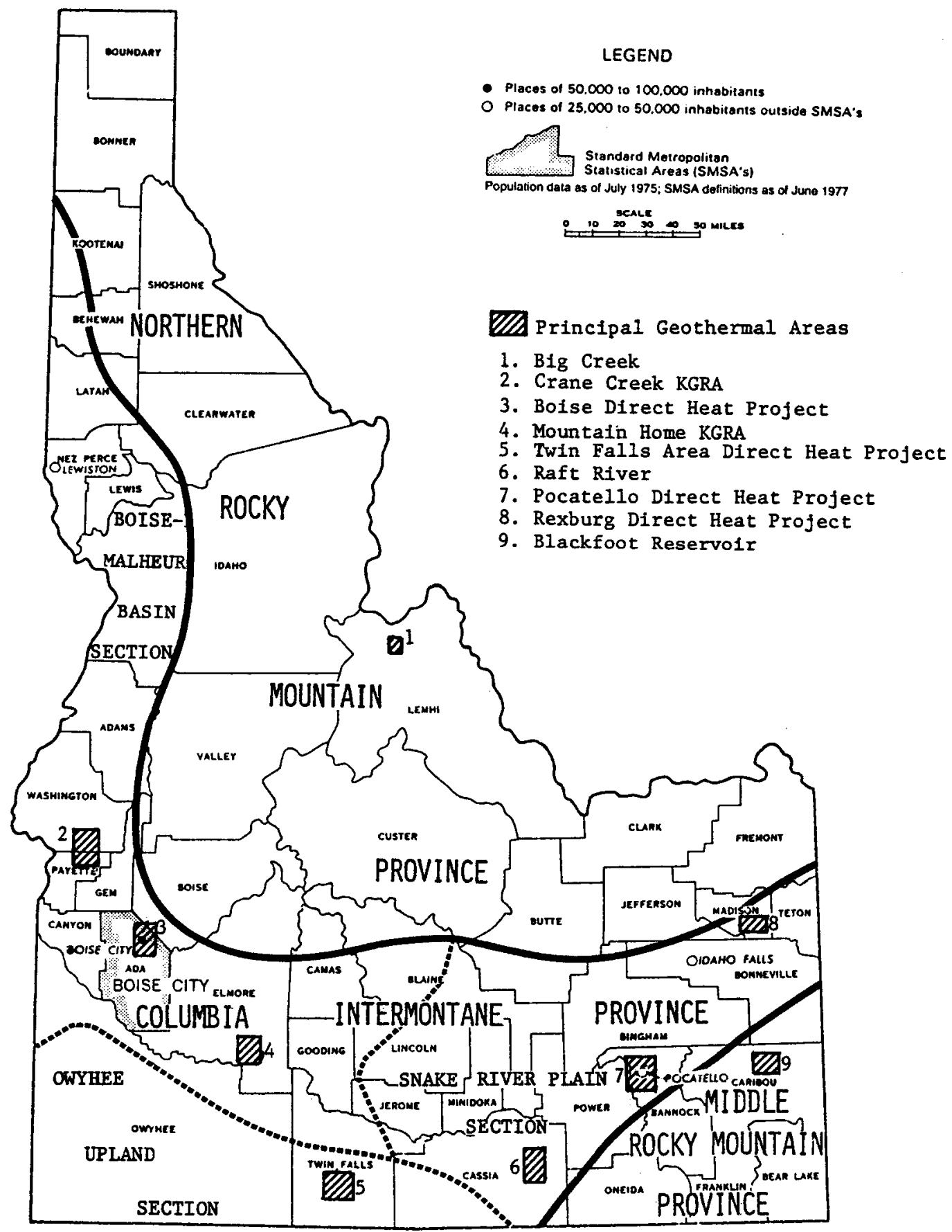

Figure 6

Principal Geothermal Resource Areas in Idaho 
STATE: IDAHO

TABLE 10

LANDS LEASED AND/OR EXPLORED

\begin{tabular}{|c|c|c|c|c|c|}
\hline \multirow{2}{*}{ REGION } & \multirow{2}{*}{$\begin{array}{l}\text { AREAS/SITES } \\
\text { INCLUDED }\end{array}$} & \multirow{2}{*}{$\begin{array}{l}\text { LEASEHOLDER* / } \\
\text { DEVELOPER }\end{array}$} & \multicolumn{2}{|c|}{ ACREAGE LEASED } & \multirow{2}{*}{$\begin{array}{l}\text { DEEP } \\
\text { WELLS }\end{array}$} \\
\hline & & & Non-Competitive & Competitive & \\
\hline $\begin{array}{l}\text { HIGH LAVA PLAINS / } \\
\text { MALHEUR-BOISE } \\
\text { BASIN }\end{array}$ & $\begin{array}{l}\text { Crane Creek KGRA/Cove } \\
\quad \text { Creek } \\
\text { Mountaln Home KGRA } \\
\text { Little Creek, H.S. } \\
\text { Boise }\end{array}$ & $\begin{array}{l}\text { Atlantic Richfield } \\
\text { Earth Power Corp. } \\
\text { Hassie Hunt Exploration } \\
\text { Magma/Union Oil Co. } \\
\text { Occidental Geothermal } \\
\text { State of Idaho } \\
\text { Therma1 Resources, Inc. } \\
\text { U.S. Geothermal Corp. } \\
\text { Private Individuals }\end{array}$ & $\begin{array}{r}5,609 \\
2,399 \\
4,574 \\
16,123 \\
\\
1,638 \\
3,120 \\
19,106\end{array}$ & $\begin{array}{l}5,983 \\
2,600\end{array}$ & 1 \\
\hline $\begin{array}{l}\text { SNAKE RIVER } \\
\text { PLAIN }\end{array}$ & $\begin{array}{l}\text { Pocatello } \\
\text { Rexburg } \\
\text { Raft River }\end{array}$ & $\begin{array}{l}\text { Anadarko } \\
\text { Chevron USA } \\
\text { INEL (DOE)/E.G.\& G. } \\
\text { Phillips Petroleum } \\
\text { Southland Royalty } \\
\text { Sunedco } \\
\text { Supron } \\
\text { Private Individuals }\end{array}$ & $\begin{array}{r}5,650 \\
14,908 \\
\\
2,020 \\
402 \\
13,704 \\
2,843 \\
21,968 \\
\end{array}$ & & 4 \\
\hline OWYHEE UPLAND & $\begin{array}{l}\text { Buhl } \\
\text { Kimberly } \\
\text { Miracle H.s. } \\
\text { Twin Falls }\end{array}$ & $\begin{array}{l}\text { Amax Exploration } \\
\text { Atlantic Richfield }\end{array}$ & $\begin{array}{r}7,501 \\
13,545\end{array}$ & & \\
\hline IDAHO BATHOLITH & Big Creek & & No Active Fer & eral Leases & \\
\hline
\end{tabular}

* Federal lands only.

非但s over 2000 feet known to be producible. 
STATE: IDAHO

TABLE 11

ELECTRIC POWER AND DIRECT USE DEVELOPMENT ACTIVITY
Code: $U C^{\#}$ - Under Construction

$P R$ - Proposed

OP - Operating

U - Unknown

\begin{tabular}{|c|c|c|c|c|c|c|c|}
\hline REGION & $\begin{array}{l}\text { AREAS/SITES } \\
\text { INCLUDED }\end{array}$ & DEVELOPER & UTILITY & STATUS & MWe & $\begin{array}{c}\text { ANNUAL } \\
\text { BTU } \\
\text { EQUIV } \\
\left(\begin{array}{ll}x & 10^{9}\end{array}\right)\end{array}$ & $\begin{array}{l}\text { YEAR ON-LINE/ } \\
\text { OPERATIONAL }\end{array}$ \\
\hline SNAKE RIVER PLAIN & $\begin{array}{l}\text { Raft River } \\
\text { Rexburg }\end{array}$ & $\begin{array}{l}\text { Mr. Crook } \\
\text { Unknown (Fish Farm) } \\
\text { Unknown (Ethanol Plant) } \\
\text { Unknown (Ethanol Plant) } \\
\text { Madison County Energy Commission }\end{array}$ & $\begin{array}{l}- \\
- \\
- \\
-\end{array}$ & $\begin{array}{l}\text { PR } \\
\text { OP } \\
\text { PR } \\
\text { PR } \\
\text { UC }\end{array}$ & $\begin{array}{l}- \\
- \\
- \\
-\end{array}$ & $\begin{array}{c}13.9 \\
5 \\
300 * \\
30 * \\
780\end{array}$ & $\begin{array}{l}\mathrm{U} \\
\mathrm{U} \\
1982 \\
\mathrm{U} \\
1981\end{array}$ \\
\hline OWYHEE UPLAND & $\begin{array}{l}\text { Buhl } \\
\text { Kimberly } \\
\text { Miracle Hot } \\
\text { Springs } \\
\text { Twin Falls }\end{array}$ & $\begin{array}{l}\text { Archibald's } \\
\text { Fish Breeders of Idaho } \\
\text { Unknown } \\
\text { Unknown } \\
\text { Valley Trout Farms } \\
\text { Valley Trout Farms } \\
\text { Agricultural Exper. Station } \\
\text { J. H. Henry Produce } \\
\text { Unknown (Resort) } \\
\text { College of Southern Idaho } \\
\text { D. Armstrong } \\
\text { Western Resource Recovery }\end{array}$ & $\begin{array}{l}- \\
- \\
- \\
- \\
- \\
- \\
- \\
- \\
- \\
- \\
- \\
-\end{array}$ & $\begin{array}{l}\text { OP } \\
\text { OP } \\
\text { OP } \\
\mathrm{PR} \\
\text { OP } \\
\mathrm{PR} \\
\mathrm{PR} \\
\mathrm{PR} \\
\mathrm{OP} \\
\mathrm{PR} \\
\mathrm{PR} \\
\mathrm{PR}\end{array}$ & $\begin{array}{l}- \\
- \\
- \\
- \\
- \\
- \\
- \\
- \\
- \\
- \\
- \\
-\end{array}$ & $\begin{array}{r}1 \\
788 \\
1 \\
100 * \\
100 * \\
60 * \\
1 * \\
300 \\
.5 \\
3 \\
12^{*} \\
360 *\end{array}$ & $\begin{array}{c}\mathrm{U} \\
1974 \\
\mathrm{U} \\
\mathrm{U} \\
\mathrm{U} \\
\mathrm{U} \\
\mathrm{U} \\
\mathrm{U} \\
\mathrm{U} \\
\mathrm{19} \\
\mathrm{U} \\
\mathrm{U}\end{array}$ \\
\hline
\end{tabular}


STATE:_IDAHO

TABLE 11 (Concluded)

ELECTRIC POWER AND DIRECT USE DEVELOPMENT ACTIVITY

\begin{tabular}{|c|c|c|c|c|c|c|c|}
\hline REGION & $\begin{array}{l}\text { AREAS /S ITES } \\
\text { INCLUDED }\end{array}$ & DEVELOPER & UTILITY & STATUS & MWe & $\begin{array}{l}\text { ANNUAL } \\
\text { BTU } \\
\text { EQUIV } \\
\left(x \quad 10^{9}\right)\end{array}$ & $\begin{array}{l}\text { YEAR ON-LINE/ } \\
\text { OPERATIONAL }\end{array}$ \\
\hline \multirow{11}{*}{$\begin{array}{l}\text { HIGH LAVA PLAINS / } \\
\text { MALHEUR-BOISE BASIN }\end{array}$} & \multirow[t]{10}{*}{ Boise } & Capito1 Ma11 & - & UC & - & 63 & 1983 \\
\hline & & Edwards & - & OP & - & 1 & $\mathrm{U}$ \\
\hline & & Elks Rehabilitation Hospital & - & $\mathrm{PR}$ & - & 10 & $\mathrm{U}$ \\
\hline & & Hunt Brothers Floral & - & op & - & 1 & $\mathrm{U}$ \\
\hline & & State of Idaho & - & $\mathrm{OP}$ & - & 11 & 1977 \\
\hline & & V.A. Hospital & - & PR & - & 10 & 1983 \\
\hline & & Warm Springs Hollow & - & $\mathrm{UC}$ & - & 207 & 1982 \\
\hline & & Warm Springs Water District & - & $\mathrm{OP}$ & - & 80 & 1900 \\
\hline & & Warm Springs Water District & - & $\mathrm{OP}$ & - & 400 & 1920 \\
\hline & & Warm Springs Water District & - & $\mathrm{OP}$ & - & 320 & 1970 \\
\hline & Mountain Home & U. S. Air Force & - & $\mathrm{PR}$ & - & .2 & $\mathrm{U}$ \\
\hline \multirow[t]{5}{*}{ SNAKE RIVER PLAIN } & \multirow{7}{*}{$\begin{array}{l}\text { Pocate11o } \\
\text { Raft River KGRA }\end{array}$} & Great Western Malting & - & $\mathrm{PR}$ & - & $100 *$ & $\mathrm{U}$ \\
\hline & & INEL/EG\&G & - & UC & 5 & - & 1981 \\
\hline & & Bechtel Nationa1 & - & $\mathrm{PR}$ & - & $1200 *$ & $\mathrm{U}$ \\
\hline & & EG\&G/Univ. Idaho & - & $\mathrm{PR}$ & - & $100 *$ & $\mathrm{U}$ \\
\hline & & McDonalds/EG\&G & - & $\mathrm{PR}$ & - & $100 *$ & $\mathrm{U}$ \\
\hline Total, Operating & & & & & - & 1708.5 & \\
\hline Total, Other & & & & & 5 & 3750.1 & \\
\hline
\end{tabular}




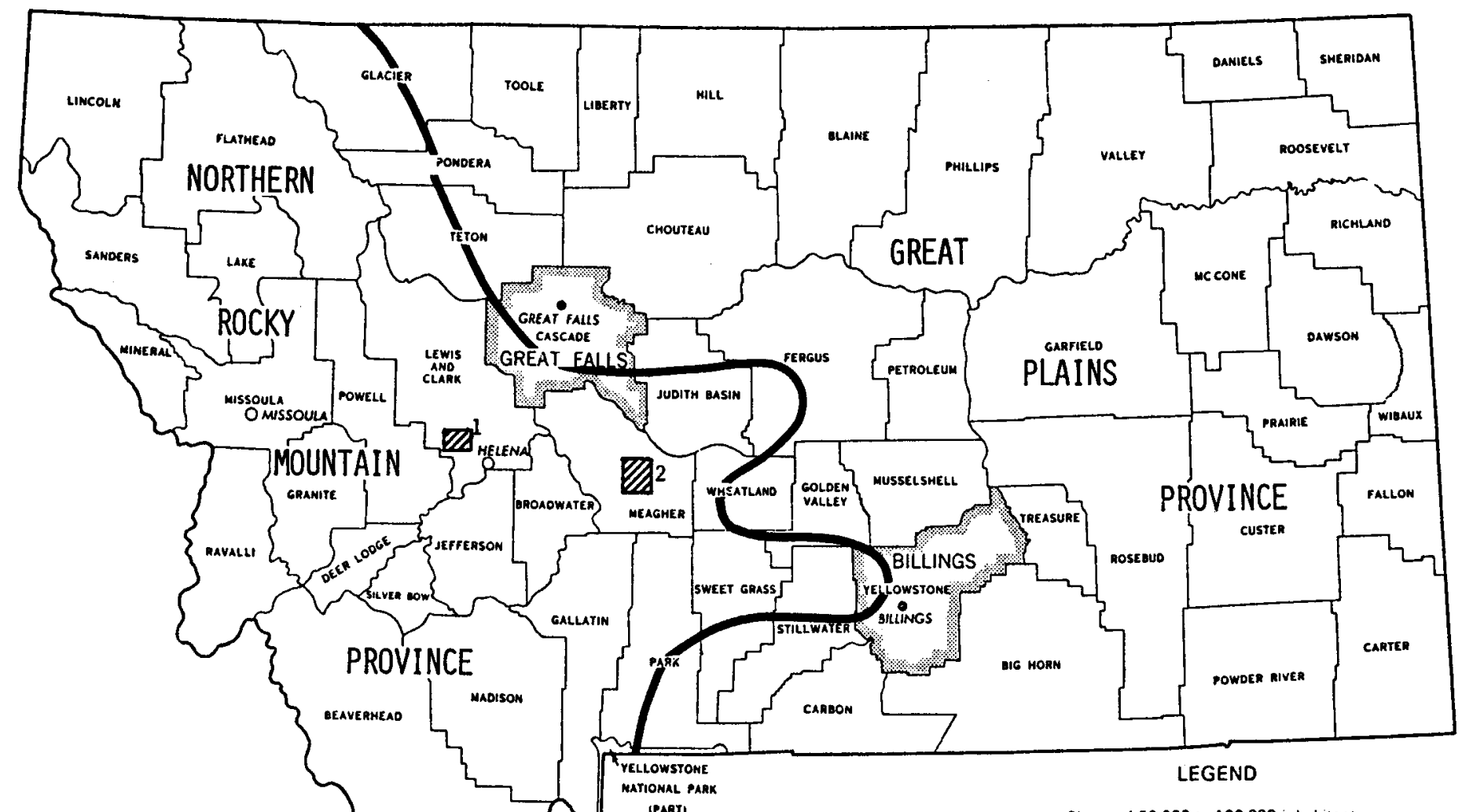

WA Principal Geothermal Areas

1. Marysville Direct Heat Project

2. White Sulphur Springs Direct Heat Project

- Places of 50.000 to 100.000 inhabrants
o Places of 25,000 10 50.000 inhabitants outside SMSA's 1 Strandard Meiroopolitan 
STATE:_MONTANA

TABLE 12

LANDS LEASED AND/OR EXPLORED

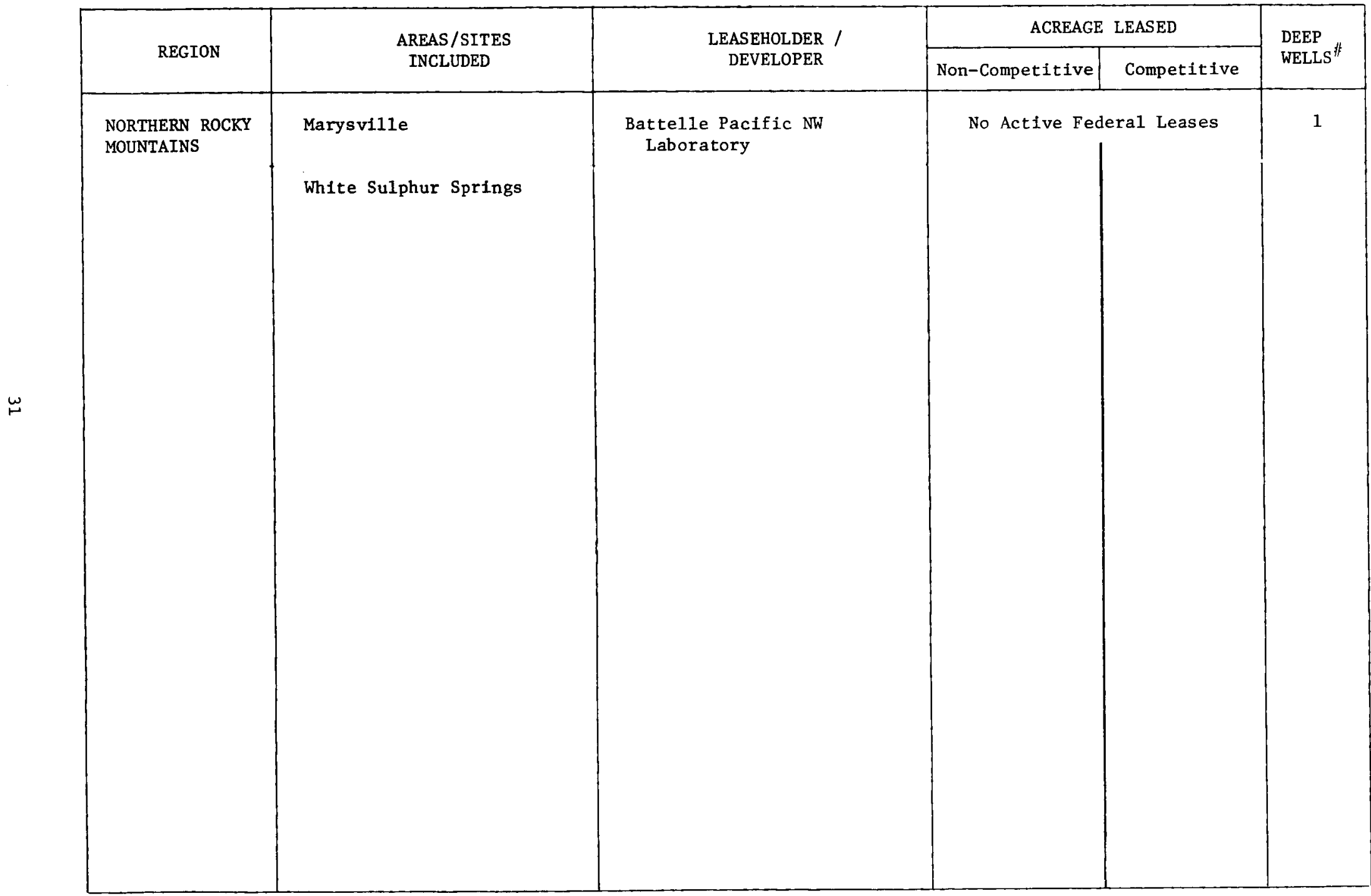

\#Wells over 2000 feet known to be producible. 
TABLE 13

ELECTRIC POWER AND DIRECT USE DEVELOPMENT ACTIVITY
OP - Operating

- Unknown

\begin{tabular}{|c|c|c|c|c|c|c|c|}
\hline REGION & $\begin{array}{l}\text { AREAS/SITES } \\
\text { INCLUDED }\end{array}$ & DEVELOPER & UTILITY & STATUS & MWe & $\begin{array}{l}\text { ANNUAL } \\
\text { BTU } \\
\text { EQUIV } \\
\left(\begin{array}{ll}x & 10^{\circ}\end{array}\right)\end{array}$ & $\begin{array}{l}\text { YEAR ON LINE/ } \\
\text { OPERATIONAL }\end{array}$ \\
\hline $\begin{array}{l}\text { NORTHERN ROCKY MOUNTAINS } \\
\text { Total, Operat ing } \\
\text { Total, Other }\end{array}$ & $\begin{array}{l}\text { White Sulphur } \\
\text { Springs }\end{array}$ & $\begin{array}{l}\text { First National Bank } \\
\text { White Sulphur Springs } \\
\text { Motel Spa }\end{array}$ & & $\begin{array}{l}\mathrm{OP} \\
\mathrm{OP}\end{array}$ & $\begin{array}{l}- \\
- \\
- \\
-\end{array}$ & $\begin{array}{r}.5 \\
.5 \\
1.0 \\
-\end{array}$ & $\begin{array}{c}1980 \\
\mathrm{U}\end{array}$ \\
\hline
\end{tabular}


Principal leaseholders in Nevada are o'Brien Resources, Atlantic Richfield, and Amax, al1 leasing primarily in Dixie Valley, as well as Aminoil and Sunedco, Anadarko, Phillips, and the American Geothermal Drilling Company. The majority of competitive leases in the identified geothermal resource areas are held by Aminoil/Sunedco, Phillips, and Republic Geothermal.

Table 14 contains more detailed information about the leasing and exploration activity in the state.

Direct Heat Applications

A major use of geothermal direct heat in Nevada is for residential and district space heating. A number of projects are underway at Steamboat Springs, where three schools and a police and fire station are heated geothermally, and in the city of Reno, where several district heating projects are proposed or under construction. The Hydrothermal Energy Corporation is developing geothermal resources for residential space and water heating for a large apartment complex and for the MGM Grand Hotel. A large community in Reno is already being heated geothermally and a geothermal district heating system for a 112-acre subdivision is currently under construction.

Ethanol plants are proposed by developers in the Humboldt area, in the Brady-Hazen KGRA, and Wabuska Hot Springs. An ethanol plant is currently being operated by Tad's Enterprises at Yerington.

Electric Power Development

The Northern Nevada Utility Group (NORNEV), a group of five utilities (Sierra Pacific Power Company, Sacramento Municipal Utility District, Eugene Water and Electric Board, Pacific Power and Light Company, and Portland General Electric) has proposed construction of a 10 MWe power plant at Dixie Valley. Two other 10 MWe plants at Steamboat Springs and Beowawe may follow. Experimental power plant permitting procedures are under way at Dixie Valley, Beowawe and Steamboat Springs. NORNEV will use the test data in the design of their first 10 MWe unit to be constructed in Nevada in the next two years.

Electric power and direct heat activities are summarized in Table 15.

Recent Major Activities

\section{- Nevada Legislation Generates Controversy}

A comprehensive bill intended to define geothermal energy and encourage utilities to develop alternative energy sources has polarized utility companies and consumer advocates around ratemaking policies suggested by the bill. One of the controversial sections of the bill would allow utilities developing alternative energy sources such as wind, solar, and geothermal power to bill consumers for construction work in progress, recover costs from consumers in the case of project failure, liberalize inter-utility power sales, and peg prices charged for alternative energy to conventional sources such as oil, coal, and natural gas.

Source: SAN Monthly Report, 5/8/81.

NEW MEXICO

New Mexico contains numerous low- to moderate-temperature geothermal resources suitable for direct heat applications, as well as some high-temperature resources in the Baca ranch area in the Jemez Mountains. Development of this area has been and promises in the future to be controversial. The issue of infringement on the religious rights of the indigenous Pueblo Indians by power plant development in the area has already been raised. In addition, fear of encroaching upon the scenic beauty of the mountain area is likely to create opposition to power projects in the future. Legislators have already tried to pass bills protecting the area from proliferation of geothermal power plants.

\section{Leasing and Exploration}

Figure 9 is an index map of the six principal geothermal resource areas in New Mexico. Although 'the majority of the sites lie within the Rio Grande Rift, deep producible wells have been completed in only one of these areas (Baca Location No. 1 KGRA).

Most of the leases are in or around the Lightning Dock KGRA and in the Baca Location No. 1 KGRA, site of a proposed 50 MWe power plant. Principal competitive leaseholders are Amax, Phillips, and Aminoil. Overall, Amax has the largest amount of land under lease in New Mexico. 


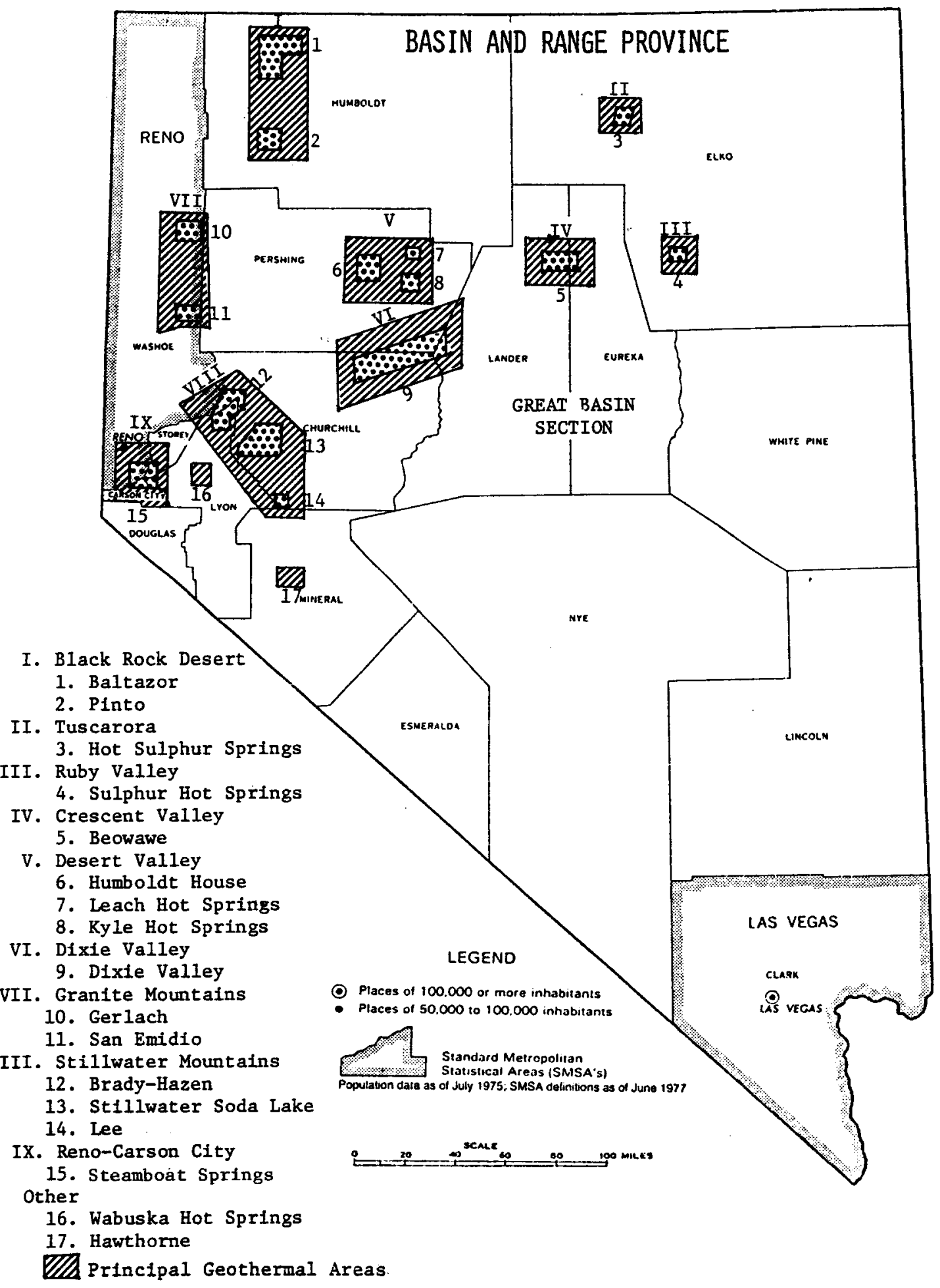

Figure 8

Principal Geothermal Resource Areas in Nevada 
TABLE 14

LANDS LEASED AND/OR EXPLORED

\begin{tabular}{|c|c|c|c|c|c|}
\hline \multirow{2}{*}{ REGION } & \multirow{2}{*}{$\begin{array}{l}\text { AREAS/SITES } \\
\text { INCLUDED }\end{array}$} & \multirow{2}{*}{$\begin{array}{l}\text { LEASEHOLDER* / } \\
\text { DEVELOPER }\end{array}$} & \multicolumn{2}{|c|}{ ACREAGE LEASED } & \multirow{2}{*}{$\begin{array}{l}\text { DEEP } \\
\text { WELLS }\end{array}$} \\
\hline & & & Non-Competitive & Competitive & \\
\hline BLACK ROCK DESERT & $\begin{array}{l}\text { Baltazor } \\
\text { Pinto }\end{array}$ & $\begin{array}{l}\text { Continental Geothermal } \\
\text { Corp. } \\
\text { Earth Power } \\
\text { Therma1 Resources, Inc. } \\
\text { U.S. Geothermal Corp. } \\
\text { Private Individuals } \\
\end{array}$ & $\begin{array}{r}7,363 \\
12,151 \\
13,506 \\
10,723 \\
14,456 \\
\end{array}$ & $\begin{array}{l}1,253 \\
5,537 \\
7,975\end{array}$ & \\
\hline DESERT VALLEY & $\begin{array}{l}\text { Humboldt House } \\
\text { Leach } \\
\text { Kyle }\end{array}$ & $\begin{array}{l}\text { Aminoil USA, Inc. } \\
\text { Aminoil USA \& Sunoco } \\
\text { Development Corp. } \\
\text { American Geothermal } \\
\text { Drilling Co. } \\
\text { Chevron USA, Inc. } \\
\text { Phillips Petroleum Co. } \\
\text { Union 011 } \\
\text { Private Individuals }\end{array}$ & $\begin{array}{r}16,419 \\
11,016 \\
18,695 \\
\\
8,949 \\
3,700 \\
51,095 \\
\end{array}$ & $\begin{array}{r}12,246 \\
2,400\end{array}$ & \\
\hline $\begin{array}{l}\text { EAST SLOPE } \\
\text { GRANITE MOUNTAINS }\end{array}$ & $\begin{array}{l}\text { Great Boiling Springs - } \\
\text { Gerlach } \\
\text { San Emidio }\end{array}$ & $\begin{array}{l}\text { Aminoil USA, Inc. } \\
\text { Calvert Drilling } \\
\text { Occidental Geothermal, } \\
\text { Inc. } \\
\text { Sunoco Energy Research } \\
\& \text { Development Corp. } \\
\text { Private Individuals } \\
\end{array}$ & $\begin{array}{r}2,271 \\
1,280 \\
24,178 \\
\end{array}$ & $\begin{array}{l}5,123 \\
6,616 \\
6,245\end{array}$ & 1 \\
\hline $\begin{array}{l}\text { STILLWATER } \\
\text { MOUNTAINS }\end{array}$ & $\begin{array}{l}\text { Brady-Hazen } \\
\text { Stillwater-Soda Lake } \\
\text { Lee }\end{array}$ & $\begin{array}{l}\text { Andarko Production Co. } \\
\text { Chevron Oil Co. \& Phillips } \\
\text { Petroleum } \\
\text { Chevron USA, Inc. } \\
\text { Earth Energy } \\
\text { Geoproducts Corp. } \\
\text { Geothermal Resources } \\
\text { International } \\
\text { Magma Power \& Union Oil } \\
\text { Co. } \\
\text { Phillips Petroleum Co. } \\
\text { Occidental Geotherma1, } \\
\text { Inc. }\end{array}$ & $\begin{array}{l}3,302 \\
5,703\end{array}$ & $\begin{array}{r}2,480 \\
1,852 \\
13,426\end{array}$ & 1 \\
\hline
\end{tabular}

${ }^{*}$ Federal 1 ands only. 
STATE: NEVADA

TABLE 14 (Continued)

LANDS LEASED AND/OR EXPLORED

\begin{tabular}{|c|c|c|c|c|c|}
\hline \multirow{2}{*}{ REGION } & \multirow{2}{*}{$\begin{array}{l}\text { AREAS/STTES } \\
\text { INCLUDED }\end{array}$} & \multirow{2}{*}{$\begin{array}{l}\text { LEASEHOLDER* / } \\
\text { DEVELOPER }\end{array}$} & \multicolumn{2}{|c|}{ ACREAGE LEASED } & \multirow{2}{*}{$\begin{array}{l}\text { DEEP } \\
\text { WELLS }\end{array}$} \\
\hline & & & Non-Competitive & Competitive & \\
\hline $\begin{array}{l}\text { STILLWATER } \\
\text { MOUNTAINS } \\
\text { (Continued) }\end{array}$ & & $\begin{array}{l}\text { Sulphur River Explora- } \\
\text { tion, Inc. } \\
\text { Supron Energy Corp. } \\
\text { Thermal Power Co. } \\
\text { Union Oil Co. \& } \\
\text { Magma Energy, Inc. } \\
\text { Union Oil of Calif. } \\
\text { Private Individuals }\end{array}$ & $\begin{array}{r}3,200 \\
4,385 \\
5,012 \\
15,430\end{array}$ & $\begin{array}{r}5,120 \\
2,561 \\
1,505 \\
\\
643 \\
1,269\end{array}$ & \\
\hline RUBY VALLEY & Sulphur Hot Springs & $\begin{array}{l}\text { Thermex Co. } \\
\text { Union Oil of California }\end{array}$ & $\begin{array}{r}2,680 \\
745\end{array}$ & 3,823 & \\
\hline TUSCARORA & Hot Sulphur Springs & & No Active Fec & eral Leases & \\
\hline CRESCENT VALLEY & Beowawe & $\begin{array}{l}\text { Chevron USA, Inc. } \\
\text { Getty Oil Co. } \\
\text { Supron Energy Corp. } \\
\text { Private Individuals }\end{array}$ & $\begin{array}{r}5,699 \\
1,287 \\
640 \\
1,341\end{array}$ & $\begin{array}{l}6,250 \\
4,940 \\
1,938\end{array}$ & 1 \\
\hline $\begin{array}{l}\text { RENO-CARSON } \\
\text { CITY }\end{array}$ & Steamboat Springs & $\begin{array}{l}\text { Earth Power Corp. } \\
\text { Gulf Mineral Resources } \\
\text { Co. } \\
\text { Pacific Energy Corp. } \\
\text { Phillips Petroleum } \& \\
\text { Gulf Oil Corp. } \\
\text { Private Individuals }\end{array}$ & $\begin{array}{l}1,011 \\
2,028 \\
2,559 \\
3,403\end{array}$ & 1,548 & 1 \\
\hline DIXIE VALLEY & Dixie Valley & $\begin{array}{l}\text { Amax Exploration, Inc. } \\
\text { Atlantic Richfield Co. } \\
\text { Champlin Petroleum Co. } \\
\text { Geothermal Resources } \\
\text { International } \\
\text { Getty Oil Co. } \\
\text { J. W. Hughes \& Southland } \\
\text { Power Co. } \\
\text { Hughes, et. al. and } \\
\text { Sunoco Energy Develop- } \\
\text { ment Corp. } \\
\text { MCR Geothermal Corp. }\end{array}$ & $\begin{array}{r}16,021 \\
14,996 \\
5,104 \\
7,998 \\
7,712 \\
2,559 \\
5,121 \\
12,789\end{array}$ & $\begin{array}{r}27,892 \\
2,560\end{array}$ & \\
\hline
\end{tabular}


STATE: NEVADA

TABLE 14 (Concluded)

LANDS LEASED AND/OR EXPLORED

\begin{tabular}{|c|c|c|c|c|c|}
\hline \multirow{2}{*}{ REGION } & \multirow{2}{*}{$\begin{array}{l}\text { AREAS/SITES } \\
\text { INCLUDED }\end{array}$} & \multirow{2}{*}{$\begin{array}{l}\text { LEASEHOLDER* / } \\
\text { DEVELOPER }\end{array}$} & \multicolumn{2}{|c|}{ ACREAGE LEASED } & \multirow{2}{*}{$\begin{array}{l}\text { DEEP } \\
\text { WELLS }\end{array}$} \\
\hline & & & Non-Competitive & Competitive & \\
\hline $\begin{array}{l}\text { DIXIE VALLEY } \\
\text { (Continued) }\end{array}$ & & $\begin{array}{l}\text { Mobil Oil Corp. } \\
\text { O'Brien Resources Corp. } \\
\text { Occidental Geothermal, } \\
\text { Inc. } \\
\text { Onaping Energy \& } \\
\text { Resources, Inc. } \\
\text { Phillips Petroleum Co. } \\
\text { Quest Energy Ltd. } \\
\text { Republic Geothermal, } \\
\text { Inc. } \\
\text { Southland Royalty Co. } \\
\text { Southland Royalty Co. } \\
\text { \& Champlin Petroleum } \\
\text { Southland Royalty Co. } \\
\text { \& Thermal Power Co. } \\
\text { Southland, Thermal } \\
\text { Power \& J.W. Hughes } \\
\text { Sunoco Energy Develop- } \\
\text { ment Co. } \\
\text { Supron Energy Corp. } \\
\text { Union Oil of Calif. } \\
\text { Private Individuals }\end{array}$ & $\begin{array}{r}5,066 \\
36,631 \\
5,119 \\
4,085 \\
12,752 \\
3,813 \\
1,280 \\
11,253 \\
2,559 \\
8,798 \\
4,477 \\
9,870 \\
3,806 \\
1,280 \\
124,129\end{array}$ & $\begin{array}{r}13,523 \\
1,600\end{array}$ & 2 \\
\hline OTHER & $\begin{array}{l}\text { Wabuska HS (Lyon County) } \\
\text { Hawthorne (Mineral County) }\end{array}$ & & No Active Fed & ral Leases & \\
\hline
\end{tabular}


STATE: NEVADA

TABLE 15

ELECTRIC POWER AND DIRECT USE DEVELOPMENT ACTIVITY
Code: UC" - Under Construction

PR - Proposed

OP - Operating

U - Unknown

\begin{tabular}{|c|c|c|c|c|c|c|c|}
\hline REGION & $\begin{array}{l}\text { AREAS/SITES } \\
\text { INCLUDED }\end{array}$ & DEVELOPER & UTILITY & STATUS & MWe & $\begin{array}{l}\text { ANNUAL } \\
\text { BTU } \\
\text { EQUIV } \\
\left(\begin{array}{ll}x & 10^{9}\end{array}\right)\end{array}$ & $\begin{array}{l}\text { YEAR ON LINE/ } \\
\text { OPERATIONAL }\end{array}$ \\
\hline DESERT VALLEY & Humboldt & $\begin{array}{l}\text { Unknown (Space Heat) } \\
\text { Nevada Green } \\
\text { Desert Research Institute }\end{array}$ & $\begin{array}{l}- \\
-\end{array}$ & $\begin{array}{l}\text { OP } \\
\text { OP } \\
\text { PR }\end{array}$ & $\begin{array}{l}- \\
- \\
-\end{array}$ & $\begin{array}{l}1 \\
.5 * \\
60 *\end{array}$ & $\begin{array}{c}\mathrm{U} \\
1979 \\
\mathrm{U}\end{array}$ \\
\hline STILLWATER MOUNTAINS & $\begin{array}{l}\text { Brady-Hazen } \\
\text { Stillwater }\end{array}$ & $\begin{array}{l}\text { Geothermal Food Processors } \\
\text { Grace Geothermal } \\
\text { Geothermal Food Processors } \\
\text { Unknown (Space Heat) }\end{array}$ & $\begin{array}{l}- \\
- \\
-\end{array}$ & $\begin{array}{l}\text { PR } \\
P R \\
\text { OP } \\
\text { OP }\end{array}$ & $\begin{array}{l}- \\
- \\
-\end{array}$ & $\begin{array}{c}600 * \\
600 * \\
160 \\
1\end{array}$ & $\begin{array}{l}1982 \\
1982 \\
1979 \\
1912\end{array}$ \\
\hline CRESCENT VALLEY & Beowawe & Half Circle Ranch & - & $\mathrm{PR}$ & - & 30 & $\mathrm{U}$ \\
\hline RENO-CARSON CITY & $\begin{array}{c}\text { Steamboat } \\
\text { Springs }\end{array}$ & $\begin{array}{l}\text { ABC Concrete Production } \\
\text { Double Diamond Development } \\
\text { Unknown (District Heating) } \\
\text { Unknown } \\
\text { Unknown } \\
\text { City of Reno } \\
\text { Damonte Ranch } \\
\text { Double Diamond Development } \\
\text { Hydrothermal Energy Corporation } \\
\text { MGM Grand Hotel } \\
\text { Moana Pool } \\
\text { The Pepper Mill }\end{array}$ & $\begin{array}{l}- \\
- \\
- \\
- \\
- \\
- \\
- \\
- \\
- \\
- \\
- \\
-\end{array}$ & $\begin{array}{l}\text { UC } \\
\text { UC } \\
\text { PR } \\
\text { OP } \\
\text { OP } \\
\text { PR } \\
\text { PR } \\
\text { UC } \\
\text { UC } \\
\text { UC } \\
\text { OP } \\
\text { OP }\end{array}$ & $\begin{array}{l}- \\
- \\
- \\
- \\
- \\
- \\
- \\
- \\
- \\
- \\
- \\
-\end{array}$ & $\begin{array}{r}100 * \\
5 * \\
5 * \\
.5 \\
.2 \\
5 * \\
1200 * \\
1600 * \\
5 * \\
100 * \\
.5 * \\
1 *\end{array}$ & $\begin{array}{c}\text { U } \\
1981 \\
U \\
U \\
1979 \\
U \\
U \\
1982 \\
1981 \\
U \\
U \\
U\end{array}$ \\
\hline
\end{tabular}

*Annual energy use is a rough estimate.

\#For direct heat projects, construction begins with preliminary development activities such as exploratory drilling. 
STATE: NEVADA

TABI, 15 (Concluded)

ELECTRIC POWER AND DIRECT USE DEVELOPMENT ACTIVITY

\begin{tabular}{|c|c|c|c|c|c|c|c|}
\hline REGION & $\begin{array}{l}\text { AREAS/SITES } \\
\text { INCLUDED }\end{array}$ & DEVELOPER & UTILITY & STATUS & MWe & $\begin{array}{l}\text { ANNUAL } \\
\text { BTU } \\
\text { EQUIV } \\
\left(x \quad 10^{9}\right)\end{array}$ & $\begin{array}{l}\text { YEAR ON-LINE } \\
\text { OPERATIONAL }\end{array}$ \\
\hline $\begin{array}{l}\text { RENO-CARSON CITY } \\
\text { (Continued) }\end{array}$ & $\begin{array}{l}\text { Steamboat } \\
\text { Springs }\end{array}$ & $\begin{array}{l}\text { Unknown (Space Heating) } \\
\text { Veterans Hospital } \\
\text { Warren Properties } \\
\text { Explosives Engineering } \\
\text { Mark Twain Motel } \\
\text { Unknown }\end{array}$ & $\begin{array}{l}- \\
- \\
- \\
- \\
-\end{array}$ & $\begin{array}{l}\text { OP } \\
\text { PR } \\
\text { UC } \\
\text { OP } \\
\text { OP } \\
\text { OP }\end{array}$ & $\begin{array}{l}- \\
- \\
- \\
- \\
-\end{array}$ & $\begin{array}{r}15 * \\
1 * \\
32 * \\
5 * \\
.5 * \\
1\end{array}$ & $\begin{array}{l}\mathrm{U} \\
\mathrm{U} \\
\mathrm{U} \\
\mathrm{U} \\
\mathrm{U} \\
\mathrm{U}\end{array}$ \\
\hline DIXIE VALLEY & Dixie Valley & Phillips Petroleum & $\begin{array}{l}\text { Northern Nevada } \\
\text { Utility Group }\end{array}$ & PR & 10 & - & 1982 \\
\hline OTHER & $\begin{array}{l}\text { Wabuska Hot } \\
\text { Springs }\end{array}$ & $\begin{array}{l}\text { Alexander Dawson Company } \\
\text { Tad's Enterprises }\end{array}$ & - & $\begin{array}{l}\text { PR } \\
\text { OP }\end{array}$ & - & $\begin{array}{l}60 * \\
24 *\end{array}$ & $\begin{array}{c}\mathrm{U} \\
1980\end{array}$ \\
\hline $\begin{array}{l}\text { Total, Operating } \\
\text { Total, Other }\end{array}$ & & & & & - & $\begin{array}{r}210.2 \\
4403\end{array}$ & \\
\hline
\end{tabular}


Leasing and exploration activity is shown in Table 16.

\section{Direct Heat Applications}

Principal direct heat uses in New Mexico are commercial and residential space and water heating, and greenhousing. Three space heating projects are currently in use, two in Truth or Consequences at the Carrie Tingley Hospital and the Yucca Lodge and one at a lo-story bank building in Albuquerque. Commercial and residential space heating projects are under construction at Las Cruces and Truth or Consequences. These include a project to heat twelve buildings on the campus of New Mexico State University at Las Cruces, for which four wells have already been drilled, and space and water heating for a senior citizens' center in Truth or Consequences, where drilling has started. In addition, eight residential heating projects are proposed in Albuquerque, West Mesa, Las Cruces, and Truth or Consequences. Elsewhere in the state, three greenhouses are currently using geothermal heat in the Animas Valley and their developers/owners are proposing expansion of their geothermal operations.

\section{Electric Power Development}

In the Baca location No. 1 KGRA (Valles Caldera), a 50 MWe demonstration electric power plant ts proposed. The project is being funded by the Department of Energy, Union Oil of California and the Public Service Company of New Mexico. Well drilling for this project is continuing but plant construction is currently suspended until Union oil demonstrates its ability to produce an adequate supply of steam for the facility. Power on line is scheduled for 1984 .

Electric power and direct heat projects are summarized in Table 17.

Recent Major Activities

- New Mexico Bill to Halt PSC Review of Small Test Plants

A bill introduced in the New Mexico state legislature early this year would prevent the State Public Service Commission (PSC) from reviewing small demonstration power plants, possibly including the Baca geothermal project. The bill provides that "demonstration" plants or those "using new technology and producing no more than 50 MWe of power" will be reviewed only by the Environmental Improvement Division for air and water pollution controls. Though the PSC has completed hearings on the controversial Baca project, the case has not been settled and could possibly be affected by the legislation if enacted.

Source: Al buquerque Journal, 2/20/81

\section{- Geothermal Non-Proliferation Bill Rejected}

Another bill introduced in the state legislature was rejected by the Senate. This bill, which sought to prevent proliferation of geothermal power plants in the scenic Jemez Mountains, would have temporarily limited expansion of the 50 MWe power project at Baca.

\section{Source: Albuquerque Journal, $3 / 6 / 81$.}

\section{- Funding Proposed for NMSU Demonstration Project}

A bill before the New Mexico state legislature requests $\$ 29,000$ for a geothermal demonstration project proposed for New Mexico State University at Las Cruces. The funds would be combined with $\$ 125,000$ from the state Energy and Minerals Department and $\$ 336,000$ from the U.S. DOE. The total project cost is estimated at $\$ 1.29$ million. The funds would be used to complete the University's geothermal direct use project. The New Mexico legislature has appropriated about $\$ 2 \mathrm{million}$ a year for the past seven years to promote geothermal development in the state. If the current bill is approved, the project will use two geothermal wells on campus to supply space heating for eleven buildings and an outdoor pool.

$$
\text { Sources: GRC Bulletin, 5/81 PIC NGS, 3/13/81. }
$$

\section{NORTH DAKOTA}

High-temperature resources are not known to exist in North Dakota, though several direct heat projects using lower-temperature resources have been proposed.

\section{Leasing and Exploration}

The principal geothermal resource area in North Dakota is identified on the map in Figure 10. 


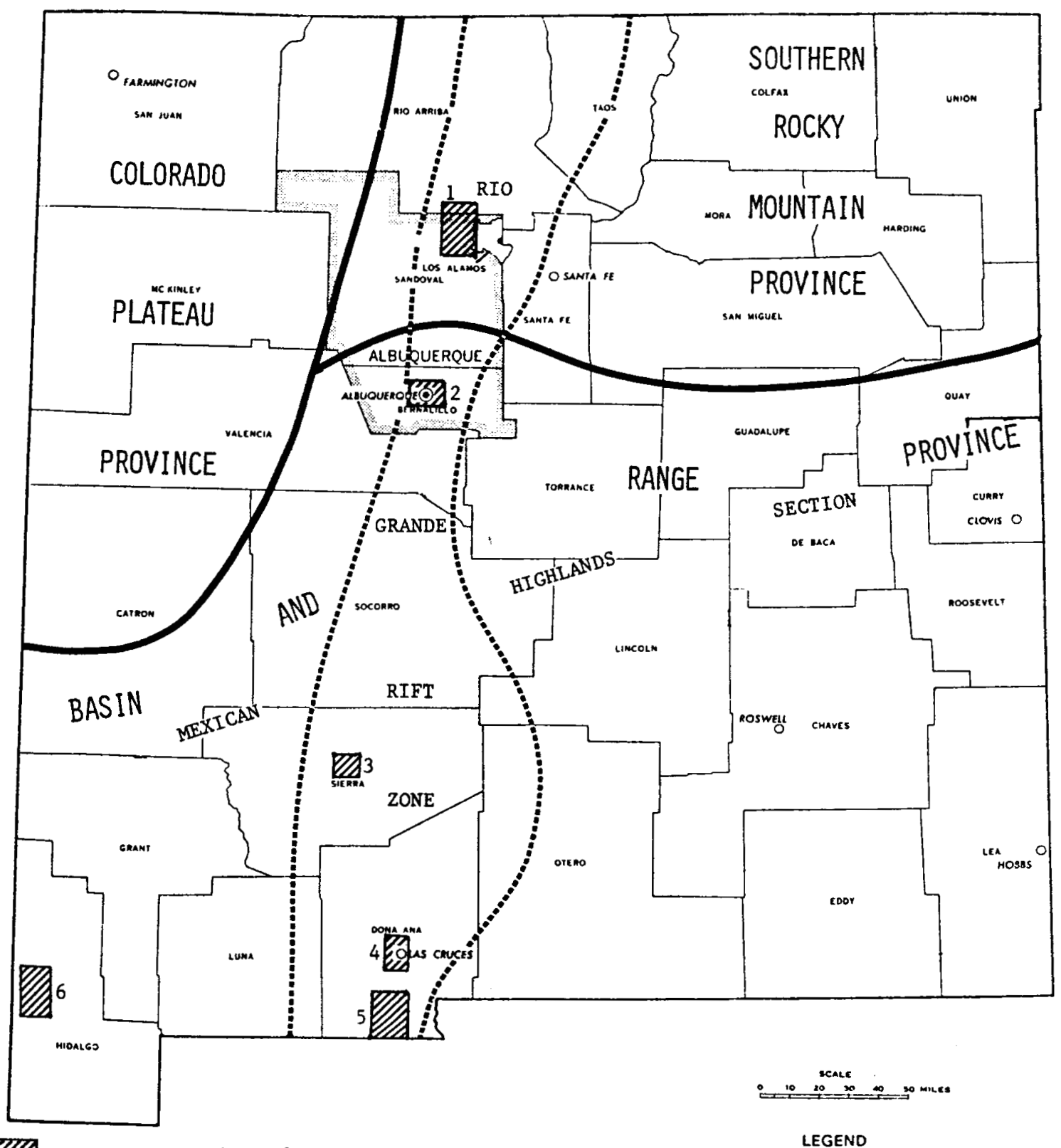

OIA Principal Geothermal Areas

1. Baca Location No. 1 KGRA

2. Albuquerque Direct Heat Project

3. Truth or Consequences Direct Heat Project

4. Las Cruces Direct Heat Project

5. Kilborne Hole KGRA

6. Lightning Dock KGRA

Places of 100,000 or mare inhabitante

P Places of 25.000 to 50.000 innebitanis outside SMSA's

Standard Meiropoliten
Stelistical Aroes (SMSA's)

Population data as of July :9/5. SMSA dofinutions as of June 1977

Figure 9

Principal Geothermal Resource Areas in New Mexico 
TABLE 16

LANDS LEASED AND/OR EXPLORED

\begin{tabular}{|c|c|c|c|c|c|}
\hline \multirow[t]{2}{*}{ REGION } & \multirow{2}{*}{$\begin{array}{l}\text { AREAS/SITES } \\
\text { INCLUDED }\end{array}$} & \multirow{2}{*}{$\begin{array}{l}\text { LEASEHOLDER*/ } \\
\text { DEVELOPER }\end{array}$} & \multicolumn{2}{|c|}{ ACREAGE LEASED } & \multirow{2}{*}{$\begin{array}{l}\text { DEEP } \\
\text { WELLS }\end{array}$} \\
\hline & & & Non-Competitive & Competitive & \\
\hline MEXICAN HIGHLANDS & Lightning Dock KGRA & $\begin{array}{l}\text { Amax/Earth Power } \\
\text { Amax Exploration } \\
\text { Aminoil } \\
\text { Chevron USA } \\
\text { Earth Power } \\
\text { Livingston International } \\
\text { Sunedco } \\
\text { Thermal Resources, Inc. } \\
\text { United States Geothermal } \\
\text { Corporation }\end{array}$ & $\begin{array}{r}2,989 \\
5,814 \\
534 \\
1,718 \\
2,560 \\
464 \\
1,285\end{array}$ & $\begin{array}{l}1,885 \\
6,580 \\
1,711 \\
3,175\end{array}$ & \\
\hline $\begin{array}{l}\text { MEXICAN HIGHLANDS/ } \\
\text { RIO GRANDE RIFT }\end{array}$ & $\begin{array}{l}\text { Kilbourne Hole KGRA } \\
\text { Las Cruces } \\
\text { Truth or Consequences } \\
\text { Albuquerque }\end{array}$ & Private Individuals & 7,206 & & \\
\hline $\begin{array}{l}\text { SOUTHERN ROCKY } \\
\text { MOUNTAINS / RIO } \\
\text { GRANDE RIFT }\end{array}$ & $\begin{array}{l}\text { Baca Location No. } 1 \text { KGRA } \\
\text { (Valles Caldera) }\end{array}$ & $\begin{array}{l}\text { Amax } \\
\text { Aminoil USA } \\
\text { Phillips Petroleum } \\
\text { Union Oil }\end{array}$ & & $\begin{array}{r}10,054 \\
10,481 \\
5,090\end{array}$ & 13 \\
\hline
\end{tabular}

* Federal lands only

\#Wells over 2000 feet known to be producible. 
TABLE 17

Code: UC ${ }^{\#}$ - Under Construction PR - Proposed OP - Operating

ELECTRIC POWER AND DIRECT USE DEVELOPMENT ACTIVITY

U - Unknown

\begin{tabular}{|c|c|c|c|c|c|c|c|}
\hline REGION & $\begin{array}{l}\text { AREAS/SITES } \\
\text { INCLUDED }\end{array}$ & DEVELOPER & UTILITY & STATUS & MWe & $\begin{array}{c}\text { ANNUAL } \\
\text { BTU } \\
\text { EQUIV. } \\
\left(\begin{array}{ll}x & 10^{9}\end{array}\right)\end{array}$ & $\begin{array}{l}\text { YEAR ON-LINE/ } \\
\text { OPERATIONAL }\end{array}$ \\
\hline $\begin{array}{l}\text { MEXICAN HIGHLANDS/ } \\
\text { RIO GRANDE RIFT }\end{array}$ & $\begin{array}{l}\text { Las Cruces } \\
\text { Truth or } \\
\text { Consequences } \\
\text { Albuquerque } \\
\\
\text { Lightning Dock } \\
\text { KGRA/Animas Valley }\end{array}$ & $\begin{array}{l}\text { Amdec Corporation } \\
\text { City of Las Cruces } \\
\text { Mesilla Valley Mal1 } \\
\text { New Mexico State University } \\
\text { Carrie Tingley Hospital } \\
\text { Geronimo Springs Museum } \\
\text { Kar1 Kortmeier } \\
\text { Randy Asbaugh } \\
\text { Senior Citizens Center } \\
\text { Yucca Lodge } \\
\text { Sandia Savings } \\
\text { University of New Mexico } \\
\text { High school } \\
\text { Residential Heating District } \\
\text { University of Albuquerque } \\
\text { West Mesa Apartments } \\
\text { Burgett Floral } \\
\text { Burgett Floral } \\
\text { Tom McCants } \\
\text { Tom McCants } \\
\text { Unknown } \\
\text { Unknown }\end{array}$ & $\begin{array}{l}- \\
- \\
- \\
- \\
- \\
- \\
- \\
- \\
- \\
- \\
- \\
- \\
- \\
- \\
- \\
- \\
- \\
- \\
- \\
-\end{array}$ & $\begin{array}{l}P R \\
P R \\
U C \\
U C \\
O P \\
U C \\
U C \\
P R \\
U C \\
O P \\
O P \\
P R \\
P R \\
P R \\
P R \\
P R \\
O P \\
P R \\
O P \\
U C \\
O P \\
P R\end{array}$ & $\begin{array}{l}- \\
- \\
- \\
- \\
- \\
- \\
- \\
- \\
- \\
- \\
- \\
- \\
- \\
- \\
- \\
- \\
- \\
- \\
- \\
- \\
-\end{array}$ & $\begin{array}{c}5 * \\
5 * \\
400 \\
400 \\
2 \\
1 * \\
2 \\
5 * \\
.2 \\
1 \\
5 \\
770 \\
1 * \\
5 * \\
52 \\
1 * \\
12 \\
600 \\
.5 \\
12 \\
101 * \\
600 *\end{array}$ & $\begin{array}{c}1981 \\
U \\
1981 \\
U \\
1980 \\
U \\
U \\
U \\
1981 \\
U \\
U \\
U \\
U \\
U \\
U \\
U \\
1978 \\
1984 \\
1967 \\
1981 \\
U \\
U\end{array}$ \\
\hline
\end{tabular}


STATE: NEW HIEXICO

TABLE 17 (Concluded)

ELECTRIC POWER AND DIRECT USE DEVELOPMENT ACTIVITY
Code: $\mathrm{UC}^{\#}$ - Under Construction

PR - Proposed

OP - Operating

$\mathrm{U}$ - Unknown

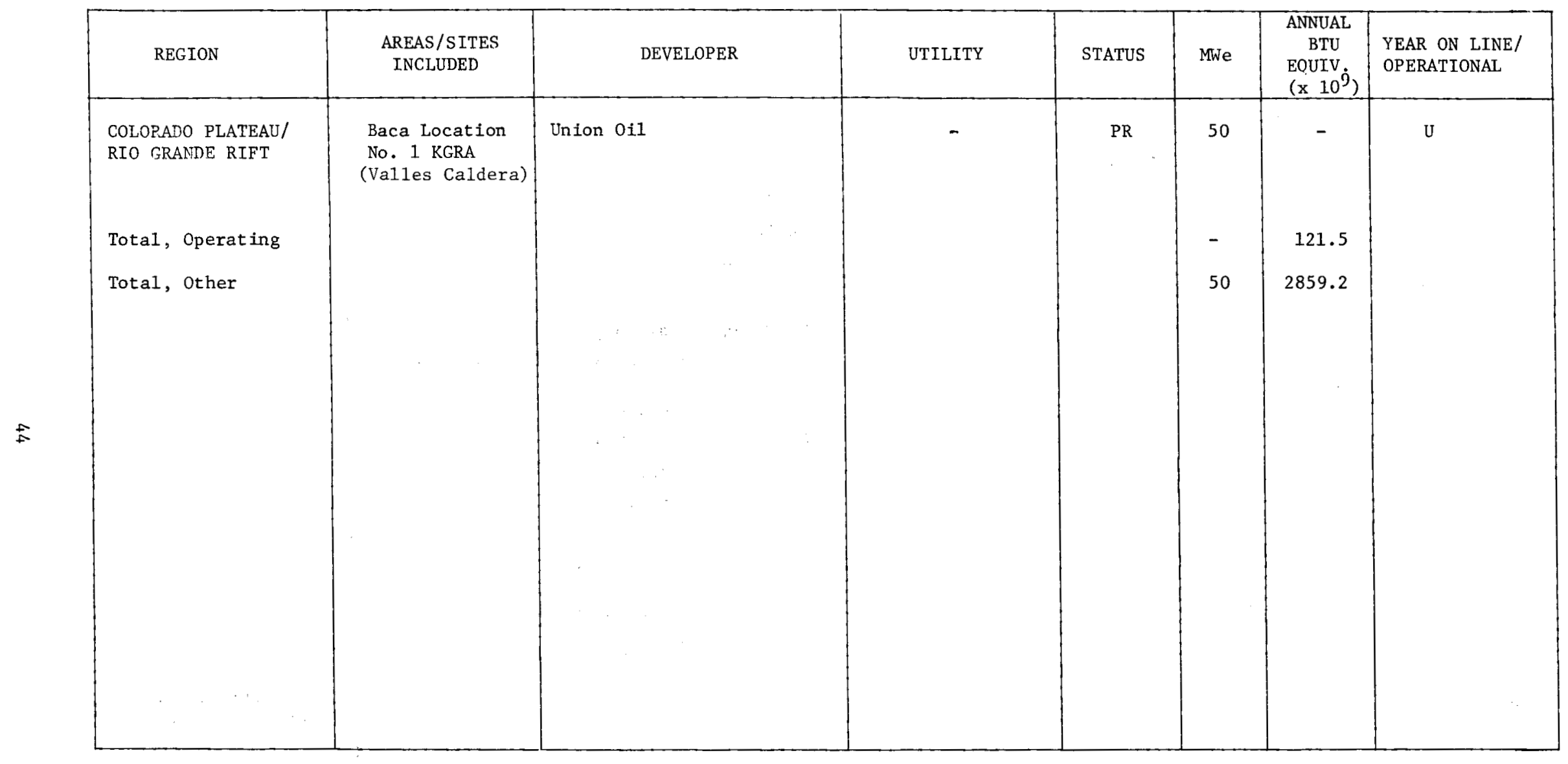

*Annual energy use is a rough estimate.
\#For direct heat projects, construction begins with preliminary development activities such as exploratory drilling. 
As yet, no federal lands have been leased for geothermal development, and there are no completed deep geothermal wells.

\section{Direct Heat Applications}

Five projects have been proposed in the Bismarck area, most of which are for residential and commercial space heating, including heating of the central business district. A local ski resort is considering using the geothermal energy for making snow. These projects are 1 isted in Table 18 .

\section{OREGON}

Geothermal resources have been used in Oregon since the turn of the century, primarily for heating of residences in Klamath Falls. The state is taking new interest in its geothermal resources, and has formed an alternative energy commission, which has initiated a statewide planning program. The Alvord Valley and Crump Geysers areas have received attention by industry in the last year, marked by the sale of competitive leases in the area.

\section{Leasing and Exploration}

Although there are many geothermal resource areas in the state of Oregon (Figure 11), no deep producible wells have been completed.

Major leaseholders in Oregon are Amax, the Rosewood Corp., California Geothermal, Placer Amex, Anadarko, and Getty 0il. Principal competitive leaseholders are Anadarko, Getty Oil, and Chevron USA. Most of the competitive leases are in the Alvord and Crump Geysers KGRAs. Table 19 summarizes the leasing activity in the state.

\section{Direct Heat Applications}

Geothermal direct heat is being used in oregon for residential and district heating, greenhousing and aquaculture, ethanol production and various other industrial processes.

The city of Klamath Falls has used geothermal resources for heating of residences since 1900; geothermal direct uses in the Klamath $\mathrm{Falls}$ area have since been expanded to include heating of more residences, commercial buildings, greenhouses, prawn raising and snow melting. Projects currently in operation in Klamath Falls include nine separate residential and commercial space heating projects, two greenhouses, two prawn-raising ventures, and snow melting on state roads. Projects to provide space heating to an elementary school and additional district heating to the city are currently under construction. Proposed projects include seven more residential/commercial space heating projects, an ethanol plant, and a sewage treatment plant.

Lakeview is using geothermal resources for greenhouse heating and aquaculture. A project to heat 71 downtown buildings and an industrial park is currently under construction. In addition, five projects have been proposed, including an ethanol plant and a wood chip drying operation.

Vale Hot Springs and nearby Adrian are now operating two ethanol plants and heating a YMCA. Homeowners have been using geothermal resources for heating since 1940. Another ethanol plant at Vale Hot Springs is proposed, as are agricultural and industrial process heat projects by a mushroom producing firm and a cattle company.

Four projects, including an ethanol plant, are in operation at Hot Lake and Medical Hot Springs in the Central Highlands region; the town of La Grande is proposing three separate cominercial and residential space heating projects.

These projects are detailed in Table 20 .

\section{SOUTH DAKOTA}

South Dakota's resources are in the low- to moderate-temperature range. They are being used for several direct heat applications.

\section{Leasing and Exploration}

A deep producible well has been completed at each of the principal geothermal areas in South Dakota (Figure 12, Table 21). Currently, there are no federal leases in the state. 


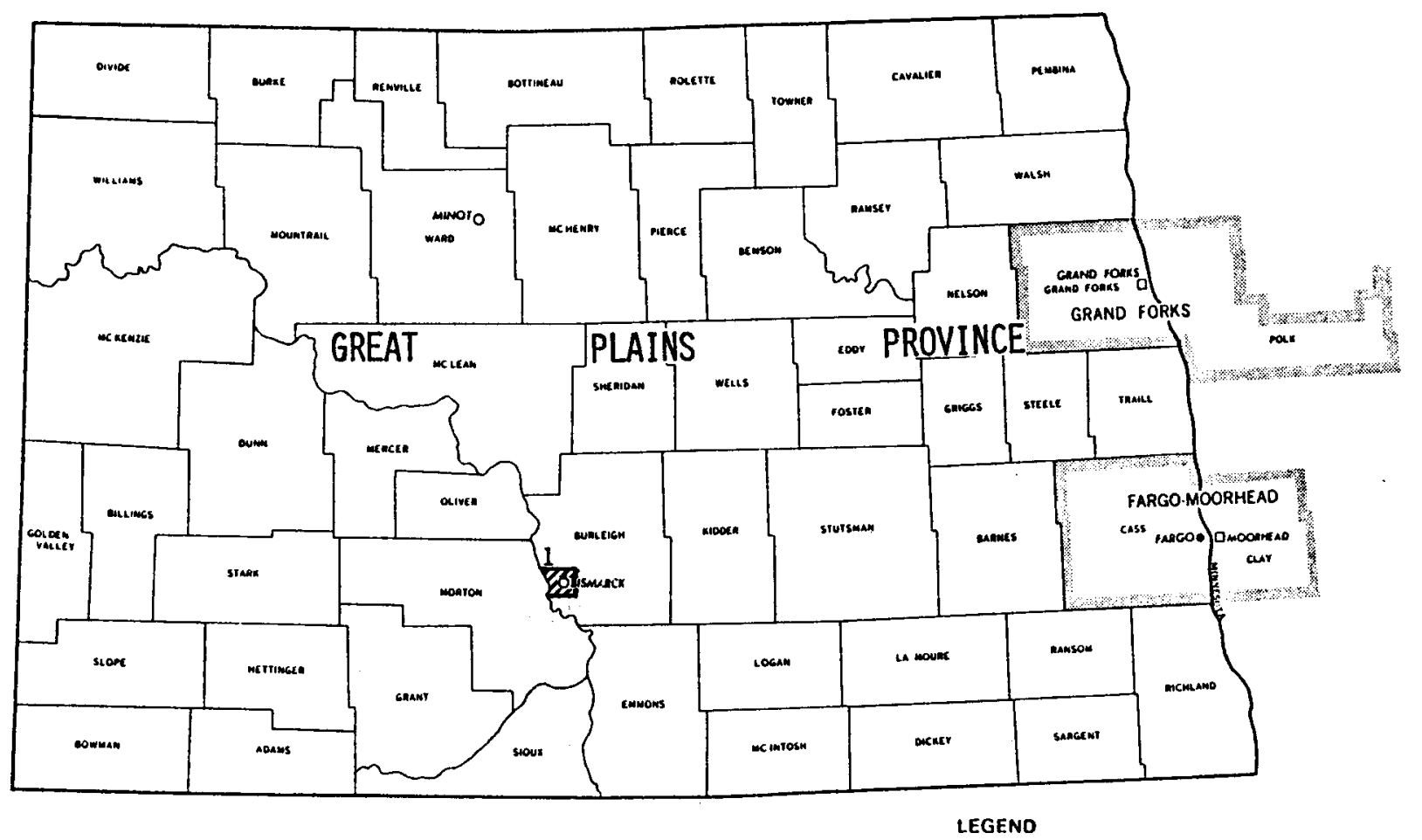

\section{WIA Principal Geothermal Areas}

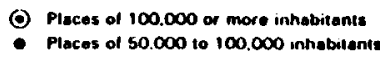

1. Bismarck Direct Heat Project

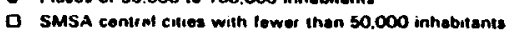

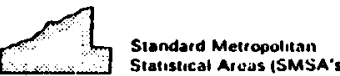

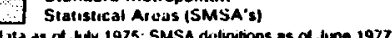

드: $:=0$ 
STATE: NORTH DAKOTA

TABLE 18

ELECTRIC POWER AND DIRECT USE DEVELOPMENT ACTIVITY

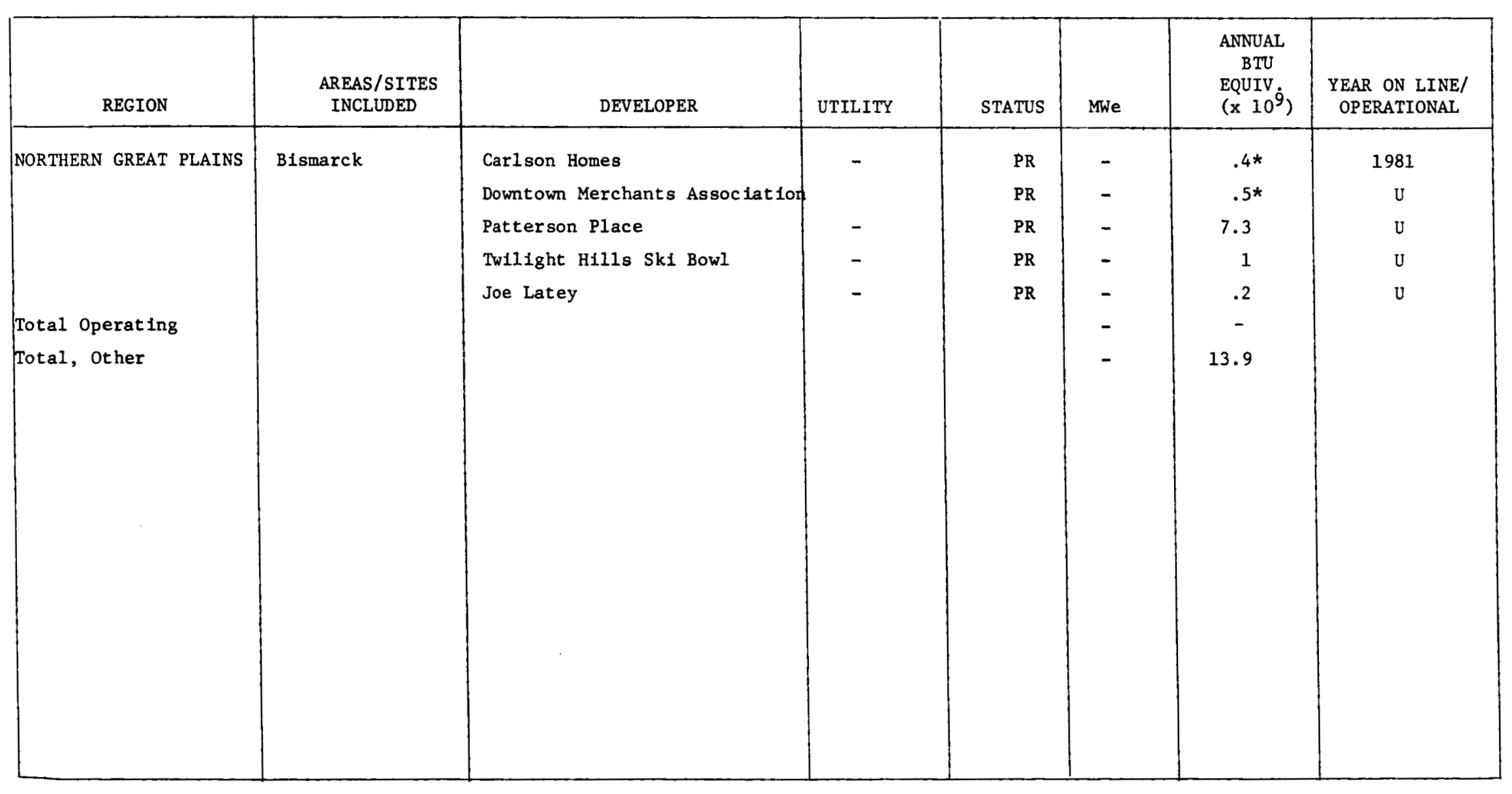

* Annual energy use is a rough estimate.
Code: UC - Under Construction

PR - Proposed

OP - Operating

U - Unknown

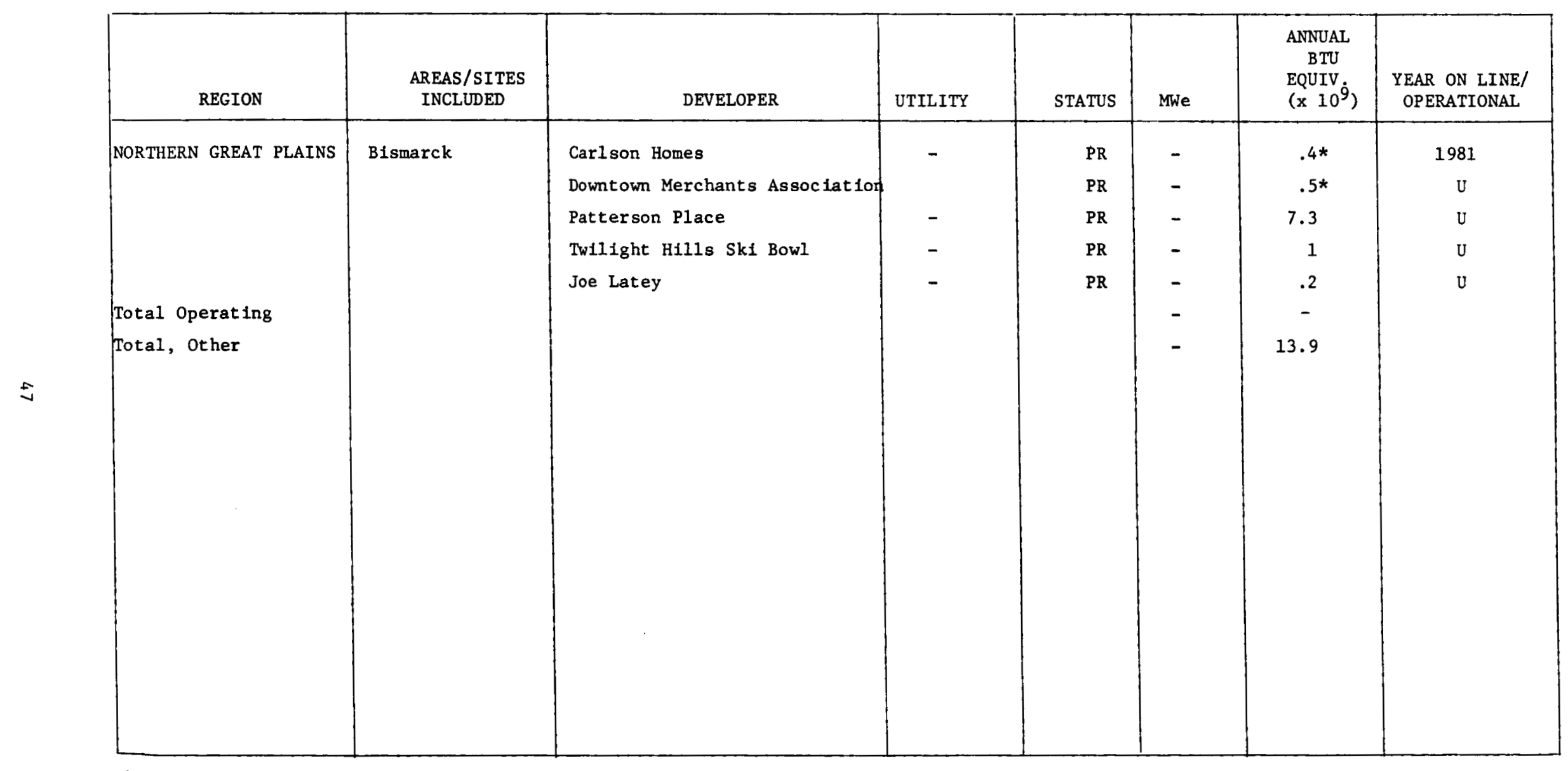




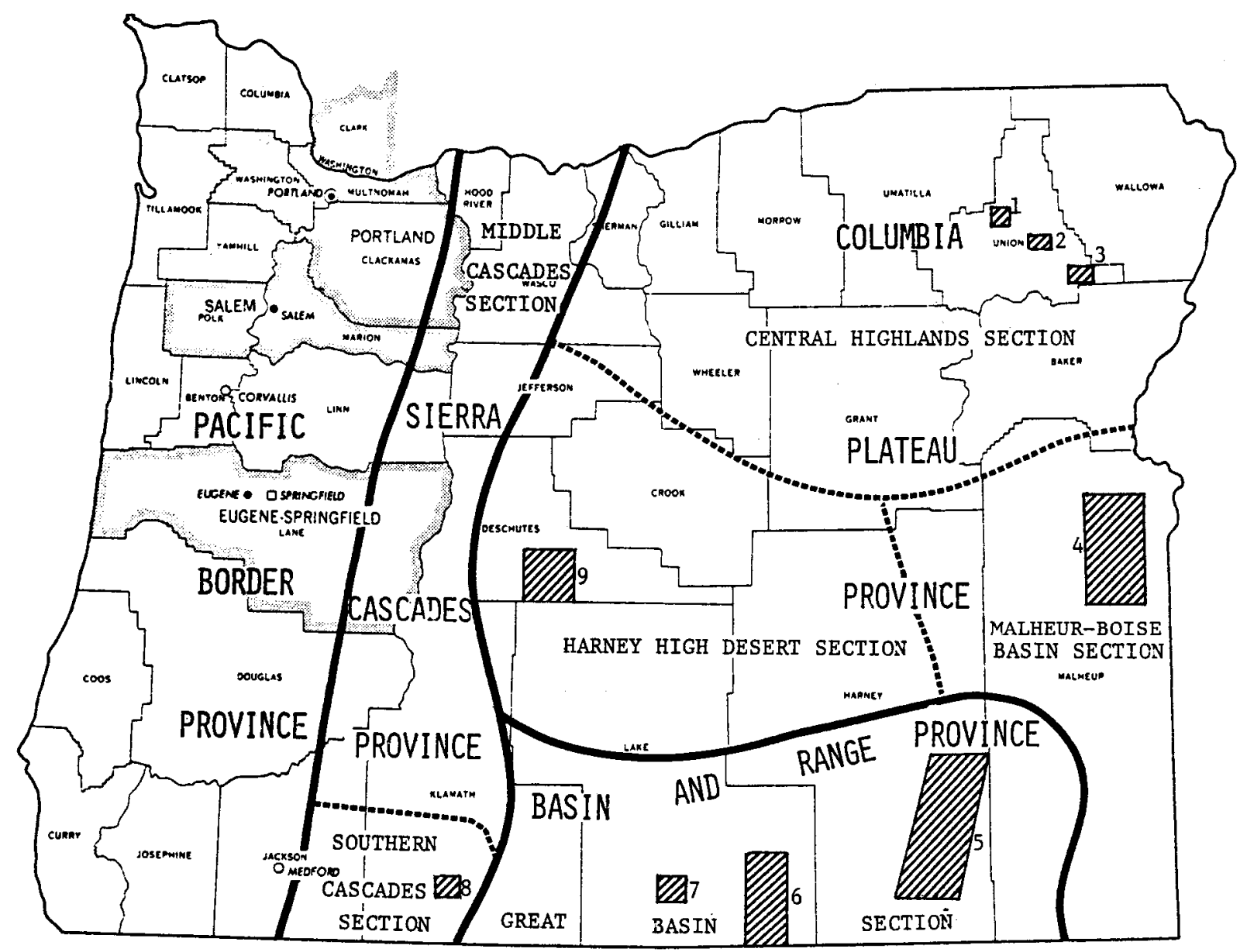

LEGEND

VII Principal Geothermal Areas

1. La Grande Direct Heat Project

2. Hot Lake Direct Heat Project

3. Medical Hot Springs Direct Heat Project

4. Vale Hot Springs KGRA/Adrian Direct Heat Project

5. Alvord Valley KGRA

6. Crump Geyser KGRA

7. Lakeview Direct Heat Project

8. Klamath Falls Direct Heat Project

9. Newberry Caldera
(- Pteces of 100.000 or more inhebitants

- Places of 50.000 to 100.000 inhabitanis

a SMSA central cities with fewer than 50,000 inhabilants

O Places of 25.000 to 50.000 int res:tanis outside SMSA's

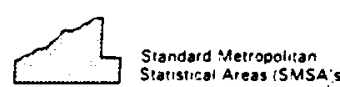

SMSA'S

Pooutation cata as of July 1975 . S: :SA ceftiti:ons as of Jure : 977

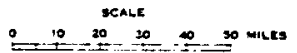

Figure 11

Principal Geothermal Resource Areas in Oregon 
TABLE 19

LANDS LEASED AND/OR EXPLORED

\begin{tabular}{|c|c|c|c|c|c|}
\hline \multirow{2}{*}{ REGION } & \multirow{2}{*}{$\begin{array}{l}\text { AREAS / S ITES } \\
\text { INCLUDED }\end{array}$} & \multirow{2}{*}{$\begin{array}{l}\text { LEASEHOLDER*/ } \\
\text { DEVELOPER }\end{array}$} & \multicolumn{2}{|c|}{ ACREAGE LEASED } & \multirow{2}{*}{$\begin{array}{l}\text { DEEP } \\
\text { WELLS }\end{array}$} \\
\hline & & & Non-Competitive & Competitive & \\
\hline CENTRAL HIGHLANDS & $\begin{array}{l}\text { La Grande } \\
\text { Hot Lake } \\
\text { Medical H.S. }\end{array}$ & & No Active Fede & al Leases & None \\
\hline $\begin{array}{l}\text { HIGH LAVA PLATEAU/ } \\
\text { MALHEUR-BOISE } \\
\text { BASIN }\end{array}$ & $\begin{array}{l}\text { Vale H.S. } \\
\text { Adrian }\end{array}$ & $\begin{array}{l}\text { Amax Exploration } \\
\text { Amax/Earth Power } \\
\text { California Geothermal } \\
\text { Chevron USA } \\
\text { Earth Power } \\
\text { Geothermal Resources } \\
\text { International } \\
\text { Hassie Hunt, Inc. } \\
\text { Republic Geothermal } \\
\text { Rosewood Corporation } \\
\text { Thermal Resources, Inc. } \\
\text { Union Oil } \\
\text { United States Geothermal } \\
\text { Utah International } \\
\text { Private Individuals }\end{array}$ & $\begin{array}{r}16,696 \\
9,434 \\
11,571 \\
5,428 \\
6,674 \\
5,994 \\
5,120 \\
\\
19,700 \\
6,872 \\
560 \\
5,362 \\
2,687 \\
44,930\end{array}$ & $\begin{array}{l}2,560 \\
1,347 \\
8,011\end{array}$ & \\
\hline $\begin{array}{l}\text { HIGH LAVA PLATEAU/ } \\
\text { HARNEY HIGH DESERT }\end{array}$ & Newberry Caldera & $\begin{array}{l}\text { Aminoil USA } \\
\text { California Geothermal } \\
\text { Francana Resources }\end{array}$ & $\begin{array}{r}14,436 \\
32,469 \\
2,635\end{array}$ & & \\
\hline GREAT BASIN & $\begin{array}{l}\text { Alvord Valley KGRA } \\
\text { Crump Geyser KGRA } \\
\text { Lakeview }\end{array}$ & $\begin{array}{l}\text { Al-Aquitaine Exploration } \\
\text { Anadarko Production } \\
\text { California Geothermal } \\
\text { Chevron USA } \\
\text { Delta Funds Inc. } \\
\text { Getty Oil } \\
\text { Hassie Hunt Exploration } \\
\text { Hunt Oil } \\
\text { Placer Amex, Inc. } \\
\text { Supron Energy } \\
\text { Thermal Resources, Inc. } \\
\text { Utah International } \\
\text { Private Individuals }\end{array}$ & $\begin{array}{r}2,541 \\
1,908 \\
3,520 \\
3,193 \\
645 \\
2,492 \\
19,521 \\
4,532 \\
1,680 \\
2,680 \\
40,350\end{array}$ & $\begin{array}{r}7,480 \\
12,223 \\
9,331 \\
11,661 \\
4,715 \\
2,560\end{array}$ & \\
\hline SOUTHERN CASCADES & Klamath Falls & $\begin{array}{l}\text { Hassie Hunt Exploration } \\
\text { Private Individuals }\end{array}$ & $\begin{array}{l}2,770 \\
8,407\end{array}$ & & \\
\hline
\end{tabular}

${ }^{*}$ Federal 1ands only. 
STATE: OREGON

TABLE 20
Code: UC ${ }^{\#}$ - Under Construction

PR - Proposed

OP - Operating

U - Unknown

ELECTRIC POWER AND DIRECT USE DEVELOPMENT ACTIVITY

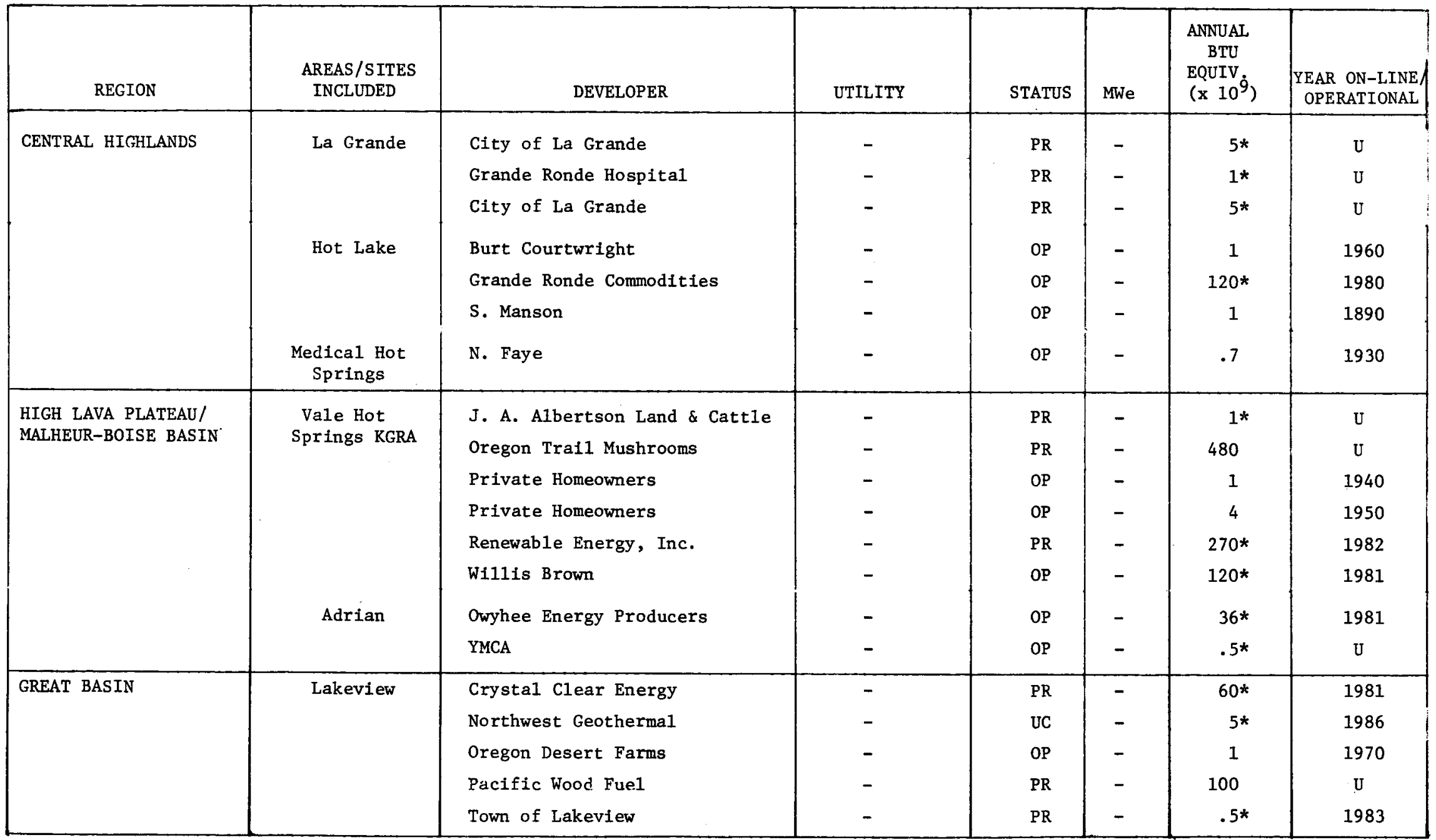

*Annual energy use is a rough estimate.

\#For direct heat projects, construction begins with preliminary development activities such as exploratory drilling. 
STATE: OREGON

TABLE 20 (Continued)

ELECTRIC POWER AND DIRECT USE DEVELOPMENT ACTIVITY

\begin{tabular}{|c|c|c|c|c|c|c|c|}
\hline REGION & $\begin{array}{l}\text { AREAS / S ITES } \\
\text { INCLUDED }\end{array}$ & DEVELOPER & UTILITY & STATUS & MWe & $\begin{array}{l}\text { ANNUAL } \\
\text { BTU } \\
\text { EQUIV } \\
\left(x \quad 10^{9}\right)\end{array}$ & $\begin{array}{l}\text { YEAR ON-LINE/ } \\
\text { OPERATIONAL }\end{array}$ \\
\hline GREAT BASIN & Lakeview & $\begin{array}{l}\text { Unknown } \\
\text { Unknown (District Heating) } \\
\text { Unknown }\end{array}$ & $\begin{array}{l}- \\
-\end{array}$ & $\begin{array}{l}\text { OP } \\
P R \\
P R\end{array}$ & $\begin{array}{l}- \\
-\end{array}$ & $\begin{array}{r}100 * \\
5 * \\
5 *\end{array}$ & $\begin{array}{l}\mathrm{U} \\
\mathrm{U} \\
\mathrm{U}\end{array}$ \\
\hline SOUTHERN CASCADES & Klamath Falls & $\begin{array}{l}\text { Apartment Complex } \\
\text { City of Klamath Falls } \\
\text { City of Klamath Falls } \\
\text { Diverse Coimmunity Businesses } \\
\text { Fairview Elementary School } \\
\text { High Valley Services, Inc. } \\
\text { Homeowners } \\
\text { Indian Rock Greenhouses } \\
\text { Keenan Smith } \\
\text { Kingwood Apartments } \\
\text { Klamath County } \\
\text { Klamath County YMCA } \\
\text { Klamath Falls School } \\
\text { District } \\
\text { Klamath Lutheran Church } \\
\text { Liskey Farms } \\
\text { Medo-Bel Creamery } \\
\text { Merle West Medical Center } \\
\text { Modoc Lumber Company } \\
\text { Mountain View Professional } \\
\text { Building } \\
\text { Oregon Department of Higher } \\
\text { Education }\end{array}$ & $\begin{array}{l}- \\
- \\
- \\
- \\
- \\
- \\
- \\
- \\
- \\
- \\
- \\
- \\
- \\
- \\
- \\
- \\
- \\
- \\
-\end{array}$ & $\begin{array}{l}P R \\
U C \\
P R \\
O P \\
P R \\
P R \\
O P \\
O P \\
O P \\
O P \\
O P \\
O P \\
O P \\
O P \\
O P \\
O P \\
O P \\
P R \\
O P \\
O P\end{array}$ & $\begin{array}{l}- \\
- \\
- \\
- \\
- \\
- \\
- \\
- \\
- \\
- \\
- \\
- \\
-\end{array}$ & $\begin{array}{c}2 * \\
35 \\
25 \\
.7 \\
.5 * \\
1 * \\
14 \\
5 * \\
2 \\
6 \\
1 * \\
5 \\
9 \\
1 * \\
2 \\
100 * \\
.5 \\
100 * \\
1 * \\
7\end{array}$ & $\begin{array}{c}U \\
1981 \\
U \\
1945 \\
U \\
U \\
1900 \\
1980 \\
1979 \\
1960 \\
U \\
1980 \\
1974 \\
U \\
1978 \\
U \\
1974 \\
U \\
1981 \\
1963\end{array}$ \\
\hline
\end{tabular}


STATE: OREGON

TABLE 20 (Concluded)

ELECTRIC POWER AND DIRECT USE DEVELOPMENT ACTIVITY

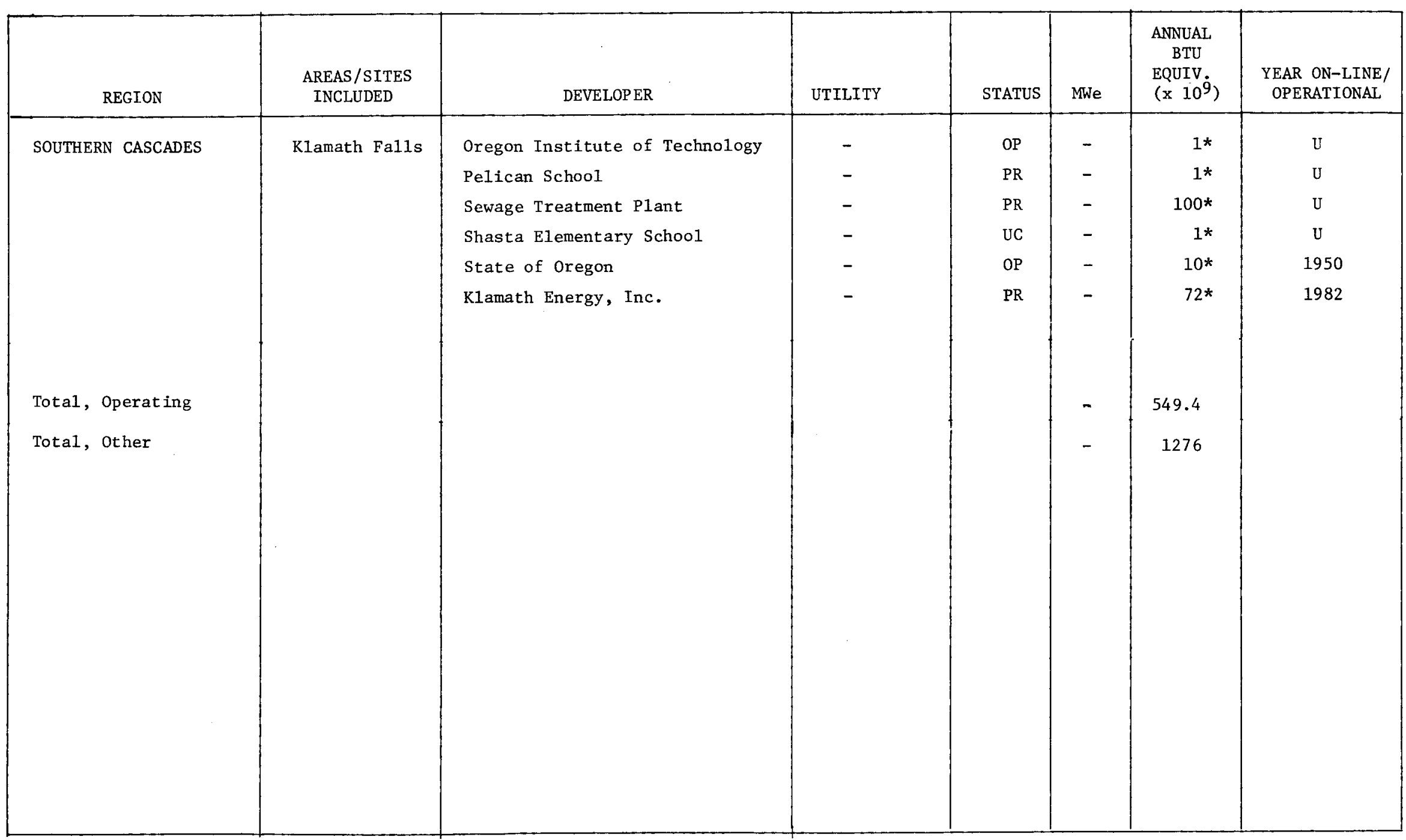




\section{Direct Heat Applications}

Geothermal direct heat is being used primarily for residential and commercial space heating in South Dakota. In the city of Philip, four projects are in operation, which include heating of five school buildings and a manufacturing plant and providing industrial process heat to a water treatment facility. Public school buildings in Midland are also being heated geothermally. St. Mary's Hospital in Pierre has used geothermal energy for space heating since last year. Proposed uses in Pierre include heating of the Capitol Ma11, greenhouse heating, and a project to heat 200 residences. Finally, the town of Lemmon is proposing a multiple-use project which would include district heating, ethanol production, grafn drying, and greenhouse heating, with estimated annual use of over one trillion Btus. Projects are summarized in Table 22.

TEXAS

Though Texas has extensive geopressured geothermal resources from which methane recovery may be feasible in the next few years, geothermal development there is currently limited to direct heat applications of low-temperature geothermal waters.

Leasing and Exploration

A total of three deep producible wells have been completed at the principal geothermal areas in Texas (Figure 13, Table 23). There are no active federal leases in the identified resource areas.

\section{Direct Heat Applications}

Five geothermal space and district heating projects are proposed or under construction. Space heating systems for Torbett-Hutchins-Smith Memorial Hospital in Martin and Navarro College and Hospital in Corsicana are currently under development. These projects are summarized in Table 24.

UTAH

Utah contains primarily moderate-temperature resources suitable for direct heat applications, although there is a high-temperature resource in the Roosevelt Hot Springs KGRA in the southern part of the state. Utah is beginning to look at ways of developing this resource potential and has recently passed new legislation to help enhance beneficial use of geothermal resources in the state.

\section{Leasing and Exploration}

The principal geothermal resource areas in the state of Utah are identified in Figure 14 . Two deep producible wells have been completed in the state (Table 25).

The greatest amount of land under competitive lease is held by Phillips Petroleum in the Roosevelt Hot Springs area. Other major competitive leaseholders are Amax, Union, Mother Earth Industries, and Aminoll USA. The principal leaseholders overall are Atlantic Richfield, Phillips, and Chevron USA. Most of the leases are in the Great Basin region, which includes Roosevelt Hot Springs, site of a proposed 50 MWe power plant.

\section{Direct Heat Applications}

Most of the direct heat projects in Utah are in the Crystal Hot Springs area, where geothermal direct heat is being used for tropical fish raising and heating of two greenhouses. A project to heat the Utah Prison is currently under construction and a space heating project for a convalescent facility has been proposed. A geothermally-heated spa is in operation in the Sevier area, where a residential district heating project is also under construction by Monroe City. In the Cove FortSulphurdale KGRA, R\&R Energies is buflding a 7 million gallon-a-year geothermal ethanol plant.

\section{Electric Power Development}

In the Roosevelt Hot Springs KGRA near Milford in Beaver County, the Utah Power and Light Company, in conjunction with Philips Petroleum, is planning to build three geothermal electric power plants. A 20 MWe unit is expected to come on 1ine in 1984. Two 50 MWe units will follow.

Roosevelt Hot Springs is also the site of an upcoming DOE/EPRI field test of a new rotary separator turbine. 


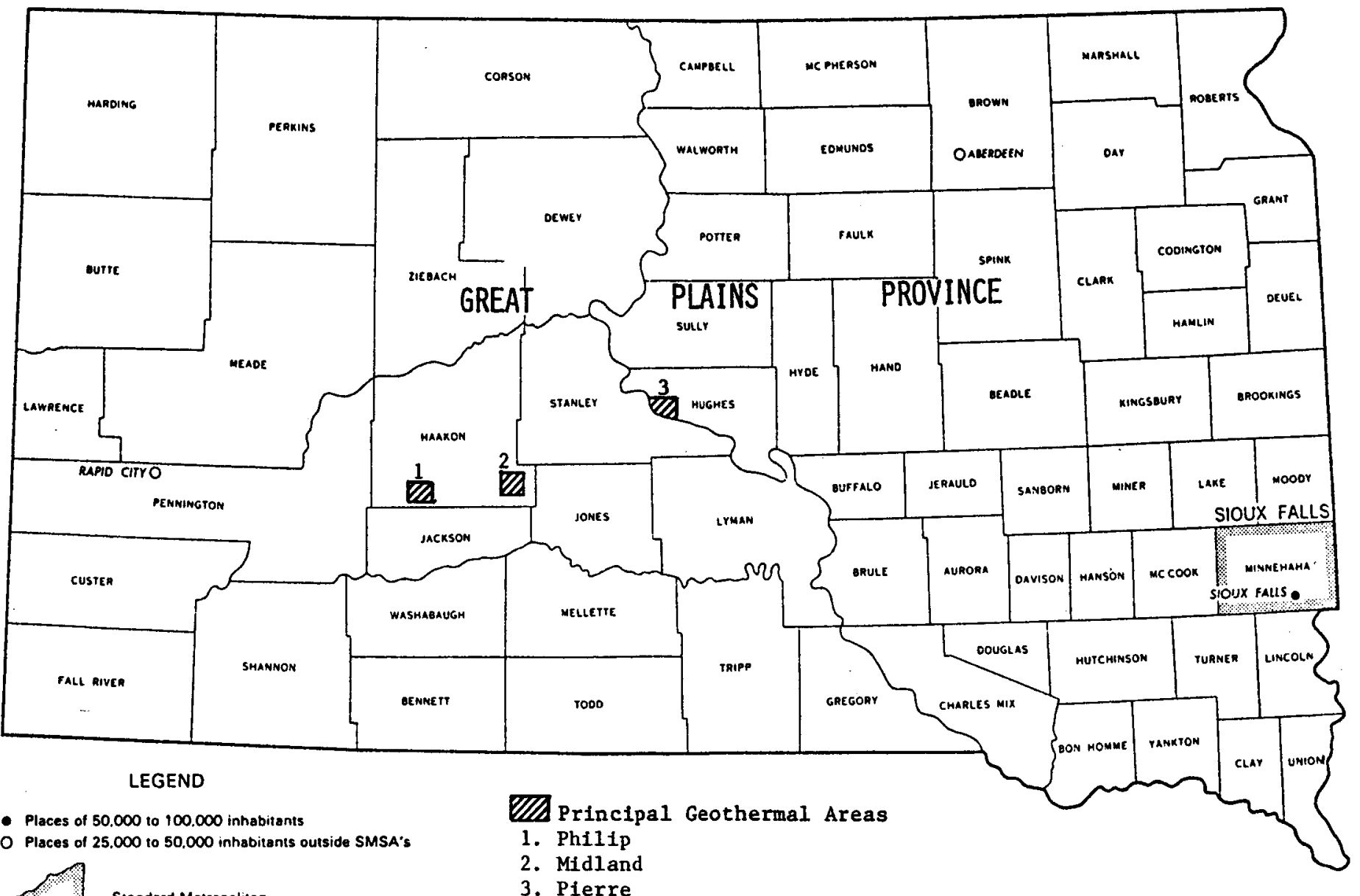

Standard Metropolitan
Statistical Areas ISMSA's

3. Pierre

Population data as of July 1975: SMSA detinitions as of June 1977

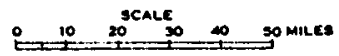


TABLE 21

LANDS LEASED AND/OR EXPLORED

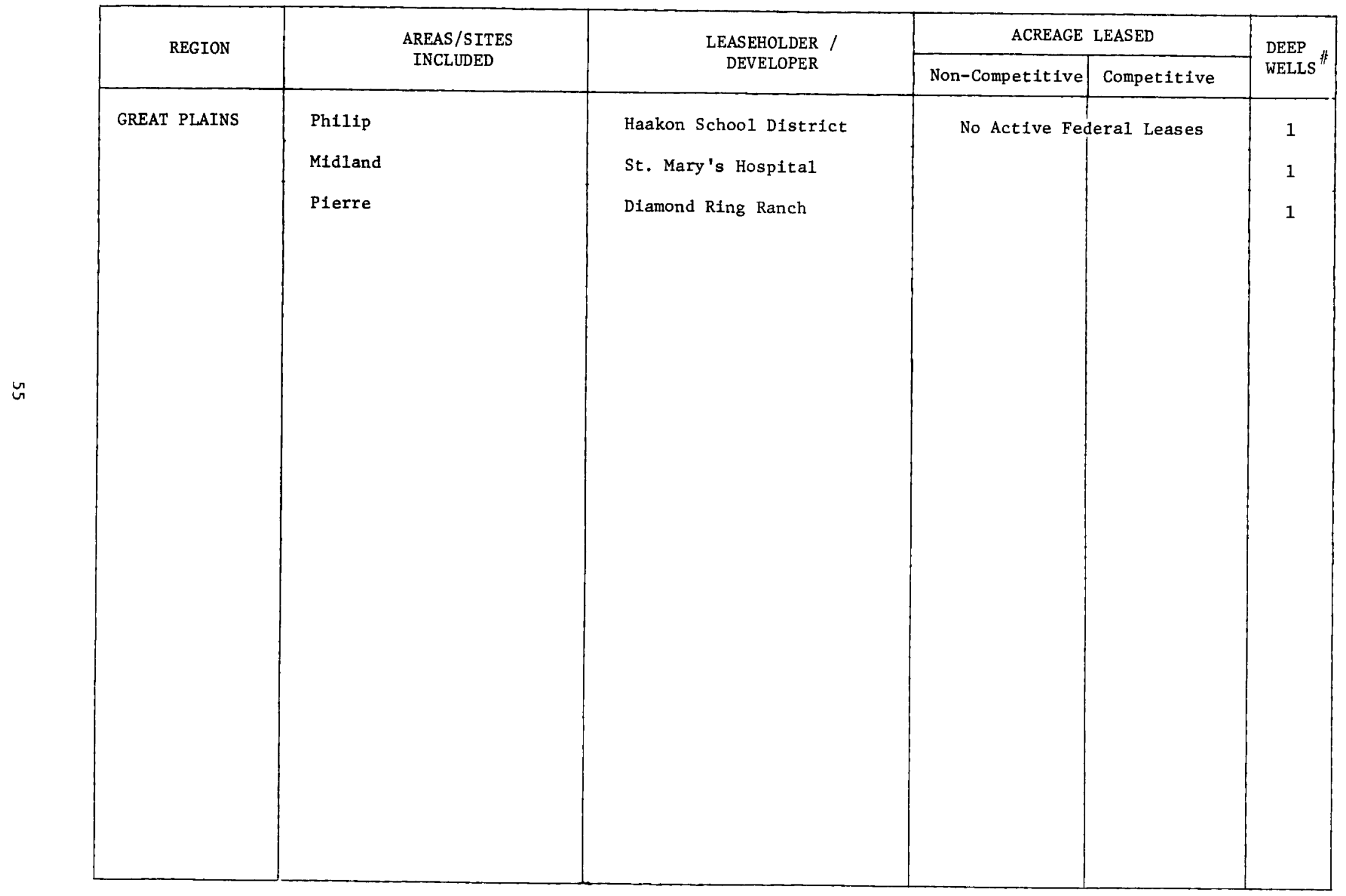

\#Wells over 2000 feet known to be producible. 
STATE: SOUTH DAKOTA

TABLE 2

ELECTRIC POWER AND DIRECT USE AND DEVELOPMENT ACTIVITY
Code: UC - Under Construction

PR - Proposed

OP - Operating

$\mathrm{U}$ - Unknown

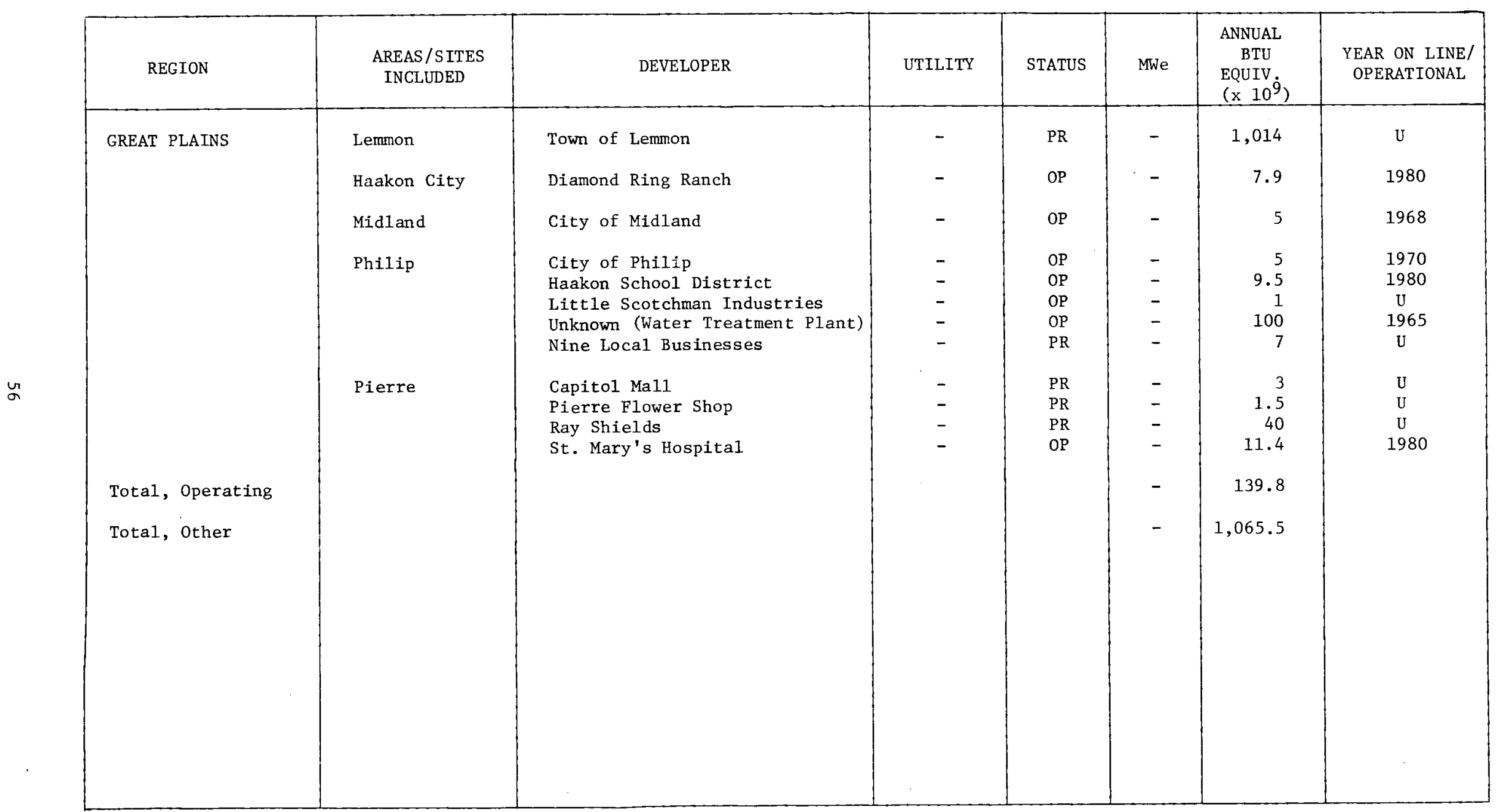




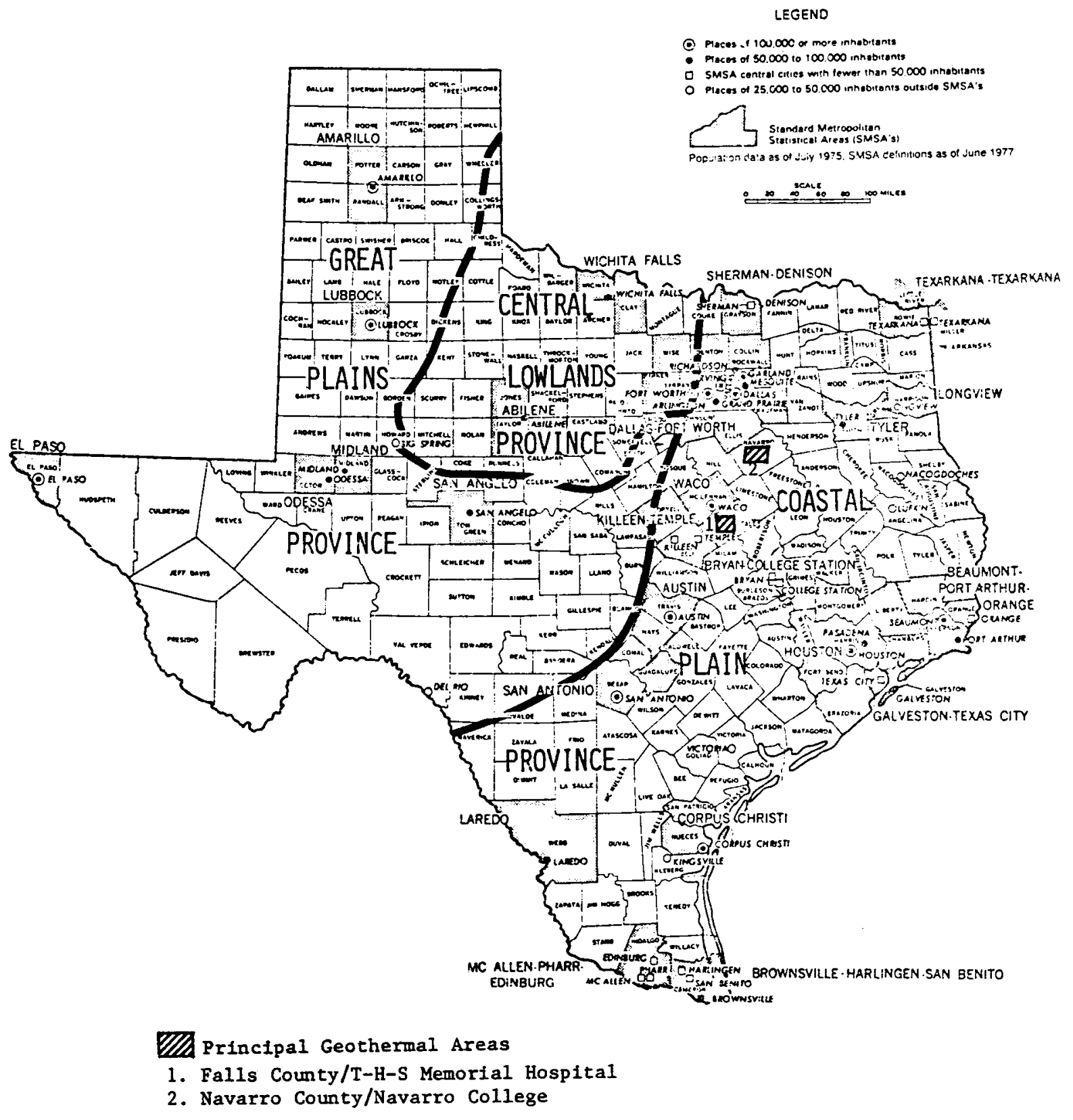

Figure 13

Principal Geothermal Resource Areas in Texas 
STATE: TEXAS

TABLE 23

LANDS LEASED AND/OR EXPLORED

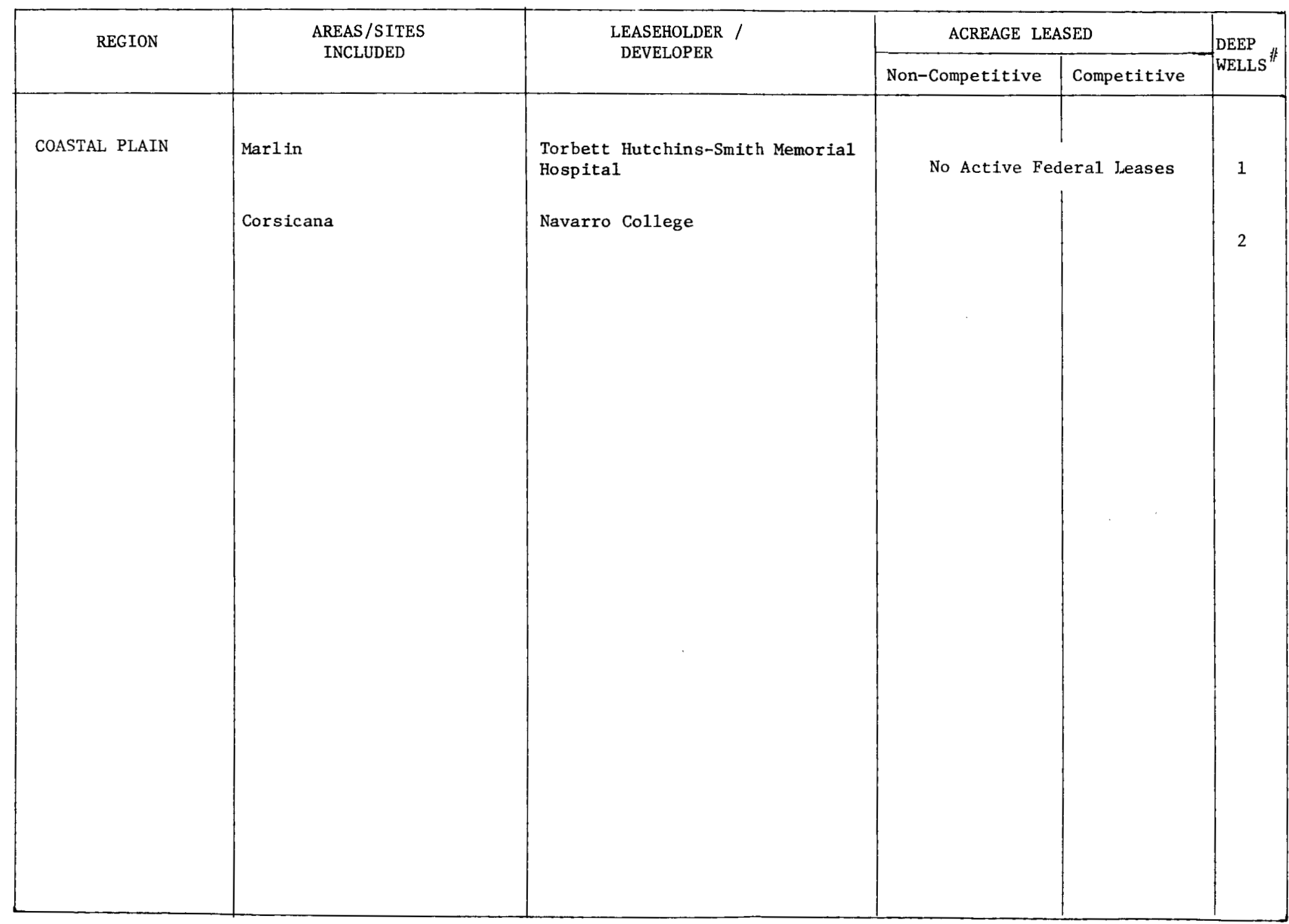

\#Wells over 2000 feet known to be producible. 
STATE :

TEXAS

TABLE 24

ELECTRIC POWER AND DIRECT USE DEVELOPMENT ACTIVITY

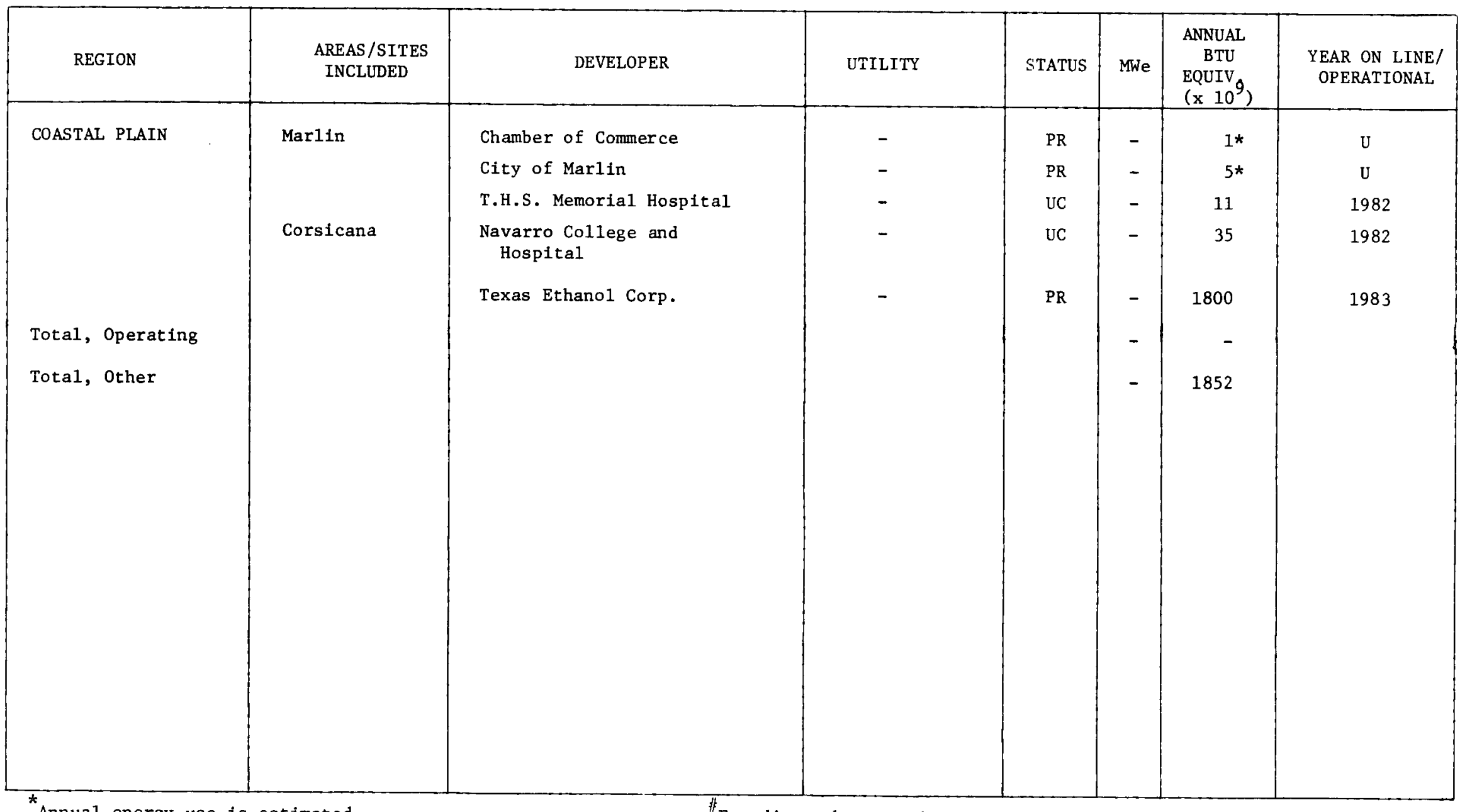

Annual energy use is estimated.
Code: $U^{\#} C^{\#}$ - Under Construction

PR - Proposed

OP - Operating

$\mathrm{U}$ - Unknown 
Electric power and direct heat projects are summarized in Table 26.

Recent Major Activities

- Geothermal Bill Passed

A bill establishing procedures and regulation guidelines for development of Utah's geothermal energy has been passed by the state leglslature. The Geothermal Conservation Act grants authority over geothermal resources to the Division of Water Rights, defines the resource, and includes provisions for the protection of correlative rights, prevention of waste, and authorization and procedures for using geothermal areas. Under the Utah law, geothermal energy is defined as temperatures in the earth above $120^{\circ} \mathrm{C}\left(245^{\circ} \mathrm{F}\right)$.

Source: GRC Bulletin, Feb./Mar. 1981, Jan. 1981.

\section{- Hunt 011 Takes Leases in State Sale}

Hunt oil was the sole bidder at a geothermal lease sale held March 30, 1981 by the Utah Department of Natural Resources. The company took all the acreage up for bid -- approximately 1919 acres in Beaver and Millard countles -- and paid a total bonus of $\$ 6715.35$. The Beaver County leases are within 18 miles southwest of the Roosevelt Hot Springs KGRA; the Millard County leases are some 25 miles north of that KGRA.

$$
\text { Source: PIC NGS, 4/3/81. }
$$

WASHINGTON

Some low- to moderate-temperature resources are known in Washington. These resources are being used for direct heat applications in some areas. The state has begun to investigate ways of enhancing $i$ ts geothermal resource potentia1. Washington contains extensive National Forest Service lands, many of which are expected to be leased in the next year.

\section{Leasing and Exploration}

Most of the principal geothermal areas in the state of Washington are situated in the Cascade Mountain Range. Figure 15 is an Index map of the principal locations.

No productble deep wells have been completed in the areas identified as having geothermal resource potential. Leaseholders are shown in Table 27.

\section{Direct Heat Applications}

The City of North Bonneville has started drilling for a commercial district heating project and is considering expanding the project to light industry process heating applications. The City of Ephrata has proposed use of geothermally-assisted heat pumps to heat 12 public housing units and a courthouse. These projects are summarized in Table 28.

Recent Major Activities

\section{- Washington Bill Establishes Geothermal Revenue Fund}

Washington state legislators have passed a bill requiring that revenue received from geothermal leases on federal lands be deposited into a state geothermal fund.

When U.S. Forest Service (USFS) or Bureau of Land Management (BLM) admin1stered lands are leased for geothermal exploration and development, 50 percent of the lease fee is made available to the state. The newly passed legislation in the state of Washington provides that these funds be appropriated to the counties of origin to mitigate the social, economic and environmental impacts of geothermal development; to the Department of Natural Resources and Division of Geology and Earth Resources for continuing geothermal resource assessment; and to the Washington State Energy office for expansion of 1 ts geothermal commercialization and development program. The legislation is similar to California's AB 1905, signed into law on May 30, 1980.

The J.S. Forest Service estimates that 148 lease applications in the state of Washington will receive final action during 1981. These initial leases, totaling approximately 350,000 acres, could result in $\$ 150,000$ to $\$ 175,000$ being made avallable for deposit into the state geothermal fund annually for five to ten years. The leasing of additional acreage will increase this amount, as will royalties that will become available after development of the geothermal leases. 


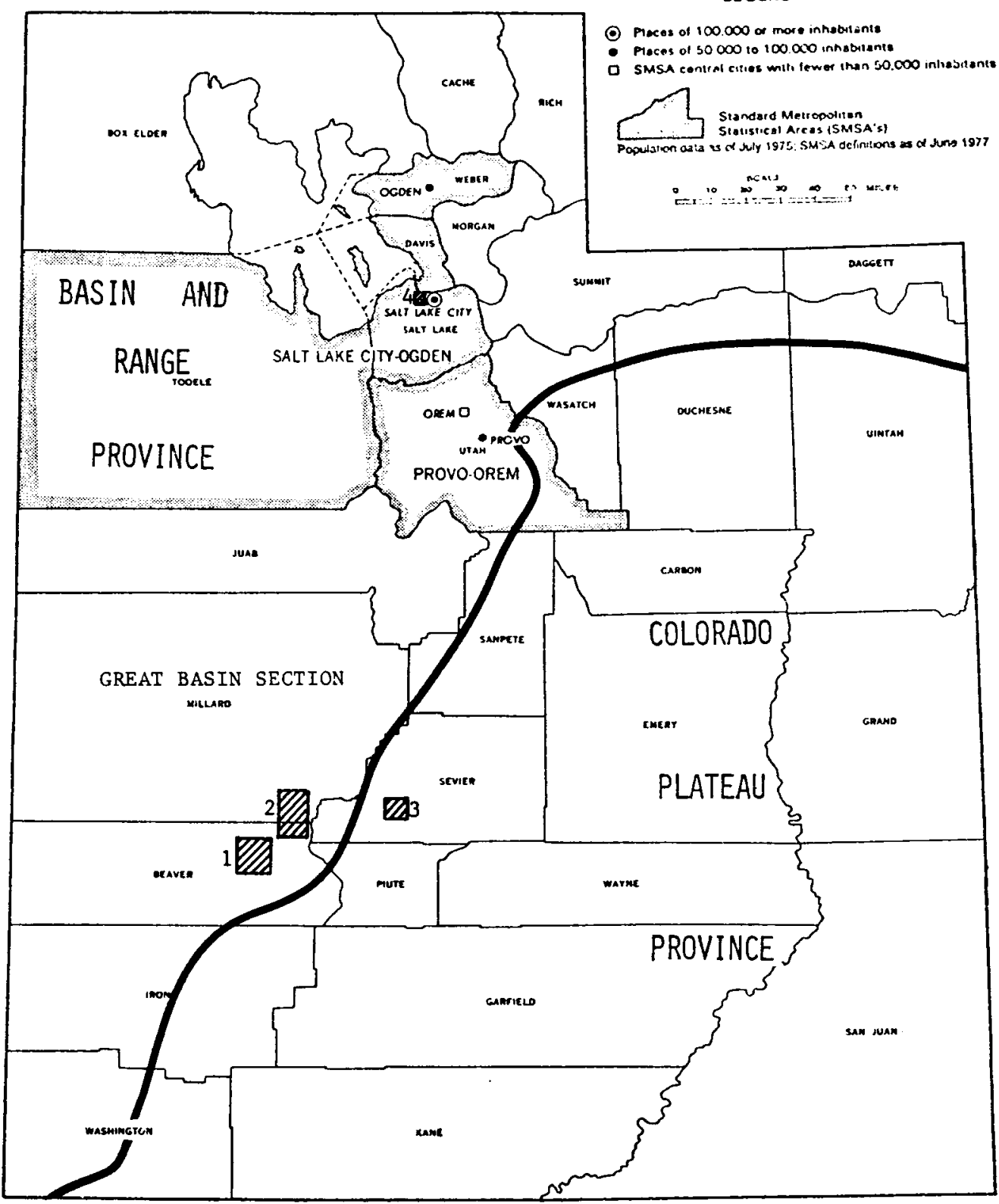

Princlpal Geothermal Areas

1. Roosevelt Hot Springs KGRA

2. Cove Fort-Sulphurdale KGRA

3. Sevier Direct Heat Project

4. Crystal Springs

Figure 14

Principal Geothermal Resource Areas in Utah 
TABLE 25

LANDS LEASED AND/OR EXPLORED

\begin{tabular}{|c|c|c|c|c|c|}
\hline \multirow{2}{*}{ REGION } & \multirow{2}{*}{$\begin{array}{l}\text { AREAS/SITES } \\
\text { INCLUDED }\end{array}$} & \multirow{2}{*}{$\begin{array}{l}\text { LEASEHOLDER* / } \\
\text { DEVELOPER }\end{array}$} & \multicolumn{2}{|c|}{ ACREAGE LEASED } & \multirow{2}{*}{$\begin{array}{l}\text { DEEP } \\
\text { WELLS }\end{array}$} \\
\hline & & & Non-Competitive & Competitive & \\
\hline GREAT BASIN & $\begin{array}{l}\text { Rooseve1t H.S. } \\
\text { Cove Fort/Sulphurdale } \\
\text { Crystal Springs } \\
\end{array}$ & $\begin{array}{l}\text { Amax Exploration } \\
\text { American Geological } \\
\text { Enterprises } \\
\text { Amoco Production Co. } \\
\text { Atlantic Richfield } \\
\text { Bow Valley Coal } \\
\text { Resources } \\
\text { Chevron USA } \\
\text { Earth Power Corp. } \\
\text { Geothermal Explora- } \\
\text { ation, Inc. } \\
\text { Geothermal Power Corp. } \\
\text { Getty Oil } \\
\text { Mother Earth Industries, } \\
\text { Inc. } \\
\text { Mountain States } \\
\text { Resources Corp. } \\
\text { O'Brien Resources } \\
\text { Phillips Petroleum } \\
\text { Plattsburgh Quarries, } \\
\text { Inc. } \\
\text { Stewart Capital Corp. } \\
\text { Thermal Power of Utah } \\
\text { Thermal Resources, Inc. } \\
\text { Thermogenics, Inc. } \\
\text { Union Oil of Calif. } \\
\text { United States Geothermal } \\
\text { Private Individuals } \\
\text { Utah Roses }\end{array}$ & $\begin{array}{r}2,660 \\
1,923 \\
20,383 \\
3,840 \\
\\
9,629 \\
2,560 \\
5,737 \\
\\
640 \\
\\
\\
1,946 \\
7,821 \\
11,863 \\
\\
2,520 \\
8,140 \\
2,109 \\
6,220 \\
8,933 \\
87,666\end{array}$ & $\begin{array}{r}1,920 \\
8,746 \\
r, 840 \\
40 \\
\\
2,560 \\
2,920\end{array}$ & 1 \\
\hline $\begin{array}{l}\text { WESTERN HIGH } \\
\text { PLATEAUS }\end{array}$ & Sevier & $\begin{array}{l}\text { Aminoil USA } \\
\text { Roosevelt H.S. Corp. } \\
\text { Thermex } \\
\text { Union Oil of Calif. } \\
\text { Private Individuals }\end{array}$ & $\begin{array}{r}2,840 \\
707 \\
960 \\
1,920\end{array}$ & $\begin{array}{l}4,066 \\
2,572\end{array}$ & \\
\hline
\end{tabular}

${ }^{\star}$ Federa1 lands on1y.

非 11 s over 2000 feet known to be producible. 
STATE: UTAH

TABLE 26
Code: UC ${ }^{\#}$ - Under Construction

PR - Proposed

OP - Operating

$\mathrm{U}$ - Unknown

ELECTRIC POWER AND DIRECT USE DEVELOPMENT ACTIVITY

\begin{tabular}{|c|c|c|c|c|c|c|c|}
\hline REGION & $\begin{array}{l}\text { AREAS/SITES } \\
\text { INCLUDED }\end{array}$ & DEVELOPER & UTILITY & STATUS & MWe & $\begin{array}{c}\text { ANNUAL } \\
\text { BTU } \\
\text { EQUIV } \\
\left(\begin{array}{ll}\times & 10^{9}\end{array}\right)\end{array}$ & $\begin{array}{l}\text { YEAR ON-LINE/ } \\
\text { OPERATIONAL }\end{array}$ \\
\hline \multirow[t]{9}{*}{ GREAT BASIN } & \multirow[t]{3}{*}{$\begin{array}{r}\text { Roos eve1t Hot } \\
\text { Springs KGRA }\end{array}$} & Phillips Petroleum & $\begin{array}{l}\text { Utah Power } \\
\& \text { Light Co. }\end{array}$ & $\mathrm{PR}$ & 20 & & 1984 \\
\hline & & Phillips Petroleum & $\begin{array}{l}\text { Utah Power } \\
\& \text { Light Co. }\end{array}$ & PR & 50 & & $\mathrm{U}$ \\
\hline & & Phillips Petroleum & $\begin{array}{l}\text { Utah Power } \\
\text { \& Light Co. }\end{array}$ & PR & 50 & & $\mathrm{U}$ \\
\hline & $\begin{array}{l}\text { Cove Fort - } \\
\text { Sulphurdale KGRA }\end{array}$ & R\&R Energies & - & UC & - & $420 *$ & 1981 \\
\hline & \multirow{5}{*}{$\begin{array}{l}\text { Crystal Hot } \\
\text { Spings }\end{array}$} & G. $\operatorname{Cox}$ & - & PR & - & 1 & $\mathrm{U}$ \\
\hline & & Unknown & - & OP & - & $5 *$ & $\mathrm{U}$ \\
\hline & & Unknown & - & OP & - & $.5 *$ & U \\
\hline & & Utah Róses & - & $\mathrm{OP}$ & - & $16 *$ & 1980 \\
\hline & & Utah State Prison & - & $\mathrm{UC}$ & - & 18 & 1982 \\
\hline $\begin{array}{l}\text { WESTERN HIGH } \\
\text { PLATEAUS }\end{array}$ & Sevier & Karl Meacham & - & $\mathrm{OP}$ & - & 9 & U \\
\hline & & Monroe City & - & $\mathrm{UC}$ & & $5 *$ & 1981 \\
\hline Total, Operating & & & & & - & 30.5 & \\
\hline Total, Other & & & & & 120 & 444 & \\
\hline
\end{tabular}

*Annual energy use is estimated. 


\section{OIIA Principal Geothermal Areas}

\section{Bellingham}

2. Mt. Baker, Southeast

3. Edward Springs

4. Kennedy Hot Springs KGRA

5. Mt.. Rainier, South

6. Yakima, Northwest

7. Cispus River

8. North Fork Tootle River

9. Mt. St. Helens, East

10. Mt. Adams, South

11. City of Vancouver

12. North Bonneville

13. City of Ephrata
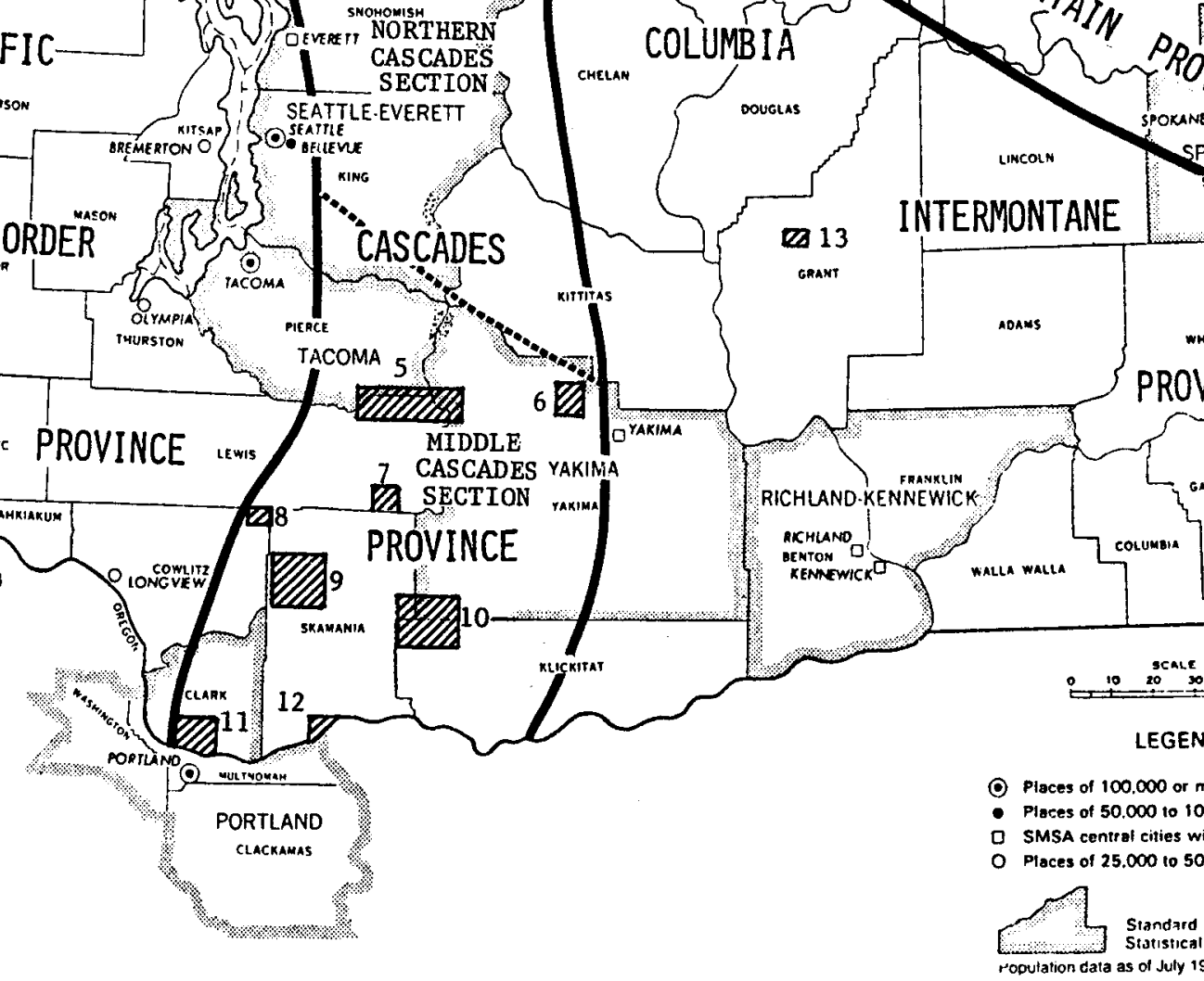

COLUMBIA
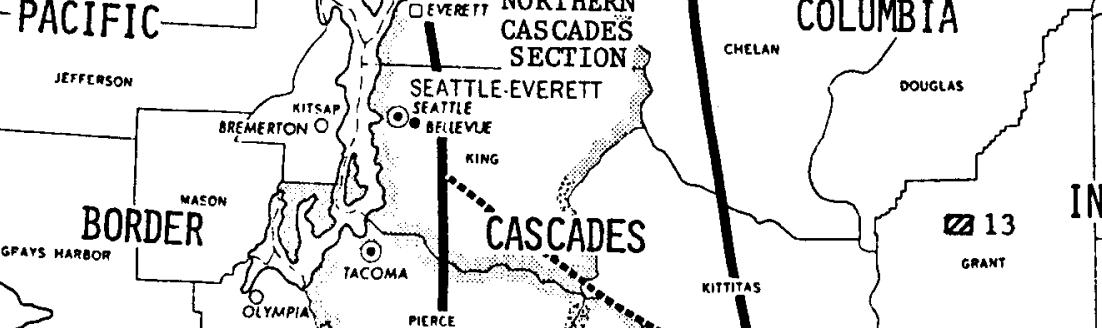

uncoin

const

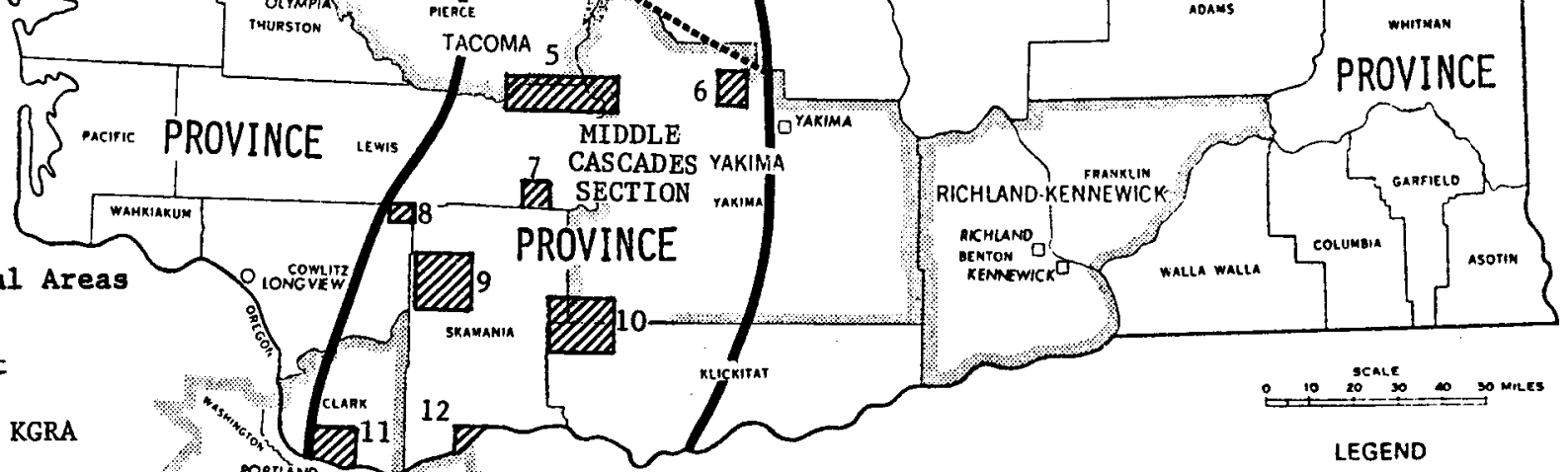

- Places of 50.000 to 100.000 inhabots onts

Pleces of 25.000 io 50.000 inhabitants ourside SMSA's 
STATE:_WASHINGTON

TABLE 27

LANDS LEASED AND/OR EXPLORED

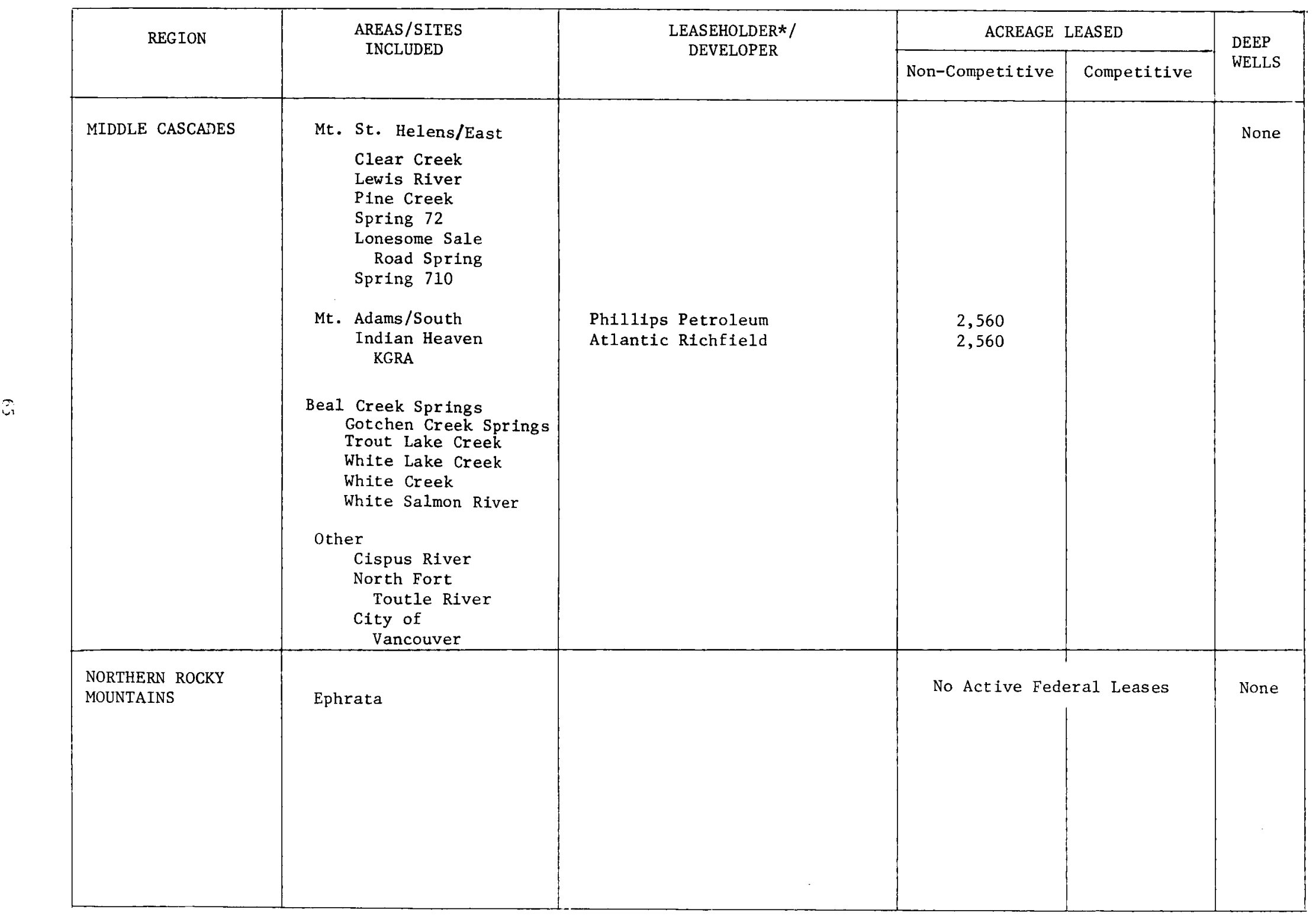

* Federal lands only. 
Code: UC\# - Under Construction

PR - Proposed

OP - Operating

U - Unknown

ELECTRIC POWER AND DIRECT USE DEVELOPMENT ACTIVITY

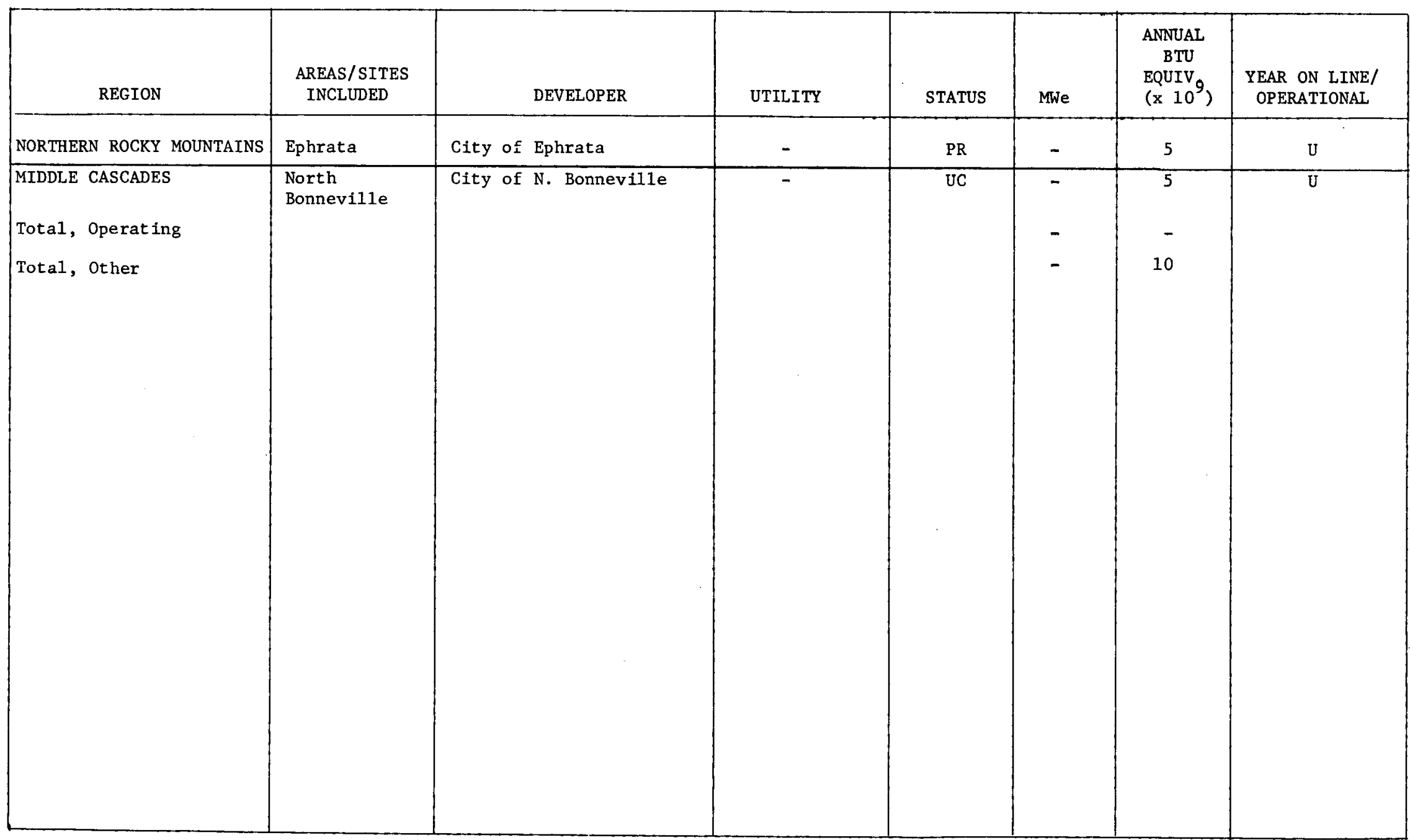

\#Fr direct heat projects, construction begins with preliminary development activities such as exploratory drilling. 
WYOMING

Wyoming contains no apparent high-temperature resources. Geothermal fluids are used for a few direct heat projects and by the enhanced ofl recovery Industry for water-flooding. The Wyoming state leglslature has recently passed two bills which should encourage development of the state's geothermal resources.

\section{Leasing and Exploration}

The principal geothermal resource areas Identified in the state of Wyoming are shown in Figure 16. There has been no leasing activity in these areas and no deep, productble wells have been completed.

Direct Heat Applications

Two geothermal direct use projects are currently in operation. One is an irrigation project at Midwest; the other is at Salt Creek, where Amoco has used geothermal water flooding for enhanced oil recovery since 1964 .

A private developer at Salt Creek has proposed use of geothermal energy for ofl field operatlons and an ethanol plant. Other proposed projects include a multiple-use aquacultural, greenhoustng, and district heating project at an Industrial park in Midwest and district heating in the city of Thermopolis. A greenhouse heating system is under construction. These projects are summarized in Table 29.

\section{Recent Major Activities}

\section{- State Leg1slature Passes Geothermal Bills}

Two geothermal-related bills have been passed by the Wyoming state legislature. One of these bills (H.B. 282) authorizes leasing of state or school lands; the other (H.B. 283) amends Wyoning water law, specifying heat extraction as a "beneficial" use of water and defining geothermal resources as ground water. As such, their exploration, development, and use falls under the regulatory authority of the State Engineer.

Source: GRC Bulletin, 4/81. 


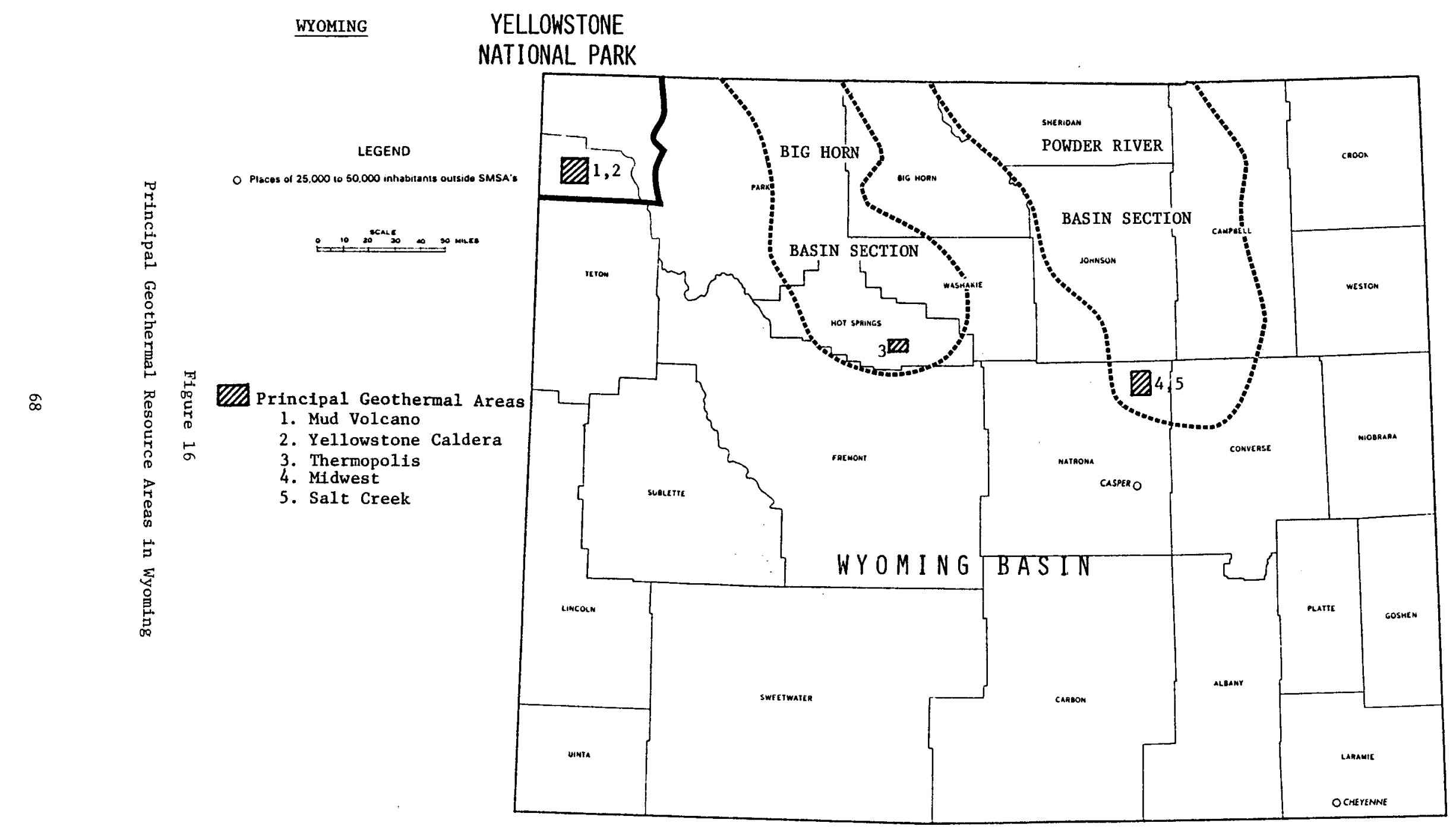


STATE: WYOMING

TABLE 29

ELECTRIC POWER AND DIRECT USE DEVELOPMENT ACTIVITY
Code: UC

PR - Proposed

OP - Operatin

U - Unknown

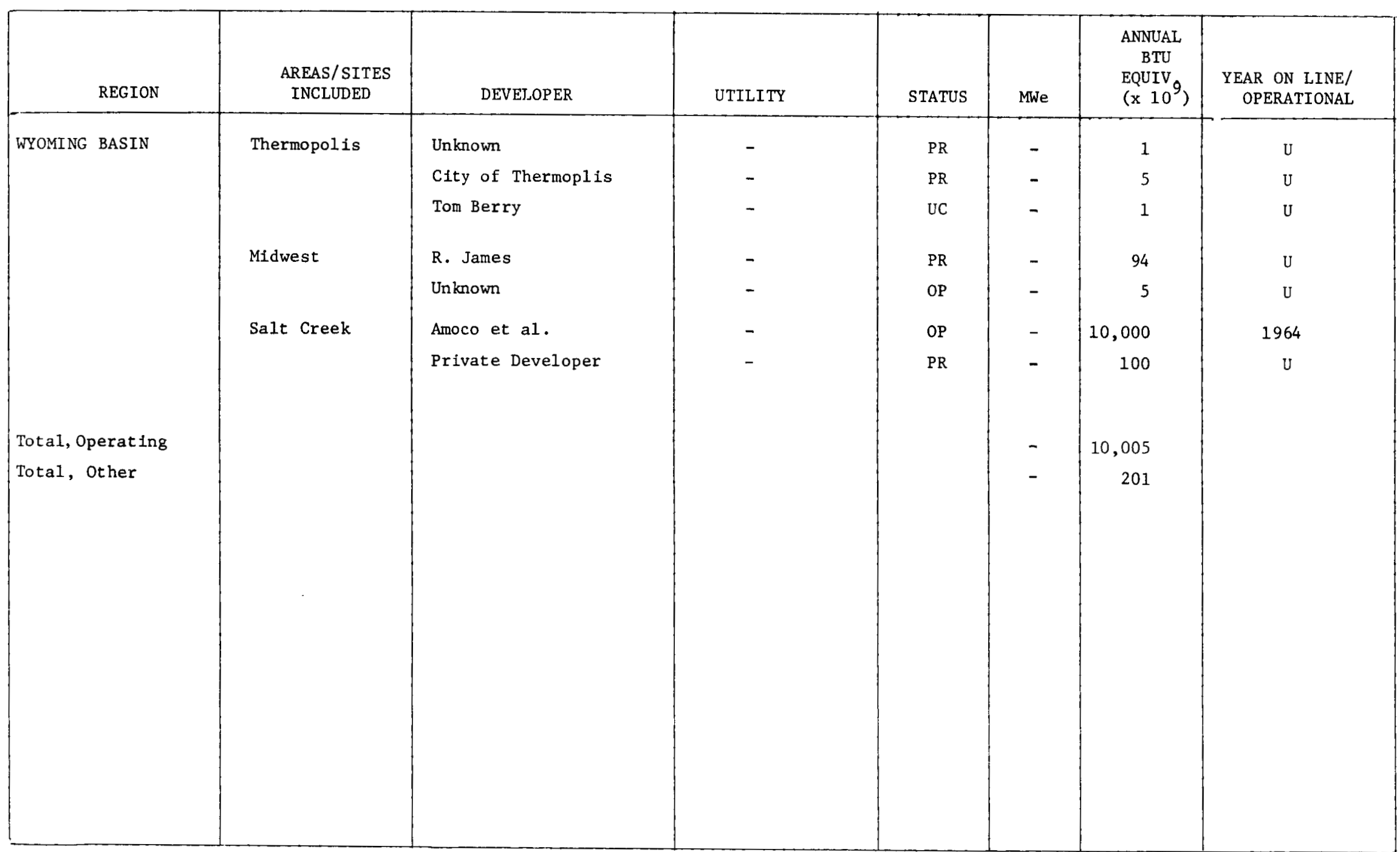

\# For direct heat projects, construction begins with preliminary development activities such as exploratory drilling. 
-

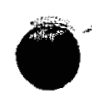




\section{RECENT MAJOR ACTIVITIES (GENERAL)}

\section{DIRECT HEAT}

\section{- HUD Announces Winners Under Joint HUD/DOE District Heating Solicitation}

The Department of Housing and Urban Development has awarded district heating feasibility study grants to 28 communities. The cities of Berlin, Maryland; Santa Ana Pueblo, New Mexico; Thermopolis, Wyoming; and Union County, Oregon will focus on geothermal heating systems. Missoula, Montana and Provo, Utah will consider geothermal energy along with other sources such as waste wood burning. Awardees proposing heat pump applications include Bellows Falls, Vermont and Campbellsville, Kentucky. Springfield, Massachusetts will investigate feasibility of using heat pumps along with cogeneration.

Of the 600 cities expressing an interest in district heating, 110 submitted proposals and 35 of these proposed assessments of geothermal or heat pump systems. Although the majority of geothermal proposals came from states with a large known geothermal potential, proposals were also submitted by such nontraditional states as Vermont, Maryland, Kentucky, and Massachusetts.

Other cities selected were Albany, New York; Allentown, Pennsylvania; Atlanta, Georgia; Atlantic City, New Jersey; Baltimore, Maryland; Cambridge, Massachusetts; Columbus, Ohio; Dayton, Ohio; Devil's Lake, North Dakota; Ecorse, Michigan; Fort Wayne, Indiana; Galax, Virginia; Gary, Indiana; Holland, Michigan; Lawrence, Massachusetts; Lewiston, Maine; New York, New York; Norwalk, Connecticut; and RIchmond, Indiana.

Funding for DOE Phase II, the design stage, has been delayed. Funding for the Phase II solicitation may be rescinded by Congress.

$$
\text { Source: GRC, 5/81. }
$$

\section{LEASING}

\section{- USGS Sets Competitive Lease Sale Dates}

The Conservation Division of the U.S. Geological Survey has set dates for competitive geothermal lease sales during 1981-1982. The selected leases in Known Geothermal Resource Areas that the agency plans to offer are as follows:

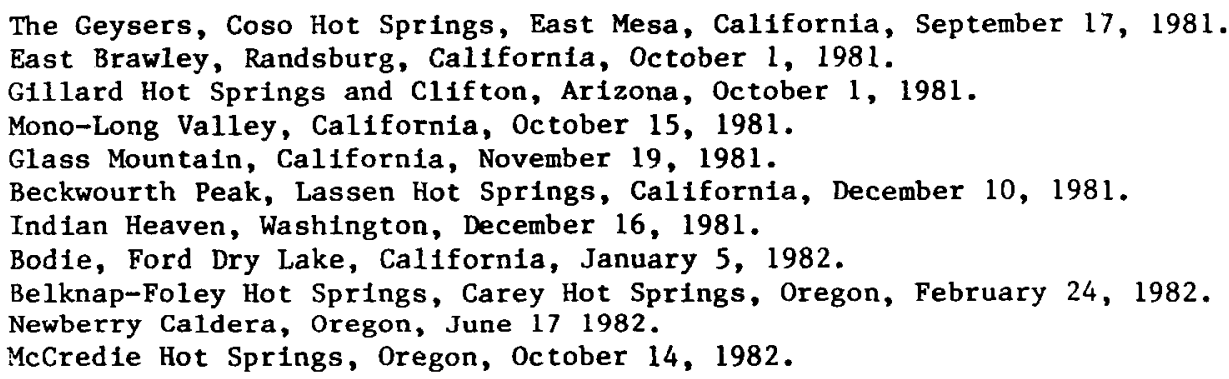

All lease sale notices are tentative until public notice is issued 30 days prior to the sale.

$$
\text { Source: PIC NGS, 6/26/81. }
$$

\section{- Federal Land Returned}

The Department of the Interfor (DOI) has revoked the withdrawal of about 680,000 acres of federal land at scattered sites in eleven western states. Each revocation restored the formerly withdrawn area to uses which had been prevented by the withdrawal. The action has been termed by the Interfor Assistant Secretary for Land and Water Resources as a "positive move toward accelerated multiple use of....public land."

Source: The Geyser, 5/20/81.

\section{- Hunts ActIve in Geothermal Leasing}

Individuals, trusts, and corporations of the Texas Hunt family reportedly hold about one sixth of all federal land leased for geothermal exploration. Interior Department records show that the Hunts hold 252 of the 1600 geothermal leases which have been issued by the BLM, giving the family control of about 480,000 acres of the 2.9 million acres of federally leased geothermal land. Applications are pending for an additional 435,000 acres. Though the Hunts were thwarted in their 
efforts to corner the market in soybeans and silver, they have avolded the federal 1imitation of 20,480 acres per state for an individual leaseholder by acquiring leases in 20 different names, including individuals, trusts, and corporations. Most of the Hunt investments have been made in noncompetitive leases in Nevada, New Mexico, Oregon, Idaho, and Utah. To date, they have reported no geothermal discoveries. An investigation of Hunt famtly activities by the House Subcommittee on Commerce, Consumer and Monetary Affalrs has been expanded to include geothermal leasing activity.

Source: Washington Post, $3 / 1 / 81$

Tribune, Oakland, CA, 3/1/81

Phoenix Repub11c, 3/2/81

\section{OUTREACH AND TECHNICAL ASSISTANCE}

\section{- Technical Assistance Program Status Reported}

The Division of Geothermal and Hydropower Technologies, Department of Energy supports a technical assistance program, whereby interested potential users of geothermal energy may recelve up to 100 hours of technical and economic assistance. Technical assistance centers funded by DGHT are the Applied Physics Laboratory; EG\&G, Idaho (Idaho National Englneering Laboratory); the Oregon Institute of Technology; Gruy Federal, Inc., and the University of Utah Research Inst1tute. Assistance ranges from basic engineering evaluations to geothermal resource analyses. Information about assistance provided by one of these centers, EG\&G, Idaho, is highlighted here.

From December 1980 through June 1981, EG\&G, Idaho handled about 76 requests for technical assistance; 44 of these cases were new requests made during this period. A portion of these requests were completed by EG\&G, Idaho; others were forwarded to subcontractors for consideration. Some cases were referred to the Moderate and Low Temperature Reservoir Engineering Program and to State Geothermal Commercialization Teams. Twenty-seven cases were completed by EG\&G during this period. A summary of these cases by type of application follows.

EG\&G, IDAHO COMPLETED TECHNICAL ASSISTANCE REQUESTS

BY APPLICATION TYPE

DECEMBER 1980 - JUNE 1981

\begin{tabular}{|c|c|c|c|c|c|}
\hline MONTH & $\begin{array}{l}\text { RESIDENTIAL } \\
\text { SPACE HEAT }\end{array}$ & $\begin{array}{l}\text { COMMERCIAL } \\
\text { SPACE HEAT }\end{array}$ & AGRICULTURAL & $\begin{array}{c}\text { INDUSTRIAL } \\
\text { PROCESS } \\
\text { HEAT }\end{array}$ & OTHER \\
\hline December 1980 & 2 & 1 & 2 & 1 & - \\
\hline January 1981 & - & 2 & - & - & 1 \\
\hline Febrüury 1981 & 1 & 3 & 2 & - & - \\
\hline March 1981 & - & - & - & - & - \\
\hline April 1981 & 1 & - & 2 & - & 1 \\
\hline May 1981 & 1 & - & 2 & - & - \\
\hline June 1981 & 2 & 2 & - & 1 & - \\
\hline TOTAL & 7 & 8 & 8 & 2 & 2 \\
\hline
\end{tabular}

Source: EG\&G Idaho, $7 / 81$. 


\section{- Geothermal Leasing Bills Introduced}

Legislation to streamline federal geothermal leasing and permitting has been introduced in both houses of Congress. The bills are H.R. 4067, introduced by Rep. James Santini (Nevada), and S. 1516, sponsored by Senators James McClure (Idaho) and John Warner (Virginia). The two bills, similar in nature, are substantively supported by the Administration, but Department of Interior witnesses at a July hearing on the legislation stated that the Administration had not established a position on certain elements of H.R. 4067 relating to competitive leasing and lease readjustment intervals. As a result, action on the bill by both the House and the Senate has been indefinitely deferred.

Source: DOE, 10/9/81.

\section{- Geothermal Tax Bills Introduced}

Rep. Tony Hall (Ohio) and Sen. Riegle (Michigan) have introduced legislation to clarify the applicability of geothermal energy tax credits for residential and commercial applications. These bills (H.R. 4091 and S. 1684) would override IRS regulations which currently (1) limit the credits to systens using resources with temperatures of $50^{\circ} \mathrm{C}$ or higher and (2) prohibit application of the credits to systems which use geothermal energy in conjunction with another energy source (e.g. for peaking or topping). No action on the bills has been scheduled by the Ways and Means or Finance Committees.

\section{- Geothermal Insurance Available}

Source: DOE, $10 / 9 / 81$

The Insurance Company of North America (INA) has formed a new insurance group providing comprehensive coverage to the energy industry. INA's Energy Insurance Group, based in Philadelphia, can provide insurance against the financial risk of geothermal reservoir failure, thus making a geothemal project a more attractive financial venture. Indemnification is based on the insured's loss resulting from resource inadequacy.

\section{RESEARCH AND DEVELOPMENT}

$$
\text { Source: } \quad \text { DOE, } 7 / 13 / 81 \text {. }
$$

\section{- Nitrogen Drilling Fluids Reduce Corrosion}

Results of a field study test of special drilling fluids indicate a marked decrease in drillpipe corrosion in geothermal wells. Sandia National Laboratories recently tested a nitrogen drilling fluid and compared results with a chemically treated drilling fluid at Union's Baca \#22 at the Valles Caldera in New Mexico. Corrosion rates were reported as "l0 times slower" using the nitrogen drilling fluid. Sandia is working to develop a portable generator which can produce nitrogen at the well site.

Source: EG\&G Idaho, $7 / 14 / 81$.

\section{- Fenton Hill Operations Continue}

Drilling equipment stuck in one of the wells at the Fenton Hill, New Mexico experimental hot dry rock site has been retrieved, leaving the hole apparently clear. Despite the long history of drilling problems and the risk of more failures, drilling will be resumed in hopes of reaching the target of approximately $50 \mathrm{MWt}$ production from a man-made fracture system.

$$
\text { Source: DOE, 7/24/1981. }
$$

\section{- Reservoir Stimulation at Baca Planned}

Union is planning a massive hydraulic fracture of the Baca \#20 well in August. At approximately $475^{\circ} \mathrm{F}$, the $8000 \mathrm{bbl}$ (plus 200,000 1bs. Of proppant) treatment will be the hottest ever attempted.

Source: DOE, $7 / 24 / 81$.

\section{- Gravity Head Binary Project Continuation Sought}

Sperry is pursuing negotiations with different utilities and Magma Power in hopes of finding a way to continue the gravity head binary project following loss of the special large diameter well at East Mesa. Since repairing the existing well does not appear to be a viable option, Sperry is seeking funds for drilling a new well, testing the turbine-pump unit and building and testing a complete gravity-head binary system. The program suffered a setback on June 22 when the 1 iner recently cemented in the upper 1800 feet of the well collapsed, blocking the hole at a depth of about 400 feet. 


\section{ENVIRONMENT}

- EIC $\mathrm{H}_{2}$ S Process Being Developed

The EIC Company is working on its copper sulfate $H_{2} S$ abatement process to extend the applicability of the present process to a wider range of geothermal resources. They are changlng the process chemistry to produce more valuable by-products.

Source: DOE, $7 / 24 / 81$.

- Alternative $\mathrm{H}_{2}$ S Abatement Systems Explored

Representatives of DOE's San Francisco Operations office (SAN) met with MCR Geothermal to discuss costs and benefits of an entirely new $\mathrm{H}_{2} \mathrm{~S}$ abatement system developed by UOP, Inc. under DOE contract. Comparisons are being made between the UOP geothermal catalyst (GEOCAT) and the EIC cOpper sulfate (CUPRASIL) systems. MCR is exploring alternative systems and is considering working with UOP to field test GEOCAT. This system might be used for control of hydrogen sulfide from wells on bleed, required for future well drilling permits from the Lake County Air Pollution Control District, which controls power plants at The Geysers.

Source: DOE, 7/20/81. 


\section{REPORTS AND PUBLICATIONS}

This section presents abstracts and references of significant reports of interest to members of the geothermal community. The information is obtained from the source 1 isted with each entry.

\section{- Geophysical Maps of the Cascade Range in Oregon}

The Oregon Department of Geology and Mineral Industries has recently released three sets of maps in its Geological Map Series. The new maps are GMS-15, a gravity map covering the northern Cascades in Oregon from the Washington state line to Redmond, and GMS-16 (gravity) and GMS-17 (aeromagnetic) covering the southern Cascades in Oregon from Crater Lake to the California state line. The central Cascades have been covered by maps published by DOGAMI in 1978 as GMS-8 and GMS-9.

Avallable from: Oregon Department of Geology

and Mineral Industries

1005 State office Building

Portland, Oregon 97201

Source: DOE-Region X Geothermal Energy Report, 5/81

- Geotherma1 Resources of the Eastern United States

The hydrothermal resources of the 35 states east of the Rocky Mountains (excluding the Dakotas) have been compiled by J.L. Renner and T.L. Vaught of Gruy Federal, Inc. The resource definition data was derived from the open literature and the files of a number of state geological offices. The report is entitled Geothermal Resources of the Eastern United States (DOE/NVO/1558-7) and costs $\$ 5.25$ for a paper copy and $\$ 3.00$ for microfiche.

Available from: NTIS

U.S. Department of Commerce

5285 Port Royal Road

Springfield, VA 22161

Source: Geothermal Energy, Vol. 9, No. 3, 3/81

- New Weekly Newsletter

Federal Lands is a new weekly newsletter published by McGraw Hill. It focuses on the development of fuels and nonfuel minerals on federal lands both on-shore and off-shore. For subscription information contact McGraw-Hill.

Available from: McGraw-Hill

Federal Lands

1221 Avenue of the Americas

New York, New York 10020

(212) $997-6410$

(800) 223-6180 (Toll-free)

Source: Geothermal Energy, Vo1. 9, No. 3, 3/81

- Advances in European Geothermal Research

The proceedings of the Second International Seminar on the Results of European Communities Geotherma1 Energy Research includes more than 70 papers dealing with regional and local exploration and exploitation of geothermal resources. Edited by A.S. Strub and P. Ungemach this volume contains about 1100 pages and costs $\$ 63$.

Available from: Kluwer Boston,Inc. (U.S./Canadian Distributor)

160 old Derby Street

Hingham, MA 02043

Source: Geothermal Energy, Vo1. 9, No. 1, 1/81

- Minerals Recovery Research

The results of a Bureau of Mines mineral recovery research program is reported in We11 Engineering and Sampling Variables in the Evaluation of Geobrines by W.D. Riley and others. The results indicate the importance of the operating and engineering history, the operating parameters during sampling, and the method of sampling in order to evaluate the chemical analyses. This report (RI 8465) is distributed free of charge. 
Avallable from: Section of Publications

Bureau of Mines

U.S. Department of the Interior

4800 Forbes Avenue

Pittsburgh, PA 15213

Source: Geothermal Energy, Vo1. 9, No. 1, 1/81

- California Energy Almanac

The Office of Lieutenant Governor Mike Curb and the State Commission for Economic Development have published a list of more than 3100 "public and private entities in California which directly deal with energy and the environment." The cost of this 477 page volume, The California Energy Almanac, is $\$ 10$.

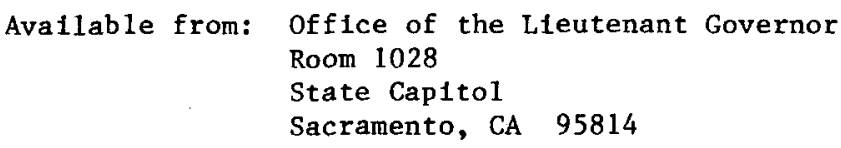

- Reports Published by the University of Utah Research Institute

Periodically, the Earth Science Laboratory at UURI publishes reports and open file material generated under Department of Energy contracts. For a 11sting of current material contact:

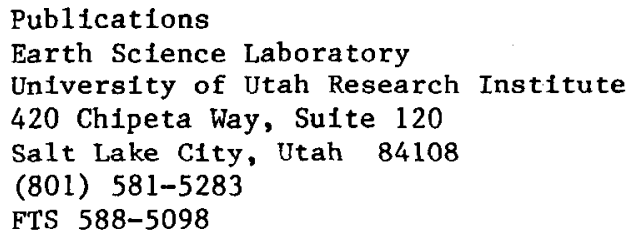


IV. DIRECTORY

This section presents the names and addresses and/or phone numbers of individuals in the geothermal community, particularly the participants in the Geothermal Progress Monitor system.

DOE HEADQUARTERS

James Bresee

Acting Director,

Geothermal and Hydropower Technologies Division

Conservation and Renewable Energy

(202)252-5340

\section{REGIONAL OFFICES}

The DOE Regional offices were closed on October 1, 1981. Their functions have been transferred to appropriate DOE Operations offices.

\section{OPERATIONS OFFICES}

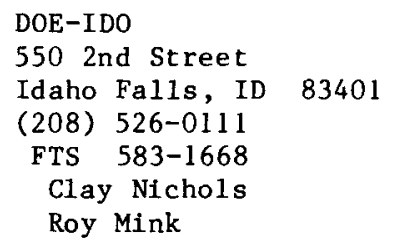

DOE-NVO

P.0. Box 14100

Las Vegas, NV 89114

(702) 734-3251

Ron Stearns

Joe Fiore

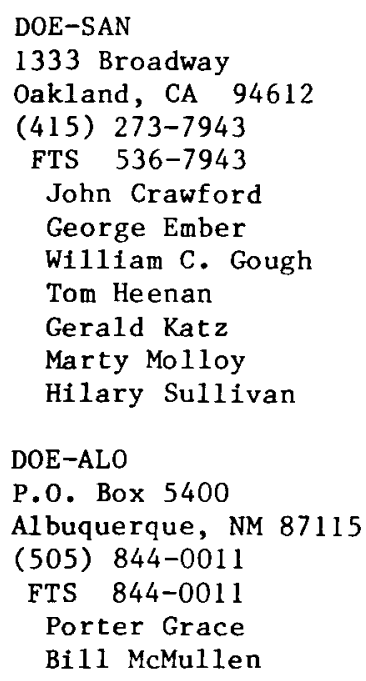

OTHER GOVERNMENT

Jack McArdle

Minerals and Geology

U.S. Forest Service

Department of Agriculture

Room 803, Rosslyn Plaza East

P.O. Box 2417

Washington, D.C. 20013

(703) 235-8010

Forest Service Regions

\section{Region I}

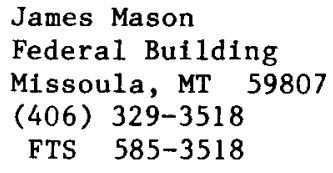

\section{Region II}

Craig Losche

11177 West 8 th Avenue

Box 25127

Lakewood, CO 80225

(303) 234-3905

FTS 234-3905 
Gerald Gould

517 Gold Avenue, S.W.

Albuquerque, NM 87102

(505) 766-2006

FTS 474-2006

Region V

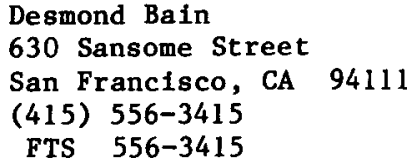

Region VIII

Ed Read

1720 Peachtree Road, N.W.

Atlanta, GA 30309

(404) 881-2692

FTS 423-2921

\section{Region X}

Wesley Moulton

Box 1628

Juneau, AK 99802

(907) 586-7271

Department of the Interior

Assistant Secretary

Energy and Minerals

Department of the Interior

18 th and C Street, N.W.

Washington, DC 20240

(202) 343-2186

Assistant Secretary

Mineral and Water Resources

Department of the Interior

12201 Sunrise Valley Drive

Reston, VA 22092

(703) $860-7481$

Director

Bureau of Mines

Department of the Interfor

2401 E Street, N.W.

Washington, DC 20240

(202) 634-1300

\section{Director}

National Park Service

Department of the Interior

18 th and C Street, N.W.

Washington, DC 20240

(202) 343-4621
Norman Stark, Geologist

U.S. Forest Service

Department of Agriculture

324 - 25th Street

Ogden, UT 84401

(801) 626-3264

FTS 586-3264

Region VI

Merle Hofferberg

319 S.W. Pine Street

Portland, OR 97208

(503) 221-2921

FTS 423-2921

Region IV

Jack Jacks

$638 \mathrm{~W}$. Wisconsin Avenue

Milwaukee, WI 53203

(414) 224-3614

FTS $362-3614$

Assistant Secretary

Land and Water Resources

Department of the Interior

18th and C Street, N.W.

Washington, DC 20240

(202) 343-2191

Director

Bureau of Land Management

Department of the Interior

18 th and $\mathrm{C}$ Street, N.W.

Washington, DC 20240

(202) 343-3801

Director

Fish and Wildlife Service

Department of the Interior

18 th and $\mathrm{C}$ Street, N.W.

Washington, DC 20240

(202) 347-4717

Commissioner

Water Power and Resources

Department of the Interior

18 th and C Street, N.W.

Washington, DC 20240

(202) 347-4157 
Bureau of Land Management

Department of the Interior 2800 Cottage Way

Sacramento, CA 95825

(707) $462-3873$

Jack Lahr

U.S. Geological Survey

Geothermal Research Program

Department of the Interior

12201 Sunrise Valley Drive

Reston, VA 22092

(703) $860-7411$

U.S. Geological Survey

Conservation Division

office of the Area Geothermal

Supervisor

2465 East Bayshore Road

Suite 400

Palo Alto, CA 94303

(415) 323-8111

FTS 467-2884

Bruce Blakely

CONTRACTORS SUPPORTING THE GEOTHERMAL PROGRESS MONITOR

MITRE Corporation

Geothermal Group, MS-W227

1820 Dolley Madison Blvd.

McLean, VA 22102

(703) $827-6000$

Dan Entingh

Robert Gerstein

Lisa Kenkeremath

Mary Murphy

EG\&G, Idaho, Inc.

P.O. Box 1625

Idaho Falls, ID 83401

(208) 526-1458

Joe Hanny

Bob Schultz

Bil1 Toth

Ed DiBello

Ron Hilker

Oregon Institute of Technology

Geo-Heat Utilization Center

Klamath Falls, OR 97607

(503) 882-6321

Paul J. Lienau

Gordon Gene Culver

John W. Lund

Charles V. Higbee

Willtam Johnson

Debra Justus

Gene P. Ryan
U.S. Geological Survey

Office of Resource Analysis

GEOTHERM

Department of the Interior

345 Middlefield Road - MS 84

Menlo Park, CA 94025

(415) 323-8111, Ext. 2906

Jim B1iss

Kar1 Duscher

Bureau of Land Management

Department of the Interior

$18 \mathrm{th}$ and $\mathrm{C}$ Street, N.W.

Washington, DC 20240

(202) 343-7722

Albert E. Theberge

National Oceanic and Atmospheric Administration

Data Mapping Group, Code D64

325 Broadway

Boulder, CO 80303

(303) 497-6124

FTS 320-6124

\author{
New Mexico Energy Institute \\ Box 3-PSL \\ Las Cruces, NM 88003 \\ (505) 522-9349 \\ Roy Cunniff \\ Kim Knauf \\ Paul McDevitt \\ Joe Marlin \\ Patrick 0'Dea \\ University of Utah \\ Research Institute \\ 420 Chipeta Way \\ Suite 120 \\ Salt Lake City, UT 84108 \\ (801) 581-5283 \\ Duncan Foley \\ Mike Wright \\ Debbie Struhsacker
}




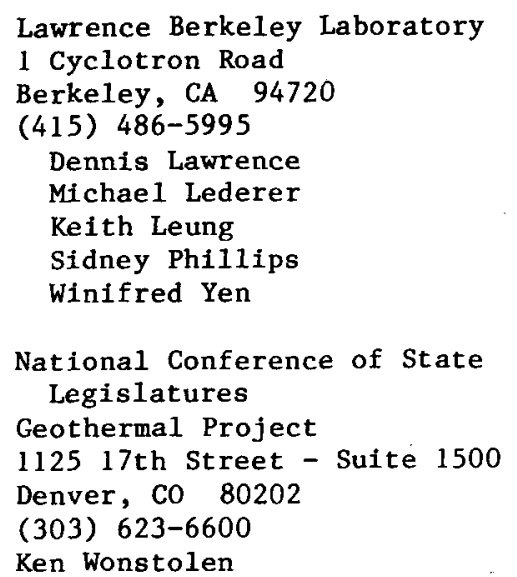

INTERAGENCY GEOTHERMAL COORDINATING COUNCIL

\section{Chairman}

Mr. Joseph J. Tribble

Assistant Secretary

Conservation and Renewable Energy

Department of Energy

Washington, DC 20585

252-9220

Mr. Stephen J. Bollinger

Assistant Secretary for

Community Planning and Development

Department of Housing and Urban Development

Washington, DC 20410

$755-6270$

Dr. Paul Craig Roberts

Assistant Secretary for

Economic Policy

Department of the Treasury

Washington, DC 20220

$566-2551$

Dr. Daniel N. Miller Jr.

Assistant Secretary for

Energy and Minerals

Department of the Interior

Washington, DC 20240

343-2186

Assistant Administrator for

Research and Development

Environmenta1 Protection Agency

401 M Street, S.W.

Washington, DC 20460

$755-2600$

\section{Staff Committee}

\section{Chairman}

James C. Bresee

Acting Director

Geothermal and Hydropower Technologies Division Conservation and Renewable Energy

Department of Energy

$252-5340$
Gruy Federal, Inc.

2001 Jefferson Davis Hwy.

Suite 701

Arlington, VA 22202

(703) $892-2700$

Joe1 Renner
Mr. Robert G. Dederick

Assistant Secretary for Economic Affairs Department of Commerce

Washington, DC 20230

$377-3523$

Mr. John B. Crowell, Jr. Assistant Secretary for

Natural Resources and Environment

Department of Agriculture

Washington, DC 20250

447-7173

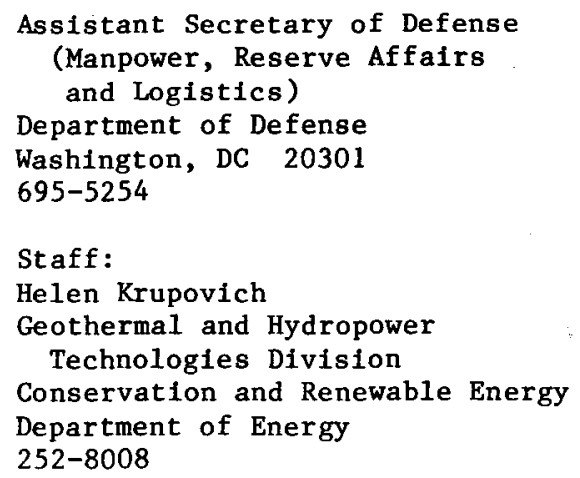

Staff:

Helen Krupovich

Geothermal and Hydropower

Technologies Division

Conservation and Renewable Energy

Department of Energy

252-8008

Mr. John P. McArdle

Minerals and Geology

U.S. Forest Service

Department of Agriculture.

Room 1208, Rosslyn Plaza East

P.O. Box 2417 (RPE 803)

Washington, DC 20013

235-9886 
Mr. David R. Berg

Energy Process Division (RD-681)

Office of Research and Development

Environmental Protection Agency

Washington, DC 20460

755-0205

Mr. Wyndham $\mathrm{Clarke}$

Energy Systems Specialist

office of the Assistant Secretary

for Community Planning and Development

Department of Housing and Urban Development

Washington, DC 20410

755-6290

Mr. Frederick T. Knickerbocker

Acting Director

Economic Policy Staff

Office of Assistant Secretary for

Economic Affairs

Department of Commerce

$14 \mathrm{th}$ and Constitution Avenue, N.W.

Washington, DC 20230

377-2405

Mr. Thomas A. Ladd

Energy and Utilities Division

NAVFAC III

Naval Facilities Engineering Command

Room 10507

200 Stova11 Street

Alexandria, VA 22332

325-0102

\section{Budget and Planning Working Group}

\section{Non-DOE Members of IGCC/BPWG}

Mr. Larry Bauer

Fluid Minerals Branch

Conservation Division

U.S.G.S. National Center

M.S. 650

Reston, Va 22092

Alternate: Malcolm Furbush

Mr. David R. Berg

Energy Processes Division (RD 681)

office of Research and Development

Environmental Protection Agency

Washington, DC 20460

755-0205

Mr. Robert Groberg

Energy Adviser

Assistant Secretary for Community

Planning and Development

Department of Housing and

Urban Development

4517 th Street, S.W. Room 7270

Washington, DC 20410

755-3409
Mr. William E. Steger

Office of Energy Policy

office of Assistant Secretary for

Economic Policy

Department of Treasury

Washington Building, Room 921

Washington, DC 20220

376-0298

Alternate: Ms. Eleanor Bryan

Mr. Andrew L. Strasfogel

Special Assistant

office of Assistant Secretary

Special Assistant

Energy and Minerals

Department of the Interior

Room 6635

18 th and $E$ Street, N.W.

Washington, DC 20240

343-2136

Staff:

Helen Krupovich

Geothermal and Hyropower

Technologies Division

Conservation and Renewable Energy

Department of Energy

252-8008

Mr. Karl Duscher

Division of Onshore Energy Resources

Bureau of Land Management

Department of Interior

Room 3550

18 th and C Streets, N.W.

Washington, DC 20240

343-7722

Mr. Wayne A. Fernelius

Planning Policy Staff

Bureau of Reclamation

Department of Interior (Room 7451)

Washington, DC 20240

343-5275

Mr. Joseph F. Gustaferro

Office of Economic Affairs

Department of Commerce

Room 1898

14 th and Constitution Avenue, N.W.

Washington, DC 20230

377-4363 
Mr. Edward J. Doheney

Energy and Utilities Division

NAVFAC 111

Naval Facilities Engineering Command

200 Stovall Street

Alexandr1a, VA 22332

325-0102

Mr. John P. McArdle

Minerals and Geology

Forest Service

Department of Agriculture

P.0. Box 2417

Washington, DC 20013

235-9886

(Delivery Address: $\mathrm{Rm} 1207$,

1621 N. Kent St., Rosslyn, VA)

Dr. Thomas Henrie

Bureau of Mines

Department of Interior

Room 1017

2401 E Street, N.W.

Washington, DC 20241

634-1305

DOE Members of IGCC/BPWG

Chatrman:

Dr. Fred H. Abel

Geothermal and Hydropower

Technologies Division

Conservation and Renewable Energy

252-8082

Dr. Robert P. Blaunsteln

Manager, Solar, Geothermal

Conservation Assessment Program

ASEV/DOE

Room D401, M.S. D423, Germantown

Washington, DC 20545

353-5849

Mr. Daniel Dick

Leasing Policy Development Division

FE

Room 2115, Federal Building, M.S. 2109

12 th and Pennsylvania Avenue, N.W.

Washington, DC 20461

633-8244

Alternate: John Broderick

Mr. Frank C. Emerson

Office of Integrative Analysis

EIA, Department of Energy

M.S. 4530, Federal Bullding

12 th and Pennsylvania Avenue, N.W.

Washington, DC 20461

633-8555
Mr. Willard Spaulding, Jr.

Office of Ecological Services

U.S. Fish and Wildlife Service

Department of Interior

$1375 \mathrm{~K}$ Street, N.W. (Suite 401)

Washington, DC 20240

343-5656

Alternate: Dick Forrester, 343-6025

Mr. Allan Kover

Office of Geochemistry and Geophysics

U.S.G.S., Department of Interfor

National Center, M.S. 906

Reston, VA 22092

860-6531

Alternate: Donald W. Klick
Mr. Charles R. Mandelbaum Office of Program Analysis Office of Energy Research Department of Energy Al-4024, Century 21 Building Germantown, MD 20545

353-3122

Mrs. Ursula Gillis

Office of Policy Evaluation

Department of Energy

Room 7H021, Forrestal Buflding

1000 Independence Ave., S.W.

Washington, DC 20585

252-4452

Mr. William I. Wheelock

Interconnection Systems Analysis

FERC/DOE 825 N. Capitol

400 First Street, N.W., Room 504D

Washington, DC 10426

376-9266

Staff:

Helen Krupovich

Geothermal and Hydropower

Technologies Division

Conservation and Renewable Energy 252-8008 
Randall C. Stephens, Chairman

Geothermal and Hydropower Technologies Division

Conservation and Renewable Energy

Department of Energy

$252-5778$

Bernard B. Chew

Director, Division of Interconnection and Systems Analysis

Office of Electric Power Regulation

Federal Energy Regulatory Commission

MS 504

400 lst Street, N.W.

Washington, DC 20585

(202) 376-9264

Seymour Fiekowsky

Office of Tax Analysis

Department of Treasury

MS 4054

15th and Pennsylvania Ave., N.W.

Washington, DC 20220

(202) 566-8282

Gerald R. Daniels

U.S. Geological Survey

Department of the Interior

MS 600

12201 Sunrise Valley Drive

Reston, VA 22092

(703) $860-7535$

Thomas Ladd

Geothermal Program Manager

Naval Facilities Engineering

Code 111

200 Stoval1 Street

Alexandria, VA 22332

(703) 325-0102

James Mackenzie

Office of Energy Programs

Council on Environmental Quality

722 Jackson Place, N.W.

Washington, DC 20006

(202) 395-4946

Dale Zimmerman

Bureau of Land Management

Department of the Interior

MS 3560

18 th and C street, N.W.

Washington, DC 20240

(202) $343-2718$
Joseph F. Gustaferro

Office of Ocean Resource and

Scientific Policy Coordination

Department of Commerce

MS 5717

14th \& Constitution Ave., N.W. Washington, DC 20230

(202) 377-4363

Jack McArdle

Minerals and Geology

U.S. Forest Service

Department of Agriculture

Room 803, Rosslyn Plaza East

P.0. Box 2471

Washington, DC 20013

(202) 235-8010

David Berg

Office of Environmental

Engineering and Technology

Environmental Protection Agency

MS RD-681

401 M Street, S.W.

Washington, DC 20460

(202) 755-0205

R. H. Lawton

Leasing Policy Development office DOE/RA-342.1

12 th \& Pennsylvania Ave., N.W.

Washington, DC 20461

(202) 633-9326

James J. Busse

Division of Power Supply and Reliability

Office of Utility Systems

Economic Regulatory Administration

Department of Energy

2000 M Street, N.W.

MS 4002

Washington, DC 20461

(703) 254-8260

Anthony M. Carey

Energy Adviser

Assistant Secretary for Community

Planning and Development

Department of Housing and

Urban Development

4517 th Street, S.W.

Washington, DC 20410

(202) 755-6267

Bruce Engelbert

of fice of Policy and Evaluation $\mathrm{DOE} / \mathrm{PE}$

Forrestal Building - Room 7E-088

1000 Independence Avenue, S.W.

Washington, DC 20585

(202) 252-6433 
1100 L Street, N.W.

Washington, DC 20240

(202) 523-5152

Leasing and Permitting Pane1

Winston B. Short, Chairman Natural Resource Specialist Department of the Interior 18 th and $\mathrm{C}$ Street, N.W. Washington, DC 20240

(202) 343-7722

Theodore Holland Geothermal Speciallst Bureau of Land Management Div. of Tech. Services $550 \mathrm{~W}$. Fort Street Boise, ID 83724

(208) 554-9536

Bruce Hellier

Chief, Engineering Section office of the Area Geothermal

Supervisor

U.S. Geological Survey

2465 East Bayshore Road

Palo Alto, CA 94303

FTS 467-2841

Norman Stark, Geologist

U.S. Forest Service

Department of Agriculture

Minerals Assessment Branch

324 - 25th Street

Ogden, UT 84401

(801) 626-3264

FTS 586-3264

Robert Conover, Field Solicitor Office of the Field Solicitor Department of the Interior

Suite 104

Central Plaza Bullding

3610 Central Avenue

Riverside, CA 92506

Daniel Dick

DOE/RA-451, Rm 2115

Federal Building

12th \& Pennsylvania Ave., N.W.

Washington, DC 20461

(202) 633-9437

\section{Environmental Controls Panel}

David R. Berg, Chairman

Office of Environmental

Engineering and Technology

Environmental Protection Agency MS RD-681

401 M Street, S.W.

Washington, DC 20460

(202) 755-0205
Kar1 Duscher

Bureau of Land Management

Department of the Interior

18 th and $C$ Street, N.W.

Washington, DC 20240

(202) 343-7722

Gerald R. Daniels

U.S. Geologic Survey

Department of the Interior MS 600

12201 Sunrise Valley Drive

Reston, VA 22092

(703) $860-7535$

Jack McArdle

Minerals and Geology

U.S. Forest Service

Department of Agriculture

Room 803, Rosslyn Plaza East

P.0. Box 2471

Washington, DC 20013

(202) 235-8010

Kenneth Lee, At torney

Department of the Interior

18 th and C Street, N.W.

Washington, DC 20240

(202) 343-4803

Randa11 C. Stephens

Geothermal and Hydropower Technologies Division

Conservation and Renewable Energy

Department of Energy

(202) 252-5778
Douglas Boehm

office of Environmental

Control Technology

DOE/Germantown

Washington, DC 20545

(202) 353-5511 
Clifton McFarland

Geothermal and Hydropower Technologies Division Conservation and Renewable Energy

Department of Energy

(202) 252-8076

Sie Ling Chiang

U.S. Geological Survey

Department of the Interior

MS 600

12201 Sunrise Valley Drive

Reston, VA 22092

(703) $860-7136$

Kar1 Duscher

Bureau of Land Management

Department of the Interior

18 th and C Street, N.W.

Washington, DC 20240

(202) 343-7722

William Spaulding, Jr.

Office of Ecological Services

U.S. Fish and Wildlife

Department of the Interior

18 th and $C$ Street, N.W.

Washington, DC 20240

(202) 343-5656

Robert E. Oliver

Geothermal and Hydropower Technologies Division Conservation and Renewable Energy

Department of Energy

(202) 252-8083

\section{Financial/Grants Task Force}

Lachlan Seward, Chairman

Geothermal and Hydropower Technologies Division

Conservation and Renewable Energy

Department of Energy

(202) 252-5334

M. David Feld

Farmers Home Administration

Department of Agriculture

Room 6305

South Agriculture Building

Washington, DC 20250

(202) 633-8774

John C. Thalmayer

Economic Development Administration

Department of Commerce

Room 7517

Main Commerce Building

Washington, DC 20230

(202) 377-2162
Robert P. Hartley

Environmental Protection Agency

Cincinnati, OH 45268

(513) $684-4334$

FTS 684-4334

A. David Allen

Geothermal and Hydropower

Technologies Division

Conservation and Renewable Energy

Department of Energy

(202) 252-8078

Thomas Ladd

Geothermal Program Manager

Naval Facilities Engineering

Code 111

200 Stovall Street

Alexandria, VA 22332

(703) 325-0102

Gerald Katz

DOE-SAN

1333 Broadway

Oakland, CA 94612

(415) 273-7943

FTS 536-7943

Walter Schlump f

U.S. Forest Service

Department of Agriculture

P.0. Box 2417

Washington, DC 20013

(202) 235-1750

Anthony M. Carey

Energy Adviser

Assistant Secretary for Community

Planning and Development

Department of Housing and

Urban Development

4517 th Street, S.W.

Washington, DC 20410

(202) 755-6267

Thomas B. Heath

Director

Energy Management and Utilization Division

Department of Agriculture

14th \& Independence Ave., S.W.

Washington, DC 20250

(202) 447-3067 
The following list of state teams is acurate as of September 1, 1981. Some of these teams are expected to be phased out over the next few months.

Stanley Green

Utah Department of Natural Resources

Division of Water Rights

231 East 400 South

Salt Lake City, UT 84111

(801) 533-6071

\section{Phil Lidel}

Office of Energy Policy

Capitol Lake Plaza

Pierre, SD 57501

(605) 773-3603

Noel Clark

Nevada Department of Energy

400 West King Street

Suite 106

Carson City, NV 89710

(702) 885-5157

Gordon Bloomquist

Washington State Energy office

400 E. Union Street

Ol ympia, WA 98504

(206) $754-0774$

George Scudella

Consultant

New Mexico Energy and Minerals

Department

113 Washington Avenue

Santa Fe, NM 87501

(505) $827-2471$

Larry Goldstone

Department of Chemical Engineering

University of Arizona

2045 N. Forbes Blvd.

Suite 106

Tucson, AZ 85721

(602) 626-4391

Don Markle

Alaska Division of Energy

and Power Development

Mackay Bullding - 7th Floor

338 Denali Street

Anchorage, AK 99501

(907) 276-0508

Chairman, State Geothermal

Advisory Committee

Department of Planning and

Economic Development

Box 2359

Honolulu, HI 96804

(808) $548-4195$
Richard H. Pear1

Colorado Geological Survey

Department of Natural Resources

1313 Sherman Street

Denver, CO 80203

(303) $866-2611$

Rick James

Geothermal Commercialization Office

Box 4096

University Station

Laramie, WY 82071

(307) 742-2054

Kevin McCarthy

Oregon Department of Energy

102 Labor and Industry Bldg.

Salem, OR 97310

(503) $378-2778$

Mike Chapman

Montana Department of Natural

Resources and Conservation

32 South E. Wing

Helena, MT 59601

(406) 449-4624

Bruce Gaugler

Geothermal Energy office

Natural Resources Council

State Capitol

Bismarck, ND 58505

(701) $224-2107$

Bill Eastlake

Idaho office of Energy

Statehouse

Bolse, ID 83720

(208) $334-3800$

Susan Brown

Californta Energy Commission

1111 Howe Avenue

Sacramento, CA 95825

(916) 924-2499

Daniel Anstine

State Energy office

P.0. Box 1401

Dover, DE 19901

(302) 736-5644 


\section{Principal Contacts}

STATE

Al abama

Alaska

Arizona

Arkansas

California

Colorado

Delaware

Georgia

Hawa11
NAME

PHONE NUMBER

Gary Wilson

(205) 349-2852

Ceological Survey of Alabama

P.O. Drawer 0

University, Alabama 35486

Ross Schaff

(907) 277-6615

Department of Natural Resources

Division of Geological and

Geophysical Surveys

3001 Porcupine Drive

Anchorage, Alaska 99501

Donald Turner

(907) $479-7460$

University of Alaska

Geophysical Institute

Falrbanks, Alaska 99701

Richard Hahman

(602) $626-4391$

Bureau of Geology and Mineral

Technology

2045 N. Forbes B1vd., Suite 106

Tucson, Arizona $\mathbf{8 5 7 0 5}$

William Laughlin

(Same as Arizona)

(602) $626-4391$

Forrest Bacon

(916) 322-9918

California Division of

Mines and Geology

28150 . Street

Sacramento, California 95816

Richard Pearl

Colorado Geological Survey

1313 Sherman Street

Room 715

Denver, Colorado 80203

Kenneth Woodruff

Delaware Geological Survey

University of Delaware

Newark, Delaware 19711

John Costain

Department of Geological Sctences

VPI \& SU

1046 Derring Hall

Blacksburg, V1rginia 24061

Chuck Helsley

Hawa1i Institute of Geophysics

(808) 948-8760

University of Hawali

2525 Correa Road

Honolulu, Hawail 96822

Donald Thomas

(303) 839-2611

(302) 738-2833

HI Institute of Geophysics

(808) $948-6482$

Univ. of Hawaii

2525 Correa Rd.

Honolulu, Hawail 96822 
/0 Statehouse Mai

Idaho Department of Water Resources

Boise, Idaho 83720

Kansas

Maryland

Mississippi

Nebraska

Nevada

New Jersey

New Mexico

New York

North Carolina
Don Steeples

(913) $864-4991$

Kansas Geological Survey

1930 Avenue "A"

Campus West

University of Kansas

Lawrence, Kansas 66044

(301) $338-7110$

Ken Schwarz

Maryland Geological Survey

Merryman Ha11

Johns Hopkins University

Baltimore, Maryland 21218

Alvin Bicker, Jr.

Bureau of Geology

P.O. Box 5348

Jackson, Mississ1ppi 39616

(601) $354-6228$

John Sonderegger

(406) 496-4151

Hydrothermal Division

Montana Bureau of Mines \& Geology

Butte, Montana 59701

(402) $472-3471$

Marvin Carlson

University of Nebraska at Lincoln

Conservation \& Survey Division

113 Nebraska Hall

Lincoln, Nebraska 68588

William Gosnold

University of Nebraska at Omaha

Department of Geography/Geology

UNO-Omaha, NE 68182

Dennis Trexler

Nevada Bureau of Mines \& Geology

University of Nevada-Reno

Reno, Nevada 89557

Same as Georgia

Larry Icerman

(505) 646-1745

New Mexico Energy Institute

P.0. Box 3EI

Las Cruces, New Mexico 88003

Burton Krakow

New York Energy Research and Development Authority

Agency B1dg. \#2

Rockefeller Plaza

Albany, New York 12223

James Dunn

(518) 783-8102

Dunn Geoscience Corporation

5 Northway Lane, $N$.

Latham, New York 12184

Same as Georgia
(702) 784-6691

(518) 465-6251 


\begin{tabular}{|c|c|c|c|}
\hline North Dakota & $\begin{array}{l}\text { Ken Harris } \\
\text { North Dakota Geological Survey } \\
\text { Box } 8103 \text {, University Station } \\
\text { Grand Forks, North Dakota } 58202\end{array}$ & $(701)$ & $777-2231$ \\
\hline Oklahoma & $\begin{array}{l}\text { William Harrison } \\
\text { Oklahoma Geological Survey } \\
\text { Room 163A } \\
830 \text { Van Vleet Oval } \\
\text { Norman, Oklahoma } 73019\end{array}$ & (405) & $325-3032$ \\
\hline Oregon & $\begin{array}{l}\text { Don Hull } \\
\text { Department of Geology \& Mineral } \\
\text { Industry } \\
1069 \text { State Office Bldg. } \\
\text { Portland, Oregon } 97201\end{array}$ & $(503)$ & $229-5580$ \\
\hline South Carolina & Same as Georgia & & \\
\hline South Dakota & $\begin{array}{l}\text { Duncan McGregor } \\
\text { South Dakota State Geological Survey } \\
\text { University of South Dakota } \\
\text { Vermillion, South Dakota } 57069\end{array}$ & $(605)$ & $624-4471$ \\
\hline Texas & $\begin{array}{l}\text { Charles Woodruff } \\
\text { Bureau of Economic Geology } \\
\text { University of Texas at Austin } \\
\text { University Station, Box X } \\
\text { Austin, Texas } 78712 \\
\text { C. D. Rao } \\
\text { TENRAC } \\
200 \text { East 18th Street } \\
\text { Room 505, ERS Bldg. } \\
\text { Austin, Texas } 78701\end{array}$ & $(512)$ & $475-5588$ \\
\hline & $\begin{array}{l}\text { Robert Roy } \\
\text { University of Texas } \\
\text { Department of Geological Science } \\
\text { E1 Paso, Texas } 79968\end{array}$ & $(915)$ & $747-5501$ \\
\hline Utah & $\begin{array}{l}\text { Wallace Gwynn } \\
\text { Utah Geological \& Mineral Survey } \\
606 \text { Black Hawk Way } \\
\text { Salt Lake City, Utah } 84108\end{array}$ & $(801)$ & $581-3068$ \\
\hline Virginia & Same as Georgia & & \\
\hline Washington & $\begin{array}{l}\text { Eric Schuster } \\
\text { Department of Natural Resources } \\
\text { Division of Geology and } \\
\text { Earth Resources } \\
\text { olympia, Washington } 98504\end{array}$ & (206) & $754-1616$ \\
\hline West Virginia & Same as Georgia & & \\
\hline Wyoming & $\begin{array}{l}\text { Henry Heasler } \\
\text { Department of Geology } \\
\text { University of Wyoming } \\
\text { P.0. Box } 3006 \\
\text { Laramie, Wyoming } 82071\end{array}$ & (307) & $766-3278$ \\
\hline
\end{tabular}

\section{General Information Concerning Resources}

East of Mississippi River - Joel Renner (Gruy Federal) - (703) 892-2700

West of Mississippi River - Duncan Foley (Earth Science Lab, UURI) - (801) 581-3155 